medRxiv preprint doi: https://doi.org/10.1101/2021.08.21.21262399; this version posted August 23, 2021. The copyright holder for this preprint (which was not certified by peer review) is the author/funder, who has granted medRxiv a license to display the preprint in perpetuity.

It is made available under a CC-BY-NC-ND 4.0 International license .

\title{
Integrated immune networks in SARS-CoV-2 infected pregnant women reveal differential NK cell and unconventional $T$ cell activation
}

Jennifer $R$ Habel $^{1}$, Brendon $\mathrm{Y}$ Chua ${ }^{1,2}$, Lukasz Kedzierski ${ }^{1,3}$, Kevin J Selva ${ }^{1}$, Timon Damelang ${ }^{1}$, Ebene R Haycroft ${ }^{1}$, Thi HO Nguyen ${ }^{1}$, Hui-Fern Koay ${ }^{1}$, Suellen Nicholson ${ }^{4}$, Hayley McQuilten ${ }^{1}$, Xiaoxiao Jia ${ }^{1}$, Lilith F Allen ${ }^{1}$, Luca Hensen ${ }^{1}$, Wuji Zhang ${ }^{1}$, Carolien E van de Sandt ${ }^{1}$, Jessica A Neil ${ }^{1}$, Fatima Amanat ${ }^{5,6}$, Florian Krammer $^{5}$, Kathleen Wragg ${ }^{1}$, Jennifer A Juno ${ }^{1}$, Adam K Wheatley ${ }^{1,}{ }^{7}$, Hyon-Xhi Tan ${ }^{1}$, Gabrielle Pell ${ }^{8}$, Jennifer Audsley ${ }^{9}$, Irani Thevarajan $^{9,10}$, Justin Denholm ${ }^{9,10}$, Kanta Subbarao ${ }^{1,11}$, Dale I Godfrey ${ }^{1}$, Allen C Cheng ${ }^{12,13}$, Steven YC Tong ${ }^{10,14}$, Katherine Bond ${ }^{1,15}$, Deborah A Williamson ${ }^{1,15}$, Fiona James ${ }^{16}$, Natasha E Holmes ${ }^{16-19}$, Olivia C Smibert ${ }^{16,20,21}$, Jason A Trubiano ${ }^{19-22}$, Claire L Gordon ${ }^{1,16}$, Amy W Chung ${ }^{1}$, Clare L Whitehead ${ }^{23,24}$, Stephen J Kent ${ }^{1,7,25}$, Martha Lappas ${ }^{8,26}$, Louise C Rowntree ${ }^{1 \#}$ and Katherine Kedzierska ${ }^{1,2 \#}$

${ }^{1}$ Department of Microbiology and Immunology, University of Melbourne, at the Peter Doherty Institute for Infection and Immunity, Melbourne, Victoria 3000, Australia;

${ }^{2}$ Global Station for Zoonosis Control, Global Institution for Collaborative Research and Education (GI-CoRE), Hokkaido University, Sapporo, Japan;

${ }^{3}$ Faculty of Veterinary and Agricultural Sciences, University of Melbourne, Melbourne, Victoria 3000, Australia;

${ }^{4}$ Victorian Infectious Diseases Reference Laboratory, The Royal Melbourne Hospital at The Peter Doherty Institute for Infection and Immunity, Melbourne, Victoria 3000, Australia;

${ }^{5}$ Department of Microbiology, Icahn School of Medicine at Mount Sinai, New York, NY, USA;

${ }^{6}$ Graduate School of Biomedical Sciences, Icahn School of Medicine at Mount Sinai, New York, NY, USA;

${ }^{7} A R C$ Centre of Excellence in Convergent Bio-Nano Science and Technology, University of Melbourne, Melbourne, Victoria 3000, Australia;

${ }^{8}$ Mercy Perinatal Research Centre, Mercy Hospital for Women, Heidelberg, Victoria 3084,

Australia;

${ }^{9}$ Department of Infectious Diseases, University of Melbourne at the Peter Doherty Institute for Infection and Immunity, Melbourne, Victoria 3000, Australia;

${ }^{10}$ Victorian Infectious Diseases Service, The Royal Melbourne Hospital at the Peter Doherty Institute for Infection and Immunity, Melbourne, Victoria 3000, Australia;

${ }^{11}$ World Health Organisation (WHO) Collaborating Centre for Reference and Research on Influenza, at The Peter Doherty Institute for Infection and Immunity, Melbourne, Victoria 3000 , Australia;

${ }^{12}$ School of Public Health and Preventive Medicine, Monash University, Melbourne, Victoria, Australia;

${ }^{13}$ Infection Prevention and Healthcare Epidemiology Unit, Alfred Health, Melbourne, Victoria, Australia;

${ }^{14}$ Menzies School of Health Research and Charles Darwin University, Darwin, Northern Territory, Australia;

${ }^{15}$ Department of Microbiology, Royal Melbourne Hospital, at The Peter Doherty Institute for Infection and Immunity, Melbourne, Victoria 3000, Australia;

${ }^{16}$ Department of Infectious Diseases, Austin Health, Heidelberg, Victoria 3084, Australia;

${ }^{17}$ Department of Critical Care, University of Melbourne, Parkville, Victoria 3000, Australia;

${ }^{18}$ Data Analytics Research and Evaluation (DARE) Centre, Austin Health and University of Melbourne, Heidelberg, Victoria 3084, Australia;

${ }^{19}$ Centre for Antibiotic Allergy and Research, Department of Infectious Diseases, Austin Health, Heidelberg, Victoria 3084, Australia;

${ }^{20}$ Department of Infectious Diseases, Peter McCallum Cancer Centre, Melbourne, Victoria 3000, Australia;

${ }^{21}$ National Centre for Infections in Cancer, Peter McCallum Cancer Centre, Melbourne, Victoria 3000, Australia; 
medRxiv preprint doi: https://doi.org/10.1101/2021.08.21.21262399; this version posted August 23, 2021. The copyright holder for this preprint (which was not certified by peer review) is the author/funder, who has granted medRxiv a license to display the preprint in perpetuity. It is made available under a CC-BY-NC-ND 4.0 International license.

${ }^{22}$ Department of Medicine (Austin Health), University of Melbourne, Heidelberg, Victoria 3084, Australia;

${ }^{23}$ Department of Obstetrics and Gynaecology, University of Melbourne, Parkville, Victoria

3052, Australia;

${ }^{24}$ Pregnancy Research Centre, The Royal Women's Hospital, Parkville, Victoria, Australia;

${ }^{25}$ Melbourne Sexual Health Centre, Infectious Diseases Department, Alfred Health, Central Clinical School, Monash University, Melbourne, Victoria, Australia;

${ }^{26}$ Obstetrics, Nutrition and Endocrinology Group, Department of Obstetrics and

Gynaecology, University of Melbourne, Victoria, Australia.

\#Authors contributed equally to this study.

Correspondence: kkedz@unimelb.edu.au

Running title: Immune responses to COVID-19 in pregnancy 
medRxiv preprint doi: https://doi.org/10.1101/2021.08.21.21262399; this version posted August 23, 2021. The copyright holder for this preprint (which was not certified by peer review) is the author/funder, who has granted medRxiv a license to display the preprint in perpetuity.

It is made available under a CC-BY-NC-ND 4.0 International license .

\begin{abstract}
Although pregnancy poses a greater risk for severe COVID-19, the underlying immunological changes associated with SARS-CoV-2 infection during pregnancy are poorly understood. We defined immune responses to SARS-CoV-2 in pregnant and non-pregnant women during acute and convalescent COVID-19 up to 258 days post symptom onset, quantifying 217 immunological parameters. Additionally, matched maternal and cord blood were collected from COVID-19 convalescent pregnancies. Although serological responses to SARS-CoV-2 were similar in pregnant and non-pregnant women, cellular immune analyses revealed marked differences in key NK cell and unconventional $\mathrm{T}$ cell responses during COVID-19 in pregnant women. While NK cells, $y \delta$ T cells and MAIT cells displayed preactivated phenotypes in healthy pregnant women when compared to non-pregnant agematched women, activation profiles of these pre-activated NK and unconventional T cells remained unchanged at acute and convalescent COVID-19 in pregnancy. Conversely, activation dynamics of $\mathrm{NK}$ and unconventional $\mathrm{T}$ cells were prototypical in non-pregnant women in COVID-19. In contrast, activation of $\alpha \beta \mathrm{CD}^{+}$and $\mathrm{CD} 8^{+} \mathrm{T}$ cells, $\mathrm{T}$ follicular helper cells and antibody-secreting cells was similar in pregnant and non-pregnant women with COVID-19. Elevated levels of IL-1 $\beta$, IFN- $\gamma$, IL-8, IL-18 and IL-33 were also found in pregnant women in their healthy state, and these cytokine levels remained elevated during acute and convalescent COVID-19. Collectively, our study provides the first comprehensive map of longitudinal immunological responses to SARS-CoV-2 infection in pregnant women, providing insights into patient management and education during COVID-19 pregnancy.
\end{abstract}


medRxiv preprint doi: https://doi.org/10.1101/2021.08.21.21262399; this version posted August 23, 2021. The copyright holder for this preprint (which was not certified by peer review) is the author/funder, who has granted medRxiv a license to display the preprint in perpetuity. It is made available under a CC-BY-NC-ND 4.0 International license .

\section{INTRODUCTION}

Severe acute respiratory syndrome coronavirus 2 (SARS-CoV-2) emerged in late 2019, causing a pandemic that has resulted in hundreds of million infections and $>4$ million deaths globally (Dong et al., 2020). As COVID-19 case numbers continue to rise, understanding immune responses to SARS-CoV-2, especially in high-risk groups, is of critical importance to guide treatment and vaccine strategies. The majority of immunological studies on COVID-19 have largely focused on the correlates of disease severity in previously healthy individuals across different age groups (Juno et al., 2020c; Koutsakos et al., 2021; Thevarajan et al., 2020). Most COVID-19 patients develop prototypical broad, robust and transient anti-viral immune responses to SARS-CoV-2 infection (Koutsakos et al., 2021; Kuri-Cervantes et al., 2020; Laing et al., 2020; Long et al., 2020; Mathew et al., 2020; Thevarajan et al., 2020), with abundant SARS-CoV-2-specific antibodies, B cell and T cell responses (Amanat et al., 2020; Grifoni et al., 2020; Habel et al., 2020; Juno et al., 2020b; Weiskopf et al., 2020), establishing long-lasting memory (Nguyen et al., 2014; Nguyen et al., 2021; Rodda et al., 2021; Rowntree et al., 2021; Wheatley et al., 2021). Hyperactivation of innate and adaptive immune responses as well as blood hypercytokinemia are characteristic of severe disease (Koutsakos et al., 2021; Kuri-Cervantes et al., 2020; Lucas et al., 2020; Mathew et al., 2020). There is, however, still a paucity of data on immune responses to SARS-CoV-2 infection in groups vulnerable to poor outcomes following infection, especially pregnant women.

Pregnant women are considered to be a vulnerable group for SARS-CoV-2 infection due to physiological and immunological changes occurring during gestation (Zambrano et al., 2020). Studies to date associate COVID-19 during pregnancy with an increased risk of intensive care unit (ICU) admission, invasive ventilation and extracorporeal membrane oxygenation (ECMO) compared to non-pregnant women of reproductive age (Allotey et al., 2020; Zambrano et al., 2020). In comparison to non-pregnant women with COVID-19, pregnant women with COVID-19 are at an increased risk of death, sepsis, mechanical ventilation, ICU admission, shock, acute renal failure and thromboembolic disease (Ko et al., 2021). Additionally, COVID-19 during pregnancy has been linked to an increased risk of preeclampsia and gestational hypertension, resulting in a greater risk of adverse pregnancy outcomes (Papageorghiou et al., 2021). Nonetheless, others have shown that pregnant women commonly have mild or asymptomatic SARS-CoV-2 infection (Crovetto et al., 2020). Pregnancy presents unique physiological and immunological states which are required to maintain a viable and healthy fetus, while still protecting the mother from infections. Gestational immune alterations can impair anti-viral responses, leading to severe disease such as that observed in the 1918, 1957 and 2009 influenza pandemics (Creanga et al., 2010; Eickhoff et al., 1961; Harris, 1919; Louie et al., 2010; Siston et al., 2010).

To date, published evidence shows that pregnant women who had COVID-19 produced SARS-CoV-2-specific antibodies, of which SARS-CoV-2-specific IgG antibodies were transferred to the cord blood (Atyeo et al., 2021; Edlow et al., 2020; Jang et al., 2021; Wang et al., 2021). A systematic review of clinical laboratory findings determined that a low white blood cell count was the only significant difference between the pregnant and nonpregnant COVID-19 immune responses (Areia and Mota-Pinto, 2020). However, pregnant or post-partum women who had recovered from COVID-19 had lower T follicular helper type 17 cells $\left(\mathrm{T}_{\mathrm{FH}} 17\right)$, memory B cells, total and 'virus'-specific $\left(\mathrm{CD} 56^{+} \mathrm{NKP} 46^{+}\right)$NK cells compared to healthy pregnant women (Zhao et al., 2021). Cytokine profiles differed between healthy pregnant women and those with COVID-19 (Chen et al., 2021; Zhao et al., 2021). Despite reports to date on specific immune parameters, a comprehensive analysis of immune perturbations in early and late stages of COVID-19 during pregnancy is lacking.

Our present study fills this knowledge gap and investigates the breadth of innate, adaptive and humoral immune responses to SARS-CoV-2 infection in pregnant women. Additionally, cord blood from convalescent COVID-19 pregnancies was assessed for SARSCoV-2-specific antibodies, and placenta cellular compartments were examined for differential immune cell activation in COVID-19 and healthy pregnancies. We recruited 101 
medRxiv preprint doi: https://doi.org/10.1101/2021.08.21.21262399; this version posted August 23, 2021. The copyright holder for this preprint (which was not certified by peer review) is the author/funder, who has granted medRxiv a license to display the preprint in perpetuity.

It is made available under a CC-BY-NC-ND 4.0 International license .

women to define immune responses to SARS-CoV-2 in pregnant and non-pregnant women during acute and convalescent COVID-19 up to 258 days post-disease onset, quantifying 217 immunological parameters. We provide the first comprehensive map of longitudinal immunological responses in COVID-19 pregnant women during acute and convalescent phases of SARS-CoV-2 infection. Our longitudinal comparisons revealed specifically lack of Y $\delta \mathrm{T}$ cell, MAIT and NK cell activation in pregnant women during acute COVID-19, as a result of their pre-activated profile during the healthy state. In contrast, activation of classical $\alpha \beta \mathrm{CD}^{+}$and $\mathrm{CD}^{+} \mathrm{T}$ cells, $\mathrm{T}$ follicular helper cells $\left(\mathrm{T}_{\mathrm{FH}}\right)$, antibody-secreting cells (ASC) and SARS-CoV-2-specific antibody patterns were similar across the groups. Differences in IL-1 $\beta$, IFN-y, IL-8, IL-18 and IL-33 levels were evident in a healthy state in pregnancy, and these cytokines remained elevated during acute and convalescent COVID-19. Taken together, our comprehensive analysis of immune dysfunction following COVID-19 in pregnancy provides key insights which can potentially inform patient management and education during COVID19 in pregnancy.

\section{RESULTS \\ COVID-19 pregnancy cohort demographics and study design}

We recruited a total of 101 women into our study to understand cellular and humoral immune responses to SARS-CoV-2 during pregnancy (Fig 1A, Supp Table 1 and 2). Blood samples were collected from 19 pregnant women with PCR-confirmed COVID-19 during their pregnancy; 8 pregnant women with acute COVID-19 (<21 days post symptom onset) and 13 pregnant women at convalescence ( $\geq 21$ days post symptom onset). As controls, blood samples were collected from 21 healthy pregnant women with no history of COVID-19. To define any alterations in the immune response to COVID-19 during pregnancy, we recruited 25 non-pregnant women with acute or convalescent PCR-confirmed COVID-19, and 37 healthy non-pregnant women (Fig 1A). Similar proportions of pregnant and nonpregnant women were located at home ( $50.0 \%$ vs $61.5 \%$, respectively), in the hospital ward $(45.0 \%$ vs $30.8 \%$, respectively) or in the intensive care unit (ICU; $5.0 \%$ vs $7.7 \%$, respectively) (Fig 1B). Pregnant women with acute or convalescent COVID-19 were recruited between $1-258$ days post symptom onset, with $47 \%(n=9)$ and $53 \%(n=10)$ being in their second or third trimester, respectively (Fig 1C). Non-pregnant women with COVID-19 were recruited between 2-205 days post symptom onset (Fig 1D). There were no significant differences in the days post symptom onset at sample collection between acute pregnant and non-pregnant groups (median of 8 and 8.5 days, respectively) and convalescent pregnant and non-pregnant groups (median of 107 and 86 days, respectively) (Fig 1E). The ages of pregnant and non-pregnant women in the healthy, acute or convalescent groups were similar, ranging from 20-49 years (Fig 1F). The average gestation of pregnant women with COVID-19 was comparable to healthy pregnant women (Fig $1 \mathrm{G}$ ).

Matched maternal blood, cord blood and placenta tissue were collected at the birth time-point in a subset of COVID-19 $(n=9)$ and SARS-CoV-2 unexposed $(n=6)$ pregnancies (Supp Table 2). Of the 9 COVID-19 pregnancies, 3 were admitted to hospital and 6 were at home during their acute disease (Fig $1 \mathrm{H})$. The ages of women with COVID-19 or unexposed pregnancy were not statistically different (Fig 1I). The gestational age at which COVID-19 was diagnosed ranged from 4-34 weeks, with $33.3 \%(n=3), 44.4 \%(n=4)$ and $22.2 \%(n=2)$ in the first, second or third trimester, respectively (Fig 1J). Additionally, 12 non-matched cord blood samples from healthy pregnancies formed a control group.

\section{Comparable RBD-specific and neutralizing antibodies in pregnant and non-pregnant women}

As SARS-CoV-2 antibodies are associated with protection from repeated infection (Harvey et al., 2021), we assessed humoral responses to SARS-CoV-2 in pregnant and nonpregnant women through the detection of RBD-specific $\lg$, $\lg M$ and $\lg A$ antibodies by ELISA (Amanat et al., 2020; Koutsakos et al., 2021; Rowntree et al., 2021) (Fig 2A-F), while the surrogate virus neutralization assay (sVNT) was used to measure neutralizing activity of 
medRxiv preprint doi: https://doi.org/10.1101/2021.08.21.21262399; this version posted August 23, 2021. The copyright holder for this preprint (which was not certified by peer review) is the author/funder, who has granted medRxiv a license to display the preprint in perpetuity. It is made available under a CC-BY-NC-ND 4.0 International license.

SARS-CoV-2-specific antibodies in COVID-19 patients (Nicholson et al., 2021; Rowntree et al., 2021; Tan et al., 2020) (Fig 2G). Overall, we detected no differences in the titres of RBDspecific $\lg G$, IgM or $\lg A$ between pregnant and non-pregnant women with acute or convalescent COVID-19 (Fig 2B). Similarly, no significant differences in the avidity of RBD$\lg G$ and RBD-lgM antibodies were found between pregnant and non-pregnant women when a urea-mediated dissociation ELISA was performed for donors who were bled sequentially (Fig 2C). Similar proportions of pregnant and non-pregnant donors seroconverted for IgG, $\lg$, IgA (Fig 2D), with the kinetics of RBD-lgG-specific titres also greatly overlapping (Fig $2 \mathrm{E})$. Importantly, there were no differences in the proportion of ACE2-RBD inhibition detected by sVNT between pregnant and non-pregnant women with acute or convalescent COVID-19 (Fig 2F). The similarity in antibody titres between pregnant and non-pregnant women demonstrates that the production of SARS-CoV-2-specific antibodies is not impaired during pregnancy, and importantly suggests that women who had COVID-19 during pregnancy generate humoral protection from future re-infections.

\section{Neutralizing antibodies, RBD- and N-specific IgGs cross placenta into cord blood}

Cord blood plasma from COVID-19 and SARS-CoV-2 unexposed pregnancies were assessed for neutralizing antibodies as well as RBD- and nucleocapsid (N)-specific lgM, IgG and $\lg \mathrm{A}$ antibodies. While $\mathrm{N}$-specific IgG titres were significantly increased in COVID-19 cord blood compared to healthy pregnancy cord blood, with $55.5 \%(n=5)$ of donors seroconverting (Fig 2G), 66.6\% ( $n=6)$ of COVID-19 cord blood donors seroconverted for RBD-IgG (Fig 2G). sVNT showed that the proportion of ACE2-RBD inhibition was similar between pregnant COVID-19 (mean 35.9\% inhibition), non-pregnant COVID-19 (mean 42.8\% inhibition) and COVID-19 cord blood (mean 38.2\% inhibition) (Fig 2H). Similar proportions of pregnant and non-pregnant donors were positive for the combined detection of RBD-specific antibodies and ACE2-RBD inhibition (27.8\% pregnant and $25.0 \%$ nonpregnant), with the majority of cord blood having RBD-IgG and/or neutralizing antibodies (77.8\%) (Fig 2I).

Comparisons between matched maternal-cord dyads clearly demonstrated that RBDand $\mathrm{N}$-specific IgG were elevated in cord blood plasma (Fig $2 \mathrm{H})$, which may be related to the preferential transfer of fucosylated IgG to cord blood (Atyeo et al., 2021). RBD-specific IgM and $\lg \mathrm{A}$ were also assessed in the cord blood (Supp Fig 1A), however, as these isotypes do not vertically transfer to the fetus, it was expected that these titres were significantly lower in the cord blood compared to maternal blood. Within COVID-19 pregnancy cord blood, RBDIgG titres strongly correlated with RBD-ACE2 inhibition ( $\left.r_{S}=0.9333 p=0.0007\right)$ determined by sVNT, and with $N$ - IgG titres $\left(r_{s}=0.9000, p=0.0020\right)$ (Fig 2J). Our findings verify reports by others that SARS-CoV-2 IgG antibodies (Atyeo et al., 2021; Edlow et al., 2020; Flannery et al., 2021) and neutralizing antibodies (Joseph et al., 2021; Malshe et al., 2021) cross the placenta, providing a layer of immunity against SARS-CoV-2 infection to the neonate.

Assessment of neutralizing antibodies by microneutralization assay confirmed that there were no differences between pregnant and non-pregnant women with acute or convalescent COVID-19 (Supp Fig 1B), and that neutralizing antibodies were detected in cord blood if the matched maternal blood was also positive (Supp Fig 1C).

Differential glycosylation patterns on total lgGs, based on the number of galactose $(G)$, sialic acid $(S)$ and fucose $(F)$ glycans, were detected in pregnant women, with G2S1F and G2F being significantly increased, while G0F, G1 and G1F were significantly reduced when comparing to non-pregnant women, with and without COVID-19 (Supp Fig 2). COVID19 pregnancy cord blood had increased G2 and decreased G2S1F compared to unexposed pregnancy cord bloods. (Edlow et al., 2020)

Overall, our in-depth analysis of antibody responses in COVID-19 pregnant women clearly demonstrated generation and persistence of RBD-specific $\lg$, $\lg M$ and $\lg A$ antibodies in pregnant women, their SARS-CoV-2 neutralisation activity, as well as provided evidence for RBD- and N-specific IgG antibodies found in the cord blood of convalescent mothers. 
medRxiv preprint doi: https://doi.org/10.1101/2021.08.21.21262399; this version posted August 23, 2021. The copyright holder for this preprint (which was not certified by peer review) is the author/funder, who has granted medRxiv a license to display the preprint in perpetuity.

It is made available under a CC-BY-NC-ND 4.0 International license .

\section{Systems serology reveals distinct antibody and Fcy receptor profiles between pregnant and non-pregnant women}

To further characterize in-depth SARS-CoV-2 specific antibody responses in pregnant and non-pregnant women as well as cord blood, a 102-parameter multiplex bead array was performed as previously described (Selva et al., 2021). A range of SARS-CoV-1 and SARSCoV-2 spike and nucleocapsid antigens were used for the detection of a range of epitopespecific antibody subclasses and isotypes (IgG1-4, $\lg A 1-2$ and $\lg M)$ and Fcy receptor binding (FcyRllaH, FcyRllaR, FcyRIlb, FcyRIIlaV, FcyRIllaF) (Supp Table 3). To determine the key features driving the separation between two groups, data were normalized before performing a LASSO-penalized logistic regression feature selection. To classify the individuals based on the selected features, principal component analysis (PCA) was performed.

A comparison between pregnant and non-pregnant women with acute COVID-19 revealed a clear separation between groups on PC1 (27.88\%) (Fig 3Ai). We identified fourteen features that contributed to the difference between pregnant and non-pregnant women with acute SARS-CoV-2 infection, twelve of which were biased towards the pregnant group with increased SARS-CoV-2 spike-head-specific IgA2, SARS-CoV-1 trimeric-spikespecific $\lg A 1, \lg A 2$, IgG2 and $\lg$ G4, SARS-CoV-1 nucleocapsid (NP)-specific IgA1, SARSCoV-2 trimeric-spike-specific IgG1 and IgM, RBD-specific IgM and IgG2, spike-stalk-specific IgG3 and FcyRIIlaV (Fig 3Aii). Whereas, non-pregnant women had increased SARS-CoV-2 trimeric-spike-specific FcyRIlb and SARS-CoV-1 trimeric-spike-specific IgG3 (Fig 3Aii).

To understand whether the serology features changed over time, we subsequently performed PCA on convalescent pregnant and non-pregnant donors (Fig 3B). Ten features were found to drive the difference between pregnant and non-pregnant women at convalescence (Fig 3Bii) and provided 37.34\% variance of groups on PC1 (Fig 3Bi). Among the features elevated in convalescent non-pregnant women, SARS-CoV-2 nucleocapsidspecific FcyRIIlaV and FcyRllb, RBD-specific FcyRIIlaV, spike-trimer-specific total IgG and SARS-CoV-1 nucleocapsid-specific IgG1 dominated (Fig 3Bii). In contrast, pregnant women displayed more spike-stalk-specific IgA2, SARS-CoV-2 RBD-specific IgG2 and FcyRllaR, spike-trimer-specific FcyRllb and SARS-CoV-1 nucleocapsid-specific IgG3.

As $\lg \mathrm{G}$, but not $\lg \mathrm{M}$ or $\lg \mathrm{A}$, is transferred across the placenta during gestation, our feature selection model of convalescent pregnant women and cord blood from COVID-19 pregnancies excluded $\lg \mathrm{M}$ and $\lg \mathrm{A}$ parameters to accurately reveal differences in virusspecific antibodies rather than their subclasses. PCA demonstrated that convalescent pregnant women and COVID-19 pregnancy cord blood were separated across PC1 (Fig 3Ci, Variance $54.10 \%$ ). Cord blood from COVID-19 pregnancies were enriched for IgG1 and FcyRIIlaV against SARS-CoV-1 or SARS-CoV-2 nucleocapsid protein, while convalescent pregnant women had elevated SARS-CoV-2 spike stalk and head-specific antibodies with the capacity to bind FcyRllaH (Fig 3Cii). Thus, our system serology approach revealed distinct antibody and Fcy receptor profiles between pregnant and non-pregnant women, as well as between pregnant women and COVID-19 cord blood.

\section{Similar frequencies of antibody-secreting cells, circulating $T_{F H}$ cells and monocytes in pregnant and non-pregnant COVID-19}

As $B$ cells are needed for antibody production, we determined B cell activation phenotypes by flow cytometry. Analysis of antibody-secreting cells (ASCs) defined as CD2 $7^{+} \mathrm{CD} 38^{+}$of the CD19+CD3 lymphocyte population (Fig 4A) showed comparable frequencies between pregnant and non-pregnant women with acute (mean $5.5 \%$ and $3.7 \%$, respectively) and convalescent (mean 1.0\% and 0.8\%, respectively) COVID-19 (Fig 4B). However, the mean fold-difference in the frequency of ASCs at the acute phase compared to healthy individuals was $\sim 6$-fold higher in pregnant women compared to a lower $\sim 2$-fold difference in nonpregnant women (Fig 4C), although ASCs displayed similar kinetics in both patient groups (Fig 4D). RBD-specific antibody titres and the frequency of ASCs did not correlate in either 
medRxiv preprint doi: https://doi.org/10.1101/2021.08.21.21262399; this version posted August 23, 2021. The copyright holder for this preprint (which was not certified by peer review) is the author/funder, who has granted medRxiv a license to display the preprint in perpetuity. It is made available under a CC-BY-NC-ND 4.0 International license.

pregnant or non-pregnant women with acute or convalescent COVID-19 (Fig 4E), similar to previous findings (Koutsakos et al., 2021; Kuri-Cervantes et al., 2020; Mathew et al., 2020).

Circulating $\mathrm{CXCR}^{+} \mathrm{T}$ follicular helper $\left(\mathrm{CT}_{\mathrm{FH}}\right) \mathrm{CD}^{+}{ }^{+} \mathrm{T}$ cells correlate with $\mathrm{B}$ cell maturation and activation (Koutsakos et al., 2018), therefore $\mathrm{cT}_{\mathrm{FH}}$ cells were assessed by flow cytometry, with activation defined as co-expression of PD-1 and ICOS (Fig 4F). No significant differences in the frequencies of PD- $1^{+} \mathrm{ICOS}^{+} \mathrm{CT}_{\mathrm{FH}}$ cells were observed between pregnant and non-pregnant women with acute or convalescent COVID-19 (Fig 4G). When $\mathrm{CT}_{\mathrm{FH}}$ cells were further defined into $\mathrm{CXCR}^{+} \mathrm{T}_{\mathrm{FH}}$ type $1\left(\mathrm{~T}_{\mathrm{FH}} 1\right)$ and $\mathrm{CXCR}^{-} \mathrm{T}_{\mathrm{FH}}$ type 2/17 $\left(\mathrm{CT}_{\mathrm{FH}} 2 / 17\right)$, the frequency of $\mathrm{PD}-1^{+} \mathrm{ICOS}^{+}$-activated $\mathrm{CT}_{\mathrm{FH}} 1$ cells was higher in convalescent pregnant versus non-pregnant women (mean $2.63 \%$ vs $0.96 \%$, respectively, $p<0.05$ ), however no differences were found for the acute or healthy groups (Fig 4H). Similar activation levels of the $\mathrm{CT}_{\mathrm{FH}} 2 / 17$ subset were observed in pregnant and non-pregnant women for each of the disease states (Fig 4I). There were no correlations between RBDspecific antibody titres and the frequency of activated $\mathrm{CT}_{\mathrm{FH}} 1$ or $\mathrm{CT}_{\mathrm{FH}} 2 / 17$ cells (Fig $4 \mathrm{~J}, \mathrm{~K}$ ).

Analysis of the myeloid compartment revealed no differences in monocyte subsets according to their CD14 and/or CD16 expression across healthy, COVID-19 acute or convalescent pregnant and non-pregnant women (Fig 4L,M). Therefore, our results highlight that pregnant woman can generate robust $A S C, T_{F H}$ and myeloid responses during acute COVID-19.

\section{Differential NK cell activation and cytotoxicity patterns in pregnant women during acute COVID-19}

Natural killer cells play an important role in anti-viral immunity, especially via mediating rapid killing of virally-infected cells. To determine activation of NK cells, CD3 ${ }^{-}{ }^{-} 56^{+}{ }^{+} \mathrm{NK}$ cells were

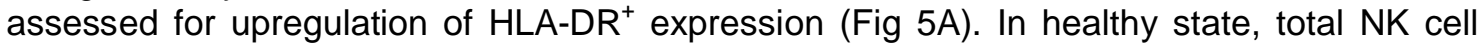
activation was significantly higher in healthy pregnant women when compared to nonpregnant women (mean $4.49 \%$ and $0.2 \%$, respectively, $p<0.0001$ ) consistent with previous work (Le Gars et al., 2019), indicating pre-activated NK cells during healthy pregnancy. Strikingly, activation profiles of these pre-activated NK cells remained unchanged at acute and convalescent COVID-19 in pregnancy (Fig 5B). In contrast to non-pregnant COVID-19 women, where NK cell activation during acute COVID-19 was driven by a $\sim 28$-fold increase in NK cell activation (as compared to healthy non-pregnant), NK activation in acute COVID19 pregnant women remained at the level observed in healthy pregnant participants (Fig 5C). Conversely, at convalescence, while the proportion of activated NK cells decreased in non-pregnant women with COVID-19, NK cell activation levels still remained high for at least $>100$ days post disease onset in convalescent COVID-19 pregnant women, similar to the high levels already observed for healthy and acute pregnant women. This was further evident from a significant negative correlation between the frequency of HLA-DR ${ }^{+} \mathrm{NK}$ cells and the day post symptom onset $\left(r_{s}=-0.5496, p=0.0294\right)$ in non-pregnant women, with no correlation observed in pregnant COVID-19 women (Fig 5D). Overall, our data reveal preactivated state of NK cells in healthy pregnancy as well as tightly regulated processes of NK activation above this pre-activated level, resulting in lack of further NK cell activation during acute COVID-19 in pregnancy.

To further delve into differential NK cell activation between pregnant and nonpregnant women, we differentiated the NK cell population into CD56 ${ }^{\text {bright }}$ CD $16^{\text {low/- }}$ and CD56 ${ }^{\text {dim }}$ CD $16^{+}$subsets. CD56 ${ }^{\text {bright }} \mathrm{NK}$ cells are functionally associated with cytokine production, whereas CD56 ${ }^{\mathrm{dim}}$ NK cells are cytotoxic (Caligiuri, 2008; Cooper et al., 2001). In each of the healthy or COVID-19 disease states, pregnant women had a significantly higher frequency of CD56 bright $\mathrm{NK}$ cells compared to non-pregnant women, while they had significantly lower frequencies of CD56 ${ }^{\text {dim }}$ NK cells during acute and convalescent COVID-19 (Fig 5E).

To assess the cytotoxic potential between the two $\mathrm{CD} 56^{\text {bright }} \mathrm{CD} 16^{\text {low/- }}$ and CD56 ${ }^{\text {dim }}$ CD $16^{+}$NK cell subsets, we performed intracellular staining for granzyme $A, B, K$ and $M$ as well as perforin. The majority of the total NK cell population expressed 3-5 cytotoxic granzymes or perforin in pregnant and non-pregnant women who were healthy or had acute 
medRxiv preprint doi: https://doi.org/10.1101/2021.08.21.21262399; this version posted August 23, 2021. The copyright holder for this preprint (which was not certified by peer review) is the author/funder, who has granted medRxiv a license to display the preprint in perpetuity. It is made available under a CC-BY-NC-ND 4.0 International license.

or convalescent COVID-19. CD56 dim NK cells largely expressed multiple cytotoxic molecules, fitting their previously defined cytotoxic function (Fig 5Fi). Conversely, CD56 bright NK cells displayed less multifunctionality overall, but interestingly, pregnant women with acute COVID-19 had the largest proportions of cells expressing 3-5 cytotoxic molecules, which might indicate increased cytotoxic potential of this classically non-cytotoxic NK cell subset during pregnancy (Fig 5Fii). This might provide a partial explanation on the need for a tight regulation of highly cytotoxic NK cells during COVID-19 in pregnant women.

\section{Differential $y \delta \mathrm{T}$ cell activation in pregnant women during COVID-19}

үठ T cells are an unconventional T cell subset which play an important role in anti-viral responses to respiratory diseases, including influenza (Sant et al., 2019) and COVID-19 (Jouan et al., 2020), however their role and activation status in COVID-19 pregnant women is not yet defined. We defined activation of $\gamma \delta$ T cells by HLA-DR and CD38 co-expression on $\mathrm{CD}^{+}{ }^{+} \overline{\mathrm{TTCR}}{ }^{+}$lymphocytes from peripheral blood (Fig $5 \mathrm{G}$ ). Similar to our findings in NK

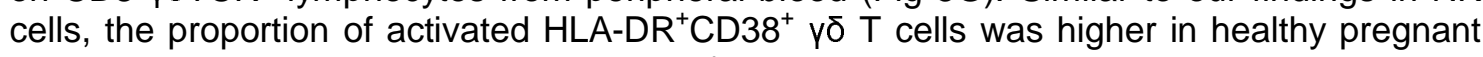
women compared to non-pregnant women (mean $4.4 \%$ and $1.1 \%$, respectively, $p<0.01$; Fig $5 \mathrm{H})$. Alternatively, during acute COVID-19, pregnant women had lower frequencies of activated $\gamma \delta$ T cells than non-pregnant women (mean $4.0 \%$ and $10.4 \%$, respectively, $p<0.05$; Fig $5 \mathrm{H}$ ). The activation of $\gamma \delta \mathrm{T}$ cells in pregnant women remained stable despite having acute COVID-19, whereas non-pregnant women with acute disease displayed an 8-fold increase in $\gamma \delta \mathrm{T}$ cell activation compared to healthy non-pregnant women (Fig $5 \mathrm{I})$. The frequency of $\mathrm{HLA}-\mathrm{DR}^{+} \mathrm{CD} 38^{+} \mathrm{y} \delta \mathrm{T}$ cells had a significant negative correlation with the day post symptom onset in non-pregnant women $\left(r_{s}=-0.7004, p=0.0012\right)$, however these two variables did not correlate for pregnant women (Fig $5 \mathrm{~J}$ ). Further probing of $\mathrm{HLA}^{-D R^{+} \mathrm{CD} 38^{+}}$ Y $\delta T$ cells revealed a similar distribution in the activation of the V $\delta 1$ or V $\delta 2$ subsets between pregnant and non-pregnant women (Fig 5K,L). However, during acute COVID-19, we observed that the Vס1 subset comprised a larger proportion of activated $ү \delta \bar{T}$ cells, which then decreased at convalescence for pregnant and non-pregnant women (Fig 5M). As Vס2 T cells are associated with their cytotoxic activity (Juno and Kent, 2020; Wragg et al., 2020), the decreased proportion in the blood during acute COVID-19 could be due to trafficking to the site of infection to perform effector functions.

It is important to note that while key differences in the activation of non-classical $y \delta T$ cells and NK cells were observed, similar activation patterns of classical $\alpha \beta \mathrm{CD}^{+}$and $\mathrm{CD} 8^{+}$ $T$ cell activation were detected in COVID-19 pregnant and non-pregnant women, suggesting that $\mathrm{T}$ cell receptor (TCR)-mediated $\mathrm{T}$ cell responses in the context of peptide/MHC presentation might not be affected by pregnancy (Supp Fig 3).

\section{Regulated activation of mucosal-associated invariant T (MAIT) cell responses in pregnant women during COVID-19}

Defined by their ability to recognize MR1 and expression of the Va7.2 TCR chain, MAIT cells represent another subset of unconventional $T$ cells and have an important role in anti-viral immunity, such as during influenza virus infection and COVID-19 (Flament et al., 2021; Jouan et al., 2020; Loh et al., 2016). While MAIT cells characteristically recognize riboflavin metabolites produced by bacterial biosynthesis pathways, they can be activated as a firstline of defence in a TCR-independent manner through cytokines, including IL-12 and IL-18 stimulation (Loh et al., 2016; Mayassi et al., 2021) . Our analysis revealed that healthy pregnant women had a lower frequency of MR1-5-OP-RU tetramer ${ }^{+}$Va7.2 $^{+}$MAIT cells compared to healthy non-pregnant women (Fig $5 \mathrm{~N}, \mathrm{O}$ ). Non-pregnant women displayed a decrease in the frequency of MAIT cells during acute COVID-19, however a further reduction from the healthy state was not observed in pregnant women, likely due to the already perturbed MAIT cell frequencies pre-COVID-19 (Fig 5O). However, further investigation of MAIT cell activation defined by the expression of HLA-DR and CD38 showed unchanged activation phenotype in pregnant women across disease stages, while non-pregnant women displayed increased activation during acute COVID-19 (Fig 5P,Q). 
medRxiv preprint doi: https://doi.org/10.1101/2021.08.21.21262399; this version posted August 23, 2021. The copyright holder for this preprint (which was not certified by peer review) is the author/funder, who has granted medRxiv a license to display the preprint in perpetuity.

It is made available under a CC-BY-NC-ND 4.0 International license .

Immune cell activation within the placenta is similar between COVID-19 convalescent and unexposed pregnancies

The placenta is the organ that forms the maternal-fetal interface and allows for exchange of nutrients and waste products to and from the fetus. There is limited evidence that SARSCoV-2 is able to cross the placenta, resulting in vertical transmission of the virus(Fenizia et al., 2020; Kotlyar et al., 2021). To assess for any lasting changes in cellular immune components within placental tissue, flow cytometry was performed on placenta single-cell suspensions from 9 COVID-19 convalescent and 6 SARS-CoV-2 unexposed pregnancies. There was no difference in total NK cell activation between COVID-19 and unexposed placenta samples (Supp Fig 4A), and a similar finding was observed in each of the CD56 bright and CD56 dim subsets (Supp Fig 4B,C). Contrary to observations in maternal blood at both acute and convalescent timepoints (Fig 5E), there were almost equivalent proportions of CD56 bright and CD56 ${ }^{\text {dim }}$ subsets comprising the placental NK cell population for healthy (mean $34.8 \%$ and $45.1 \%$, respectively) and COVID-19 convalescent pregnancies (mean $41.2 \%$ and $33.9 \%$, respectively, Supp Fig 4D). There were significantly higher frequencies of CD56 bright $\mathrm{NK}$ cells in the placenta tissue compared to matched maternal blood (mean $13.4 \%$ and $38.8 \%, p=0.0005$, Supp Fig 4E), typically observed in healthy pregnancies (Liu et al., 2021b). $\alpha \beta C D 4^{+}$and $C D 8^{+} T$ cells and $\gamma \delta$ T cells were also examined in the placenta for HLA-DR and CD38 expression to determine their activation. Similar to NK cells, there were no significant differences in the activation of these T cell subsets (Supp Fig 4F-H), indicating no lasting differential activation within the placenta at convalescence from COVID-19.

\section{Elevated levels of IL-1 $\beta$, IFN-y, IL-8, IL-18 and IL-33 in healthy pregnancy and during COVID-19}

As dysregulation of inflammatory cytokines and chemokines can be associated with severe COVID-19 (Koutsakos et al., 2021; Zhang et al., 2020), we assessed cytokine and chemokine profiles in our pregnancy cohort to understand whether the inflammatory response during COVID-19 differed between pregnant and non-pregnant women. As pregnant women are in a differential state of inflammation due to gestation, with relatively higher levels of IL-1 $\beta, \mathrm{IL}-4, \mathrm{IL}-5$ and IL-10 (Pinheiro et al., 2013), we hypothesised that this might impact cytokine and chemokine levels during acute COVID-19. Elevated levels of IL$1 \beta$, IFN- $\gamma$, IL-8, IL-18 and IL-33 were found in pregnant women in their healthy state, and these cytokine levels remained elevated during acute and convalescent COVID-19 (Fig 6A). In addition to differences in cytokine and chemokine levels individually, the total level of cytokines and chemokines measured was higher in pregnant women during each disease state (Fig 6B). Despite having a greater total concentration of cytokines and chemokines, pregnant women with acute COVID-19 had similar proportions of each cytokine in the plasma compared to healthy and convalescent samples (Fig 6C). Moreover, similar levels of cytokines were detected in cord blood from healthy and COVID-19 convalescent pregnancies (Supp Fig 5). Therefore, our data suggest that pregnant women do not make the same inflammatory COVID-19 response as non-pregnant women, as some cytokine levels are already high in healthy pregnancy, they fail to rise further during acute COVID-19 and then fail to decrease following SARS-CoV-2 infection.

\section{Immune network analysis reveals a comprehensive map of immune responses to COVID-19 in pregnancy}

We comprehensively analysed all the immunological parameters between pregnant and non-pregnant women, which included 217 datasets of antibodies, cellular subsets and cytokines/chemokines and revealed distinct profiles between pregnant and non-pregnant women (Fig 7A). While striking differences in immune responses were found between pregnant and non-pregnant women in the healthy state and convalescent COVID-19, immune responses were more comparable during acute COVID-19 (Fig 7B-D), which reflects the pre-activated and inflamed state in pregnant women. For example, in the healthy state, pregnant women displayed profound upregulation of $\mathrm{HLA}-\mathrm{DR} \mathrm{R}^{+} \mathrm{CD} 56^{\text {bright }} \mathrm{NK}$ cells, 
medRxiv preprint doi: https://doi.org/10.1101/2021.08.21.21262399; this version posted August 23, 2021. The copyright holder for this preprint (which was not certified by peer review) is the author/funder, who has granted medRxiv a license to display the preprint in perpetuity. It is made available under a CC-BY-NC-ND 4.0 International license .

$\mathrm{HLA}-\mathrm{R}^{+} \mathrm{CD} 38^{+}$y $\delta \mathrm{T}$ cells, IL-8, IL-10, and IL-18 (Fig 7B). These differences became less apparent during acute COVID-19, when pregnant women appeared to have prototypical antiviral immunity (Fig 7C). Thus, although the immune responses in pregnant women with acute COVID-19 closely resemble those in acute COVID-19 non-pregnant women, a lack of activation above the healthy baseline levels questions the quality of these responses. Conversely, at convalescence, hyperactivation of immune responses in pregnant women was again observed, especially with respect to cytokine production (IL-8, IL-10, IL-12, IL17a, IL-18, IL-23) and NK cell cytotoxicity (Fig 7D). Taken together, our study provides a comprehensive map of longitudinal immunological responses in COVID-19 pregnant women during acute and convalescent phases of SARS-CoV-2 infection and reveals pre-activated status of NK cells and unconventional T cells and elevated levels of cytokines in healthy pregnancy, which remained unchanged during acute and convalescent COVID-19.

\section{DISCUSSION}

Pregnant women are considered a vulnerable group for SARS-CoV-2 infection (Zambrano et al., 2020), as published reports correlated pregnancy with an increased risk of ICU admission, invasive ventilation, extracorporeal membrane oxygenation (ECMO) (Allotey et al., 2020; Zambrano et al., 2020), death, sepsis, mechanical ventilation, ICU admission, shock, acute renal failure and thromboembolic disease (Ko et al., 2021) and hypertensive complications (Papageorghiou et al., 2021). However, not all studies reveal strong correlations between pregnancy and COVID-19 severity or prolonged disease complications (Crovetto et al., 2020), and not at the level that occurred during the $2009 \mathrm{H} 1 \mathrm{~N} 1$ pandemic (Siston et al., 2010). As more epidemiological data regarding COVID-19 during pregnancy emerges, it is essential to comprehensively define immune responses to SARS-CoV-2 infection to understand whether SARS-CoV-2 immunity in pregnancy is prototypical and resembles immune responses of mild to moderate COVID-19 in non-pregnant individuals (Juno et al., 2020c; Koutsakos et al., 2021; Rowntree et al., 2021; Thevarajan et al., 2020; Wheatley et al., 2021), or in contrast, is characterised by immune perturbations similar to those observed during severe COVID-19 (Koutsakos et al., 2021; Lucas et al., 2020). Indepth dissection of immune responses in pregnant women is needed to provide insights into the immunological basis underlying COVID-19 outcomes. Our study fills this knowledge gap and provides the first comprehensive map of longitudinal immunological responses in COVID-19 pregnant women during acute and convalescent phases of SARS-CoV-2 infection. We investigated the breadth of 217 cellular and humoral immune parameters in pregnant women, as well as immune responses in cord blood and placenta from COVID-19 pregnancies. To the best of our knowledge, this is the first study providing an integrated comprehensive dataset on innate, adaptive and cellular immune networks to SARS-CoV-2 infection in pregnant women.

Importantly, our in-depth analysis of the antibody response in COVID-19 pregnant women via elucidating RBD-specific $\lg G \lg M$ and $\lg A$, their neutralising activity, multidimensional system serology parameters together with ASCs and $T_{F H}$ cells showed comparable antibody features between COVID-19 pregnant and non-pregnant women during acute and convalescent SARS-CoV-2 infection. Our analyses of humoral immune responses to SARS-CoV-2 in pregnancy clearly demonstrated generation and persistence of RBD-specific $\lg$, IgM and $\lg A$ antibodies in pregnant women, and their SARS-CoV-2 neutralisation activity, together with rapid induction of $A S C$ and $T_{F H}$ cells. We also provided evidence of RBD- and N-specific IgG antibodies found in the cord blood of convalescent mothers. Our data validates previous studies showing generation of SARS-CoV-2-specific antibodies in pregnant women (Atyeo et al., 2021; Edlow et al., 2020; Jang et al., 2021; Wang et al., 2021).

Our longitudinal comparisons of cellular immunity in COVID-19 revealed prototypical activation patterns of classical $\alpha \beta \mathrm{CD}^{+}$and $\mathrm{CD}^{+}{ }^{+} \mathrm{T}$ cells but differential and $\mathrm{NK}$ cell and unconventional $\mathrm{T}$ cell activation in pregnant women during acute COVID-19, with NK cells expressing increased frequency of CD56 ${ }^{\text {bright }}$ NK cells and multiple cytotoxic molecules. Differential immune responses by NK cells have been previously reported in the literature in 
medRxiv preprint doi: https://doi.org/10.1101/2021.08.21.21262399; this version posted August 23, 2021. The copyright holder for this preprint (which was not certified by peer review) is the author/funder, who has granted medRxiv a license to display the preprint in perpetuity. It is made available under a CC-BY-NC-ND 4.0 International license .

healthy pregnant women and in the context of influenza(Kay et al., 2014; Le Gars et al., 2019), however $\gamma \delta \mathrm{T}$ cell and MAIT activation in pregnancy is not well understood. It was recently reported that healthy pregnant women in their second or third trimester have increased frequencies of a yo T cell subset characterised by CD56 expression and higher cytotoxic potential reflected by expression of CD107a, in comparison to non-pregnant women(Nörenberg et al., 2021). Additionally, women who were previously pregnant had substantially increased frequencies of PD $-1^{+} \mathrm{V} \delta 2^{+} y \delta \mathrm{T}$ cells compared to nulliparous women or women with recurrent pregnancy loss (Liu et al., 2021a). Furthermore, an enrichment of Vס1 and HLA-DR ${ }^{+}$y $\delta ~ T$ cells have been observed in the decidua during early pregnancy(Terzieva et al., 2019). These reports suggest an important role for $\gamma \delta$ T cells in pregnancy, but their function and mechanisms in this state remain unknown.

While striking differences in MAIT and $\gamma \delta$ T cell, and NK cell responses were found between pregnant and non-pregnant women in healthy and/or convalescent COVID-19 states, immune responses appeared reasonably comparable during acute COVID-19. As a result, there was no increased activation of $\gamma \delta$ T cell and NK cell above the 'baseline' healthy pregnant levels, and no further decrease in the frequencies of peripheral blood MAIT cells. As anti-viral immune responses are multifactorial, further studies performed in $\gamma \delta \mathrm{T}$ cell and NK cell knockout mice during SARS-CoV-2 infection are needed to fully understand the impact of differential NK cell and $\gamma \delta$ T cell activation in the context of COVID-19.

IL-1 $\beta$, IFN- $\gamma$, IL-8, IL-18 and IL-33 were increased in healthy pregnant women and during acute and convalescent COVID-19. Interestingly, IL-18 dependent MAIT cell activation has been reported in the context of influenza infection (Loh et al., 2016), which might suggest a role for IL-18 in mediating MAIT cell activation during pregnancy as it was found at increased concentrations in our analysis. There are limited studies that compare cytokine levels between healthy pregnant and non-pregnant women to define a common cytokine profile associated with pregnancy. However, Pinheiro et al. (2013) showed that pregnant women have an increased frequency of regulatory cytokines, including IL-1 $\beta, I L-4$, IL-5 and IL-10, compared to non-pregnant women. Furthermore, in a comparison of cytokine levels during pregnancy and at one-year post-partum, Graham et al. (2017) found that pro-inflammatory IL-18, TNFa and MCP-1 were reduced during pregnancy while IL-10 remained unchanged. Pregnant women with COVID-19 shared similar cytokine and chemokine profiles as non-pregnant women, with the exception of eotaxin and GRO-a, while key differences between COVID-19 and healthy pregnant women have been observed in IL12p70, MIP-1 $\beta$, RANTES (Chen et al., 2021; Zhao et al., 2021). Our analysis showed that IL-18 was elevated during pregnancy regardless of disease state, which has been shown to cause TCR-independent activation of MAIT cells (Loh et al., 2016). It would be of value to further investigate if the pre-activated phenotype observed in MAIT cells of pregnant women could be related to the increased concentration of this cytokine in the blood plasma.

Our analyses of immune cell populations within placenta tissues from COVID-19 or healthy pregnancies revealed comparable levels of activation in NK and T cell subsets. The similarities between healthy and COVID-19 placenta immune cell activation might be due to COVID-19 pregnant women being at convalescence. However, a recent study examining placenta histological features from women acutely infected with SARS-CoV-2 at the time of birth found no significant differences in placental histopathologies, suggesting that COVID19 does not directly affect inflammation at the maternal-fetal interface (Tasca et al., 2021).

Overall, our immune landscape data provide evidence that while the antibody and cellular components remain similar in pregnant and non-pregnant COVID-19 women during acute and convalescent phases of SARS-CoV-2 infection, perturbations of NK cell and unconventional $\mathrm{T}$ cell levels and inflammation are observed, providing key insights into further studies of immune responses in pregnancy. Our data will help inform patient management and education of COVID-19 during pregnancy.

\section{ACKNOWLEDGMENTS}


medRxiv preprint doi: https://doi.org/10.1101/2021.08.21.21262399; this version posted August 23, 2021. The copyright holder for this preprint (which was not certified by peer review) is the author/funder, who has granted medRxiv a license to display the preprint in perpetuity.

It is made available under a CC-BY-NC-ND 4.0 International license .

We thank all the participants involved in the study; Jeni Mitchell, Zelda Williams, Veronica Link, Beverly Cox, Robyn Esterbauer, Hannah Kelly, Jane Batten and Helen Kent for support with the cohort; Jill Garlick, Janine Roney, Anne Paterson and the research nurses at the Alfred Hospital. We acknowledge all DRASTIC (The use of cytokines as a preDictoR of disease Severity in criTically III Covid-patients) investigators from Austin Health, and thank the participants involved. The authors thank Effie Mouhtouris and Ana Copaescu for laboratory work and study coordination for the DRASTIC study, and George Drewett for patient recruitment. This research included samples and data from the Sentinel Travelers Research Preparedness Platform for Emerging Infectious Diseases (SETREP-ID). We acknowledge all SETREP-ID investigators and sites, and thank all participants involved. The authors thank Barbara Scher for setting up the ethics and governance for the SETREP-ID platform and the Australian Partnership for Preparedness Research for Infectious Disease Emergencies (APPRISE) for ongoing funding of SETREP-ID, Ajantha Rhodes, Judy Chang, Ashanti Dantanarayana and Rosalyn Cao who contributed to the SETREP-ID biobank. SETREP-ID is supported by funding through the National Health and Medical Research Council Centre of Research Excellence (NHMRC CRE), the Australian Partnership for Preparedness Research on Infectious Disease Emergencies (APPRISE AppID 1116530), the Snow Medical Foundation, the Jack Ma Foundation and the A2 Milk Company. We thank Leo Lee and Francesca Mordant for their assistance with the MN assays. This work was supported by the Australian National Health and Medical Research Council (NHMRC) Leadership Investigator Grant to KK (\#1173871), Research Grants Council of the Hong Kong Special Administrative Region, China (\#T11-712/19-N) to KK, the Jack Ma Foundation to KK, KS, DIG, IT and AWC, the Victorian Government MRFF award (\#2002073) to SJK, DIG and AWC, MRFF Award (\#1202445) to KK, MRFF Award (\#2005544) to KK, SJK, AWC, ACC, DW and JAJ, NHMRC program grant 1149990 (SJK), NHMRC Program Grant (1113293) to DIG. THON was supported by a NHMRC Emerging Leadership Level 1 Investigator Grant (\#1194036), HFK, CLG and JAT by NHMRC Early Career Fellowships (\#1160333, \#1160963 and \#1139902), KS by a NHMRC Investigator grant (\#1177174), DIG by a NHMRC Senior Principal Research Fellowship (\#1117766), AWC by an NHMRC Career Development Fellowship (\#1140509) and SJK by NHMRC Senior Principal Research Fellowship (\#1136322). JRH, LH and WZ are supported by the Melbourne International Research Scholarship (MIRS) and the Melbourne International Fee Remission Scholarship (MIFRS) from The University of Melbourne. XJ was supported by China Scholarship Council-University of Melbourne joint Scholarship. JAJ is supported by an NHMRC Early Career Fellowship (ECF) (\#1123673). KK and AWC were supported by the University of Melbourne Dame Kate Campbell Fellowship. The Melbourne WHO Collaborating Centre for Reference and Research on Influenza is supported by the Australian Government Department of Health.

\section{AUTHOR CONTRIBUTIONS}

$\mathrm{KK}$ and LCR supervised the study. KK, LCR, JRH, BYC, LK, HK, SN and AWC designed the experiments. JRH, BYC, LK, KJS, TD, ERH, THON, HK, SN, XJ, LFA, LH, WZ, CES, JAN, $H T$ and LCR performed and analysed experiments. TD, LH and HM analysed data. FA, FK and AKW provided reagents. KW, JAJ, AKW, GP, JA, IT, JD, ACC, SYCT, KB, DAW, FJ, $\mathrm{NEH}, \mathrm{OCS}, \mathrm{JAT}, \mathrm{CLG}, \mathrm{CLW}$, SJK and ML recruited the patient cohorts and provided clinical data. JRH, SN, KS, DIG, AWC, SJK, ML, LCR and KK provided intellectual input into the study design and data interpretation. JRH, LCR and KK wrote the manuscript. All authors reviewed and approved the manuscript.

\section{DATA AVAILABILITY}

The source data underlying Figures and Supplementary Figures will be provided as Source Data. Raw FACS data are shown in the manuscript. FACS-source files are available from the authors upon request. 
medRxiv preprint doi: https://doi.org/10.1101/2021.08.21.21262399; this version posted August 23, 2021. The copyright holder for this preprint (which was not certified by peer review) is the author/funder, who has granted medRxiv a license to display the preprint in perpetuity.

It is made available under a CC-BY-NC-ND 4.0 International license .
. 
medRxiv preprint doi: https://doi.org/10.1101/2021.08.21.21262399; this version posted August 23, 2021. The copyright holder for this preprint (which was not certified by peer review) is the author/funder, who has granted medRxiv a license to display the preprint in perpetuity. It is made available under a CC-BY-NC-ND 4.0 International license.

\section{METHODS}

Study participants and ethics statement.

86 subjects were recruited into this study (Supp Table 1 and 2). Pregnant and non-pregnant women with acute or convalescent COVID-19 were recruited via the Mercy Hospital for Women, Royal Women's Hospital, Royal Melbourne Hospital, Austin Hospital, Alfred Hospital or The University of Melbourne. Healthy pregnant donors were recruited via the Mercy Hospital for Women and the University of Melbourne. Healthy non-pregnant donors were recruited via The University of Melbourne or buffy packs obtained from the Australian Red Cross LifeBlood (West Melbourne, Australia). Peripheral or cord blood was collected in heparinized tubes and peripheral blood monocular cells (PBMCs) were isolated via FicollPaque separation. Plasma was obtained from whole blood by centrifugation of heparin blood tubes at $300 \mathrm{~g}$ for $10 \mathrm{~min}$. Placenta samples were obtained and processed into single-cell suspension essentially as described with minor modifications(Koutsakos et al., 2018). Briefly, mononuclear cells were isolated and cryopreserved from placentae by mechanical dissociation and enzymatic digestion with $2 \mathrm{mg} / \mathrm{ml}$ of Collagenase D (Roche) in RPMI containing $0.2 \mathrm{mg} / \mathrm{mL}$ DNase I (Roche), $1 \mathrm{mM}$ HEPES, penicillin and streptomycin for 1 hour at $37^{\circ} \mathrm{C}$. Cells were filtered through a $70 \mu \mathrm{m}$ strainer and red blood cells were lysed using a solution of $0.168 \mathrm{M} \mathrm{NH}_{4} \mathrm{Cl}, 0.01 \mathrm{mM}$ EDTA and $12 \mathrm{mM} \mathrm{NaHCO}_{3}$ in $\mathrm{ddH}_{2} \mathrm{O}$. This study was a part of a larger study to understand immune responses to COVID-19 and immune perturbation during severe COVID-19.

Experiments conformed to the Declaration of Helsinki Principles and the Australian National Health and Medical Research Council Code of Practice. Written informed consents were obtained from all blood donors prior to the study. The study was approved by the Alfred Hospital (\#280/14), Melbourne Health (HREC/66341/MH-2020 and HREC/17/MH/53), Austin Health (HREC/63201/Austin-2020), Monash Health (HREC/15/MonH/64), Mercy Health (R14/25 and R04/29), Australian Red Cross Lifeblood (2015\#08), and the University of Melbourne (\#1442952, \#1749349, \#2056901, \#1443540, \#2056761, \#1955465, 2020 20782-12450-1, 2021-13973-14410-3 and 2021-13973-14410-3) Human Research Ethics Committees.

\section{Flow cytometry of whole blood, PBMCs and placenta.}

Fresh whole blood, PBMCs isolated from whole blood or placenta single-cell suspensions were used to assess cellular immunity, as previously described (Thevarajan et al., 2020). Four antibody panels were used to determine activation of (1) monocytes, T, B, NK and $ү \delta$ T cells, (2) $T_{F H}$ and ASC cell activation, (3) cytotoxicity profiles of $T$ cells and NK cells expressing intracellular granzymes $\mathrm{A}, \mathrm{B}, \mathrm{K}$ and $\mathrm{M}$ and perforin, and (4) activation and phenotypes of MAIT and $y \delta$ T cells (Supp Fig 6 and 7). Panels 1 and 2 were previously described (Koutsakos et al., 2021); panel 3 and 4 in Supp Table 4. Cells were stained, RBC lysed if from whole blood, then fixed in 1\% PFA, or stained intracellularly using the eBioscience $^{\mathrm{TM}}$ Foxp3/Transcription Factor Staining Buffer Set (Thermo Fisher Scientific, Carlsbad, CA, USA), as previously described (Thevarajan et al., 2020). Samples were acquired on a LSRII Fortessa (BD Biosciences) and analyzed using FlowJo v10 software.

\section{SARS-CoV-2 Receptor Binding Domain and Nucleocapsid ELISA.}

ELISA for the detection of RBD- or N-specific $\operatorname{lgG}$, IgM and IgA antibodies were performed as previously described (Amanat et al., 2020; Koutsakos et al., 2021; Rowntree et al., 2021), using flat bottom Nunc MaxiSorp 96-well plates (Thermo Fisher Scientific) for antigen coating $(2 \mu \mathrm{g} / \mathrm{ml}$ ), blocking with PBS (with w/v $1 \% \mathrm{BSA}$ ) and serial dilutions in PBS (with $\mathrm{v} / \mathrm{v}$ $0.05 \%$ Tween and $w / v 0.5 \% \mathrm{BSA}$ ). Endpoint titres were determined by interpolation from a sigmoidal curve fit (all R-squared values $>0.95$; GraphPad Prism 9) as the reciprocal dilution of plasma that produced $>15 \%$ (for $\lg A$ and $\lg G$ ) or $>30 \%$ (for $\lg M$ ) absorbance of the positive control at a 1:31.6 (IgG and $\operatorname{lgM}$ ) or 1:10 dilution (IgA). Seroconversion was defined as any titre greater than the mean plus two standard deviations of non-COVID-19 control plasma samples. 
medRxiv preprint doi: https://doi.org/10.1101/2021.08.21.21262399; this version posted August 23, 2021. The copyright holder for this preprint (which was not certified by peer review) is the author/funder, who has granted medRxiv a license to display the preprint in perpetuity.

It is made available under a CC-BY-NC-ND 4.0 International license .

\begin{abstract}
Antibody avidity ELISA.
The avidity of RBD-specific IgG and IgM were assessed by urea-mediated dissociation ELISA. Nunc Immuno MaxiSorp flat-bottom 96-well plates (Thermo Fisher Scientific) were coated with RBD protein overnight at $4^{\circ} \mathrm{C}$. Plates were washed and blocked with PBS (with $\mathrm{w} / \mathrm{v} 1 \% \mathrm{BSA}$ ) for at least $1 \mathrm{~h}$. Donor plasma was added in $\log _{0.5}$ dilutions and incubated for 2 $\mathrm{h}$ at room temperature. Wells were washed and $6 \mathrm{M}$ urea added and incubated for $15 \mathrm{~min}$. Bound antibodies were then detected using either HRP-conjugated anti-human IgG or antihuman $\operatorname{lgM}$ antibody as described previously. The amount (in percentage) of antibody remaining was determined by comparing the total area of the antibody titration curve (across 4 dilutions) in the presence and absence of urea treatment and is expressed as the avidity index.
\end{abstract}

\title{
Surrogate virus neutralization test.
}

Surrogate virus neutralization test ELISA (GenScript, NJ, USA) for the detection of antibodies that block the interaction between the SARS-CoV-2 spike protein RBD and the host receptor ACE2 was carried out as previously described (Rowntree et al., 2021). HRPconjugated recombinant SARS-CoV-2 RBD fragment bound to any circulating neutralizing antibodies to RBD preventing capture by the human ACE2 protein in the well, which was subsequently removed in the following wash step. Substrate reaction incubation time was 20 mins at room temperature and results were read by spectrophotometry. Colour intensity was inversely dependent on the titre of anti-SARS-CoV-2 neutralizing antibodies.

\section{Microneutralization test.}

Microneutralization activity of plasma samples was determined essentially as described (Juno et al., 2020a). Vero cells were used for the propagation of the SARS-CoV-2 isolate CoV/Australia/VIC01/2020 (Caly et al., 2020), stored at $-80^{\circ} \mathrm{C}$. Heat inactivated sera $\left(56^{\circ} \mathrm{C}\right.$ for $30 \mathrm{~min}$ ) was serially diluted and serum/virus mixtures assessed for residual virus infectivity in quadruplicate wells of Vero cells incubated in serum-free media containing $1 \mu \mathrm{g} / \mathrm{ml}$ of TPCK trypsin at $37^{\circ} \mathrm{C}$ and $5 \% \mathrm{CO}_{2}$. Viral cytopathic effect was read on day 5 . The neutralizing antibody titer was calculated using the Reed-Muench method, as described (Juno et al., 2020a).

\section{Total IgG glycosylation.}

Total IgG glycosylation was analysed as previously described using capillary electrophoresis (Mahan et al., 2015). Briefly, Melon gel IgG purification resin was used to purify total lgG from plasma according to the manufacturer's protocol (Thermo Fisher). N-linked glycans on purified IgG was analysed using LabChip GXII Touch Microchip-CE platform per manufacturer's protocol (Perkin Elmer).

\section{Coupling of carboxylated beads.}

A custom multiplex bead array was designed and coupled with SARS-CoV-1 and SARSCoV-2 spike 1 (stem, Sino Biological), spike 2 (head, ACRO Biosystems), RBD (BEI Resources) and nucleoprotein (ACRO Biosystems) as previously described (Selva et al., 2021) (Supp Table 3). In addition, SARS-CoV-2 spike trimers (kindly provided by Adam K. Wheatley) and SARS-CoV-2 spike trimers (BPS Bioscience) were also included. Tetanus toxoid (Sigma-Aldrich), influenza hemagglutinin (H1Cal2009; Sino Biological) and SIV gp120 (Sino Biological) were included as positive and negative control antigens, respectively. Antigens were covalently coupled to magnetic carboxylated beads (Bio Rad) using a twostep carbodiimide reaction and blocked with $0.1 \% \mathrm{BSA}$, before being resuspended and stored in PBS $0.05 \%$ sodium azide until use.

\section{Luminex bead-based multiplex assay.}


medRxiv preprint doi: https://doi.org/10.1101/2021.08.21.21262399; this version posted August 23, 2021. The copyright holder for this preprint (which was not certified by peer review) is the author/funder, who has granted medRxiv a license to display the preprint in perpetuity. It is made available under a CC-BY-NC-ND 4.0 International license.

A custom multiplex assay was used to investigate the isotypes and subclasses of SARSCoV-1 and -2 specific antibodies present in plasma samples (Selva et al., 2021). In brief, $20 \mu \mathrm{l}$ of working bead mixture (1000 beads per bead region) and $20 \mu \mathrm{l}$ of diluted plasma (final dilution 1:200) were added per well and incubated overnight at $4^{\circ} \mathrm{C}$ on a shaker. Fourteen different detectors were used to assess pathogen-specific antibodies. Single-step detection was done using phycoerythrin (PE)-conjugated mouse anti-human pan-lgG, IgG1-4 and IgA1-2 (Southern Biotech; $1.3 \mu \mathrm{g} / \mathrm{ml}, 25 \mu \mathrm{l} /$ well). C1q protein (MP Biomedicals) was first biotinylated (Thermo Fisher Scientific), then tetramerized with Streptavidin R-PE (SA-PE; Thermo Fisher Scientific) before dimers were used for single-step detection. For the detection of FcyR-binding, soluble recombinant FcyR dimers which come in higher affinity (FcyRlla-H131 and FcyRllla-V158) or lower affinity (FcyRlla-R131, FcyRllb and FcyRIIlaF158; $1.3 \mu \mathrm{g} / \mathrm{ml}$, 25 $\mu \mathrm{l} /$ well; kind gifts from Bruce D. Wines and P. Mark Hogarth) were first added to the beads, washed, and followed by the addition of SA-PE. For the detection of IgM, biotinylated mouse anti-human IgM (mab MT22; Mabtech; $1.3 \mu \mathrm{g} / \mathrm{ml}, 25 \mu \mathrm{l} /$ well) was first added to beads, washed, followed by SA-PE. Assays were performed in duplicates and read on the Flexmap 3D.

Data normalization for multiplex analysis.

Tetanus, H1Cal2009, BSA and SIV control antigens were removed from the analysis. Low signal features were removed when the $75^{\text {th }}$ percentile response for the feature was lower than the $75^{\text {th }}$ percentile of the BSA positive control. Right shifting was performed on each feature (detector-antigen pair) individually if it contained any negative values, by adding the minimum value for that feature back to all samples within that feature. Right-shifted data were log-transformed using the following equation, where $x$ is the right-shifted data and $y$ is the right-shifted log-transformed data: $y=\log 10(x+1)$ to achieve normal distribution. Data were furthered normalized by mean centering and variance scaling each feature using the $z-$ score function in Matlab in the subsequent multivariate analyses.

\section{Multivariable methods for identification of the key antibody features.}

A Least Absolute Shrinkage and Selection Operator (LASSO) penalised logistic regression model was used to determine the minimal set of features needed to predict pregnancy status during acute and convalescent COVID-19 (O'Brien, 2016). The LASSO shrinks data toward a simple, sparse model with fewer parameters and identifies the subset of antibody features that best discriminate between two groups. The frequency of selected features in resampling was considered as the criterion of variable importance (O'Brien, 2016). The feature selection stability was defined as the proportion of times that a feature was picked in the selected set of important features, when the model was repeatedly fitted to 1000 resampled subsets of data. Inner cross validations (CV) ranging from 4-fold to 10-fold were performed for each of the resampled datasets. Following model prediction, 10-fold CV was selected due to its consistency.

\section{Principal component analysis.}

PCA was performed in the Eigenvectors PLS toolbox (Eigenvector Research, Inc., Manson, USA) in MATLAB. PCA is an unsupervised technique that was used to visualise the variance in the samples based on all of the measured features and to reduce the dimensionality of the dataset (Jolliffe, 1986). Every Ab feature is assigned a loading, which in linear combinations creates a principal component (PC). Loadings and PCs are calculated to describe the maximum amount of variance in the dataset. Two-dimensional score plots were generated to visually assess separation between groups using their individual response measurements expressed through the PCs. The percent of variance described by each PC is a measure of the amount of variance in antibody response explained by that respective PC (Selva et al., 2021).

\section{Cytokine measurements}


Plasma levels of IL-1 $\beta$, IFN- $\alpha 2$, IFNy, TNFa, MCP-1 (CCL2), IL-6, IL-8 (CXCL8), IL-10, IL12p70, IL-17A, IL-18, IL-23 and IL-33 measured using the LEGENDplex TM Human Inflammation Panel 1 kit (BioLegend, San Diego, CA, USA). Donor plasma was diluted 1:2 and the assay was performed according to manufacturer's instructions. Samples were acquired on a FACSCanto ${ }^{\mathrm{TM}}$ II cytometer (BD Biosciences) and analysed with the online QOGNIT LEGENDplex ${ }^{\mathrm{TM}}$ program.

\section{Statistical analysis}

Data and statistical analysis were performed in GraphPad Prism (version 9). Non-linear regression plots were made in $R$ studio (version 4) using the ggplot package (Wickham, 2016) and LOESS model. PESTLE and SPICE software (version 6.1) were used for analysis of cytotoxic granzymes and perforin in NK cell and T cell subsets (Roederer et al., 2011).

\section{REFERENCES}

Allotey, J., Stallings, E., Bonet, M., Yap, M., Chatterjee, S., Kew, T., Debenham, L., Llavall, A.C., Dixit, A., Zhou, D., et al. (2020). Clinical manifestations, risk factors, and maternal and perinatal outcomes of coronavirus disease 2019 in pregnancy: living systematic review and meta-analysis. BMJ 370, m3320-m3320.

Amanat, F., Stadlbauer, D., Strohmeier, S., Nguyen, T.H.O., Chromikova, V., McMahon, M., Jiang, K., Arunkumar, G.A., Jurczyszak, D., Polanco, J., et al. (2020). A serological assay to detect SARS-CoV-2 seroconversion in humans. Nature Medicine 26, 1033-1036.

Areia, A.L., and Mota-Pinto, A. (2020). Can immunity during pregnancy influence SARSCoV-2 infection? - A systematic review. J Reprod Immunol 142, 103215.

Atyeo, C., Pullen, K.M., Bordt, E.A., Fischinger, S., Burke, J., Michell, A., Slein, M.D., Loos, C., Shook, L.L., Boatin, A.A., et al. (2021). Compromised SARS-CoV-2-specific placental antibody transfer. Cell 184, 628-642.e610.

Caligiuri, M.A. (2008). Human natural killer cells. Blood 112, 461-469.

Caly, L., Druce, J., Roberts, J., Bond, K., Tran, T., Kostecki, R., Yoga, Y., Naughton, W., Taiaroa, G., Seemann, T., et al. (2020). Isolation and rapid sharing of the 2019 novel coronavirus (SARS-CoV-2) from the first patient diagnosed with COVID-19 in Australia. Med J Aust 212, 459-462.

Chen, G., Liao, Q., Ai, J., Yang, B., Bai, H., Chen, J., Liu, F., Cao, Y., Liu, H., and Li, K. (2021). Immune Response to COVID-19 During Pregnancy. Front Immunol 12, 675476 675476.

Cooper, M.A., Fehniger, T.A., Turner, S.C., Chen, K.S., Ghaheri, B.A., Ghayur, T., Carson, W.E., and Caligiuri, M.A. (2001). Human natural killer cells: a unique innate immunoregulatory role for the CD56bright subset. Blood 97, 3146-3151.

Creanga, A.A., Johnson, T.F., Graitcer, S.B., Hartman, L.K., Al-Samarrai, T., Schwarz, A.G., Chu, S.Y., Sackoff, J.E., Jamieson, D.J., Fine, A.D., et al. (2010). Severity of 2009 Pandemic Influenza A (H1N1) Virus Infection in Pregnant Women. Obstet Gynecol 115, 717726.

Crovetto, F., Crispi, F., Llurba, E., Figueras, F., Gómez-Roig, M.D., and Gratacós, E. (2020). Seroprevalence and presentation of SARS-CoV-2 in pregnancy. The Lancet 396, 530-531.

Dong, E., Du, H., and Gardner, L. (2020). An interactive web-based dashboard to track COVID-19 in real time. Lancet Infect Dis 20, 533-534.

Edlow, A.G., Li, J.Z., Collier, A.-r.Y., Atyeo, C., James, K.E., Boatin, A.A., Gray, K.J., Bordt, E.A., Shook, L.L., Yonker, L.M., et al. (2020). Assessment of Maternal and Neonatal SARSCoV-2 Viral Load, Transplacental Antibody Transfer, and Placental Pathology in Pregnancies During the COVID-19 Pandemic. JAMA Network Open 3, e2030455-e2030455. Eickhoff, T.C., Sherman, I.L., and Serfling, R.E. (1961). Observations on Excess Mortality Associated with Epidemic Influenza. JAMA 176, 776-782.

Fenizia, C., Biasin, M., Cetin, I., Vergani, P., Mileto, D., Spinillo, A., Gismondo, M.R., Perotti, F., Callegari, C., Mancon, A., et al. (2020). Analysis of SARS-CoV-2 vertical transmission during pregnancy. Nature Communications 11, 5128. 
Flament, H., Rouland, M., Beaudoin, L., Toubal, A., Bertrand, L., Lebourgeois, S., Rousseau, C., Soulard, P., Gouda, Z., Cagninacci, L., et al. (2021). Outcome of SARS-CoV2 infection is linked to MAIT cell activation and cytotoxicity. Nature Immunology 22, 322-335. Flannery, D.D., Gouma, S., Dhudasia, M.B., Mukhopadhyay, S., Pfeifer, M.R., Woodford, E.C., Triebwasser, J.E., Gerber, J.S., Morris, J.S., Weirick, M.E., et al. (2021). Assessment of Maternal and Neonatal Cord Blood SARS-CoV-2 Antibodies and Placental Transfer Ratios. JAMA Pediatrics 175, 594-600.

Graham, C., Chooniedass, R., Stefura, W.P., Becker, A.B., Sears, M.R., Turvey, S.E., Mandhane, P.J., Subbarao, P., Investigators, C.S., and HayGlass, K.T. (2017). In vivo immune signatures of healthy human pregnancy: Inherently inflammatory or antiinflammatory? PLoS One 12, e0177813.

Grifoni, A., Weiskopf, D., Ramirez, S.I., Mateus, J., Dan, J.M., Moderbacher, C.R., Rawlings, S.A., Sutherland, A., Premkumar, L., Jadi, R.S., et al. (2020). Targets of T Cell Responses to SARS-CoV-2 Coronavirus in Humans with COVID-19 Disease and Unexposed Individuals. Cell 181, 1489-1501.e1415.

Habel, J.R., Nguyen, T.H.O., van de Sandt, C.E., Juno, J.A., Chaurasia, P., Wragg, K., Koutsakos, M., Hensen, L., Jia, X., Chua, B., et al. (2020). Suboptimal SARS-CoV2-specific $\mathrm{CD}^{+} \mathrm{T}$ cell response associated with the prominent HLA-A*02:01 phenotype. Proceedings of the National Academy of Sciences 117, 24384-24391.

Harris, J.W. (1919). INFLUENZA OCCURRING IN PREGNANT WOMEN: A STATISTICAL STUDY OF THIRTEEN HUNDRED AND FIFTY CASES. Journal of the American Medical Association 72, 978-980.

Harvey, R.A., Rassen, J.A., Kabelac, C.A., Turenne, W., Leonard, S., Klesh, R., Meyer, W.A., 3rd, Kaufman, H.W., Anderson, S., Cohen, O., et al. (2021). Association of SARSCoV-2 Seropositive Antibody Test With Risk of Future Infection. JAMA Intern Med 181, 672679.

Jang, W.-K., Lee, S.-Y., Park, S., Ryoo, N.H., Hwang, I., Park, J.M., and Bae, J.-G. (2021). Pregnancy Outcome, Antibodies, and Placental Pathology in SARS-CoV-2 Infection during Early Pregnancy. Int J Environ Res Public Health 18, 5709.

Jolliffe, M. (1986). Principal Component Analysis. ( Springer-Verlag, New York).

Joseph, N.T., Dude, C.M., Verkerke, H.P., Irby, L.S.S., Dunlop, A.L., Patel, R.M., Easley, K.A., Smith, A.K., Stowell, S.R., Jamieson, D.J., et al. (2021). Maternal Antibody Response, Neutralizing Potency, and Placental Antibody Transfer After Severe Acute Respiratory Syndrome Coronavirus 2 (SARS-CoV-2) Infection. Obstetrics \& Gynecology.

Jouan, Y., Guillon, A., Gonzalez, L., Perez, Y., Boisseau, C., Ehrmann, S., Ferreira, M., Daix, T., Jeannet, R., François, B., et al. (2020). Phenotypical and functional alteration of unconventional T cells in severe COVID-19 patients. Journal of Experimental Medicine 217. Juno, J., Tan, H.-X., Lee, W., Reynaldi, A., Kelly, H., Wragg, K., Esterbauer, R., Kent, H., Batten, C., Mordant, F., et al. (2020a). Humoral and circulating follicular helper T cell responses in recovered patients with COVID-19. Nat Med doi.org/10.1038/s41591-0200995-0.

Juno, J.A., and Kent, S.J. (2020). What Can Gamma Delta T Cells Contribute to an HIV Cure? Frontiers in Cellular and Infection Microbiology 10.

Juno, J.A., Tan, H.-X., Lee, W.S., Reynaldi, A., Kelly, H.G., Wragg, K., Esterbauer, R., Kent, H.E., Batten, C.J., Mordant, F.L., et al. (2020b). Immunogenic profile of SARS-CoV-2 spike in individuals recovered from COVID-19. medRxiv, 2020.2005.2017.20104869.

Juno, J.A., Tan, H.X., Lee, W.S., Reynaldi, A., Kelly, H.G., Wragg, K., Esterbauer, R., Kent, H.E., Batten, C.J., Mordant, F.L., et al. (2020c). Humoral and circulating follicular helper T cell responses in recovered patients with COVID-19. Nat Med 26, 1428-1434.

Kay, A.W., Fukuyama, J., Aziz, N., Dekker, C.L., Mackey, S., Swan, G.E., Davis, M.M., Holmes, S., and Blish, C.A. (2014). Enhanced natural killer-cell and T-cell responses to influenza $A$ virus during pregnancy. Proceedings of the National Academy of Sciences 111, 14506.

Ko, J.Y., DeSisto, C.L., Simeone, R.M., Ellington, S., Galang, R.R., Oduyebo, T., Gilboa, S.M., Lavery, A.M., Gundlapalli, A.V., and Shapiro-Mendoza, C.K. (2021). Adverse 
pregnancy outcomes, maternal complications, and severe illness among U.S. delivery hospitalizations with and without a COVID-19 diagnosis. Clin Infect Dis.

Kotlyar, A.M., Grechukhina, O., Chen, A., Popkhadze, S., Grimshaw, A., Tal, O., Taylor, H.S., and Tal, R. (2021). Vertical transmission of coronavirus disease 2019: a systematic review and meta-analysis. Am J Obstet Gynecol 224, 35-53.e33.

Koutsakos, M., Rowntree, L.C., Hensen, L., Chua, B.Y., van de Sandt, C.E., Habel, J.R., Zhang, W., Jia, X., Kedzierski, L., Ashhurst, T.M., et al. (2021). Integrated immune dynamics define correlates of COVID-19 severity and antibody responses. Cell Reports Medicine, 100208.

Koutsakos, M., Wheatley, A.K., Loh, L., Clemens, E.B., Sant, S., Nüssing, S., Fox, A., Chung, A.W., Laurie, K.L., Hurt, A.C., et al. (2018). Circulating TFH cells, serological memory, and tissue compartmentalization shape human influenza-specific B cell immunity. Science Translational Medicine 10, eaan8405.

Kuri-Cervantes, L., Pampena, M.B., Meng, W., Rosenfeld, A.M., Ittner, C.A.G., Weisman, A.R., Agyekum, R.S., Mathew, D., Baxter, A.E., Vella, L.A., et al. (2020). Comprehensive mapping of immune perturbations associated with severe COVID-19. Science Immunology 5, eabd7114.

Laing, A.G., Lorenc, A., del Molino del Barrio, I., Das, A., Fish, M., Monin, L., Muñoz-Ruiz, M., McKenzie, D.R., Hayday, T.S., Francos-Quijorna, I., et al. (2020). A dynamic COVID-19 immune signature includes associations with poor prognosis. Nature Medicine 26, 16231635.

Le Gars, M., Seiler, C., Kay, A.W., Bayless, N.L., Starosvetsky, E., Moore, L., Shen-Orr, S.S., Aziz, N., Khatri, P., Dekker, C.L., et al. (2019). Pregnancy-Induced Alterations in NK Cell Phenotype and Function. Front Immunol 10, 2469-2469.

Liu, H., Lin, X.-X., Huang, X.-B., Huang, D.-H., Song, S., Chen, Y.-J., Tang, J., Tao, D., Yin, Z.-N., Mor, G., and Liao, A.-H. (2021a). Systemic Characterization of Novel Immune Cell Phenotypes in Recurrent Pregnancy Loss. Front Immunol 12, 657552-657552.

Liu, Y., Gao, S., Zhao, Y., Wang, H., Pan, Q., and Shao, Q. (2021b). Decidual Natural Killer Cells: A Good Nanny at the Maternal-Fetal Interface During Early Pregnancy. Front Immunol 12.

Loh, L., Wang, Z., Sant, S., Koutsakos, M., Jegaskanda, S., Corbett, A.J., Liu, L., Fairlie, D.P., Crowe, J., Rossjohn, J., et al. (2016). Human mucosal-associated invariant T cells contribute to antiviral influenza immunity via IL-18-dependent activation. Proceedings of the National Academy of Sciences 113, 10133.

Long, Q.X., Liu, B.Z., Deng, H.J., Wu, G.C., Deng, K., Chen, Y.K., Liao, P., Qiu, J.F., Lin, Y., Cai, X.F., et al. (2020). Antibody responses to SARS-CoV-2 in patients with COVID-19. Nat Med 26, 845-848.

Louie, J.K., Acosta, M., Jamieson, D.J., and Honein, M.A. (2010). Severe 2009 H1N1 Influenza in Pregnant and Postpartum Women in California. New England Journal of Medicine 362, 27-35.

Lucas, C., Wong, P., Klein, J., Castro, T.B.R., Silva, J., Sundaram, M., Ellingson, M.K., Mao, T., Oh, J.E., Israelow, B., et al. (2020). Longitudinal analyses reveal immunological misfiring in severe COVID-19. Nature.

Mahan, A.E., Tedesco, J., Dionne, K., Baruah, K., Cheng, H.D., De Jager, P.L., Barouch, D.H., Suscovich, T., Ackerman, M., Crispin, M., and Alter, G. (2015). A method for highthroughput, sensitive analysis of IgG Fc and Fab glycosylation by capillary electrophoresis. J Immunol Methods 417, 34-44.

Malshe, N., Patnaik, S.K., Lalwani, S., Suryawanshi, P., Kulkarni, R., Mhaske, S., Mishra, A.C., and Arankalle, V. (2021). Perinatal transmission of SARS-CoV-2 and transfer of maternal $\mathrm{lgG} /$ neutralizing anti-SARS-CoV-2 antibodies from mothers with asymptomatic infection during pregnancy. Infection.

Mathew, D., Giles, J.R., Baxter, A.E., Greenplate, A.R., Wu, J.E., Alanio, C., Oldridge, D.A., Kuri-Cervantes, L., Pampena, M.B., D'Andrea, K., et al. (2020). Deep immune profiling of COVID-19 patients reveals patient heterogeneity and distinct immunotypes with implications for therapeutic interventions. bioRxiv. 
Mayassi, T., Barreiro, L.B., Rossjohn, J., and Jabri, B. (2021). A multilayered immune system through the lens of unconventional T cells. Nature 595, 501-510.

Nguyen, T.H., Rowntree, L.C., Pellicci, D.G., Bird, N.L., Handel, A., Kjer-Nielsen, L., Kedzierska, K., Kotsimbos, T.C., and Mifsud, N.A. (2014). Recognition of distinct crossreactive virus-specific CD8 $+\mathrm{T}$ cells reveals a unique TCR signature in a clinical setting. $\mathrm{J}$ Immunol 192, 5039-5049.

Nguyen, T.H.O., Rowntree, L.C., Petersen, J., Chua, B.Y., Hensen, L., Kedzierski, L., van de Sandt, C.E., Chaurasia, P., Tan, H.-X., Habel, J.R., et al. (2021). CD8+ T cells specific for an immunodominant SARS-CoV-2 nucleocapsid epitope display high naive precursor frequency and TCR promiscuity. Immunity 54, 1066-1082.e1065.

Nicholson, S., Karapanagiotidis, T., Khvorov, A., Douros, C., Mordant, F., Bond, K., Druce, J., Williamson, D.A., Purcell, D., Lewin, S.R., et al. (2021). Evaluation of 6 Commercial SARS-CoV-2 Serology Assays Detecting Different Antibodies for Clinical Testing and Serosurveillance. Open Forum Infectious Diseases 8.

Nörenberg, J., Jaksó, P., and Barakonyi, A. (2021). Gamma/Delta T Cells in the Course of Healthy Human Pregnancy: Cytotoxic Potential and the Tendency of CD8 Expression Make CD56+ yסT Cells a Unique Lymphocyte Subset. Front Immunol 11, 596489-596489.

O'Brien, C.M. (2016). Statistical Learning with Sparsity: The Lasso and Generalizations. International Statistical Review 84, 156-157.

Papageorghiou, A.T., Deruelle, P., Gunier, R.B., Rauch, S., García-May, P.K., Mhatre, M., Usman, M.A., Abd-Elsalam, S., Etuk, S., Simmons, L.E., et al. (2021). Preeclampsia and COVID-19: results from the INTERCOVID prospective longitudinal study. Am J Obstet Gynecol, S0002-9378(0021)00561-00565.

Pinheiro, M.B., Martins-Filho, O.A., Mota, A.P.L., Alpoim, P.N., Godoi, L.C., Silveira, A.C.O., Teixeira-Carvalho, A., Gomes, K.B., and Dusse, L.M. (2013). Severe preeclampsia goes along with a cytokine network disturbance towards a systemic inflammatory state. Cytokine $62,165-173$.

Rodda, L.B., Netland, J., Shehata, L., Pruner, K.B., Morawski, P.A., Thouvenel, C.D., Takehara, K.K., Eggenberger, J., Hemann, E.A., Waterman, H.R., et al. (2021). Functional SARS-CoV-2-Specific Immune Memory Persists after Mild COVID-19. Cell 184, 169183.e117.

Roederer, M., Nozzi, J.L., and Nason, M.C. (2011). SPICE: exploration and analysis of postcytometric complex multivariate datasets. Cytometry A 79, 167-174.

Rowntree, L.C., Chua, B.Y., Nicholson, S., Koutsakos, M., Hensen, L., Douros, C., Selva, K., Mordant, F.L., Wong, C.Y., Habel, J.R., et al. (2021). Robust correlations across six SARSCoV-2 serology assays detecting distinct antibody features. Clin Transl Immunology 10, e1258.

Sant, S., Jenkins, M.R., Dash, P., Watson, K.A., Wang, Z., Pizzolla, A., Koutsakos, M., Nguyen, T.H., Lappas, M., Crowe, J., et al. (2019). Human yס T-cell receptor repertoire is shaped by influenza viruses, age and tissue compartmentalisation. Clinical \& translational immunology 8, e1079-e1079.

Selva, K.J., van de Sandt, C.E., Lemke, M.M., Lee, C.Y., Shoffner, S.K., Chua, B.Y., Davis, S.K., Nguyen, T.H.O., Rowntree, L.C., Hensen, L., et al. (2021). Systems serology detects functionally distinct coronavirus antibody features in children and elderly. Nature Communications 12, 2037.

Siston, A.M., Rasmussen, S.A., Honein, M.A., Fry, A.M., Seib, K., Callaghan, W.M., Louie, J., Doyle, T.J., Crockett, M., Lynfield, R., et al. (2010). Pandemic 2009 Influenza A(H1N1) Virus Illness Among Pregnant Women in the United States. JAMA 303, 1517-1525.

Tan, C.W., Chia, W.N., Qin, X., Liu, P., Chen, M.I.C., Tiu, C., Hu, Z., Chen, V.C.-W., Young, B.E., Sia, W.R., et al. (2020). A SARS-CoV-2 surrogate virus neutralization test based on antibody-mediated blockage of ACE2-spike protein-protein interaction. Nature Biotechnology 38, 1073-1078.

Tasca, C., Rossi, R.S., Corti, S., Anelli, G.M., Savasi, V., Brunetti, F., Cardellicchio, M., Caselli, E., Tonello, C., Vergani, P., et al. (2021). Placental pathology in COVID-19 affected pregnant women: A prospective case-control study. Placenta 110, 9-15. 
medRxiv preprint doi: https://doi.org/10.1101/2021.08.21.21262399; this version posted August 23, 2021. The copyright holder for this preprint (which was not certified by peer review) is the author/funder, who has granted medRxiv a license to display the preprint in perpetuity.

It is made available under a CC-BY-NC-ND 4.0 International license .

Terzieva, A., Dimitrova, V., Djerov, L., Dimitrova, P., Zapryanova, S., Hristova, I., Vangelov, I., and Dimova, T. (2019). Early Pregnancy Human Decidua is Enriched with Activated, Fully Differentiated and Pro-Inflammatory Gamma/Delta T Cells with Diverse TCR Repertoires. Int J Mol Sci 20.

Thevarajan, I., Nguyen, T.H.O., Koutsakos, M., Druce, J., Caly, L., van de Sandt, C.E., Jia, X., Nicholson, S., Catton, M., Cowie, B., et al. (2020). Breadth of concomitant immune responses prior to patient recovery: a case report of non-severe COVID-19. Nat Med 26, 453-455.

Wang, X., Yang, P., Zheng, J., Liu, P., Wei, C., Guo, J., Zhang, Y., and Zhao, D. (2021). Dynamic changes of acquired maternal SARS-CoV-2 IgG in infants. Sci Rep 11, 8021-8021. Weiskopf, D., Schmitz, K.S., Raadsen, M.P., Grifoni, A., Okba, N.M.A., Endeman, H., van den Akker, J.P.C., Molenkamp, R., Koopmans, M.P.G., van Gorp, E.C.M., et al. (2020). Phenotype and kinetics of SARS-CoV-2-specific T cells in COVID-19 patients with acute respiratory distress syndrome. Sci Immunol 5, eabd2071.

Wheatley, A.K., Juno, J.A., Wang, J.J., Selva, K.J., Reynaldi, A., Tan, H.-X., Lee, W.S., Wragg, K.M., Kelly, H.G., Esterbauer, R., et al. (2021). Evolution of immune responses to SARS-CoV-2 in mild-moderate COVID-19. Nature Communications 12, 1162.

Wickham, H. (2016). ggplot2-Elegant Graphics for Data Analysis. (New York: SpringerVerlag).

Wragg, K.M., Tan, H.-X., Kristensen, A.B., Nguyen-Robertson, C.V., Kelleher, A.D., Parsons, M.S., Wheatley, A.K., Berzins, S.P., Pellicci, D.G., Kent, S.J., and Juno, J.A. (2020). High CD26 and Low CD94 Expression Identifies an IL-23 Responsive Vd2+ T Cell Subset with a MAIT Cell-like Transcriptional Profile. Cell Reports 31.

Zambrano, L.D., Ellington, S., Strid, P., Galang, R.R., Oduyebo, T., Tong, V.T., Woodworth, K.R., Nahabedian, J.F., Azziz-Baumgartner, E., Gilboa, S.M., et al. (2020). Update: Characteristics of Symptomatic Women of Reproductive Age with Laboratory-Confirmed SARS-CoV-2 Infection by Pregnancy Status - United States, January 22-October 3, 2020. MMWR Morb Mortal Wkly Rep 69, 1641-1647.

Zhang, X., Tan, Y., Ling, Y., Lu, G., Liu, F., Yi, Z., Jia, X., Wu, M., Shi, B., Xu, S., et al. (2020). Viral and host factors related to the clinical outcome of COVID-19. Nature.

Zhao, S., Xie, T., Shen, L., Liu, H., Wang, L., Ma, X., Wu, J., Yuan, S., Mor, G., and Liao, A. (2021). An Immunological Perspective: What Happened to Pregnant Women After Recovering From COVID-19? Front Immunol 12, 631044-631044. 
medRxiv preprint doi: https://doi.org/10.1101/2021.08.21.21262399; this version posted August 23, 2021. The copyright holder for this preprint (which was not certified by peer review) is the author/funder, who has granted medRxiv a license to display the preprint in perpetuity.

It is made available under a CC-BY-NC-ND 4.0 International license .

\section{FIGURE LEGENDS}

Figure 1. COVID-19 pregnancy cohort. (A) Schematic depicting recruitment of pregnant and non-pregnant women with acute or convalescent COVID-19 or who were not exposed to SARS-CoV-2. (B) Location during acute COVID-19 for pregnant (P) and non-pregnant (Non$P)$ donors. (C-D) Timeline showing days post disease symptom onset at which blood samples were collected for (C) pregnant and (D) non-pregnant women who had COVID-19. (E) Median days post symptom onset in acute $(P n=13$, Non- $P n=12)$ and convalescent $(P$ $n=15$, Non- $P n=33$ ) pregnant and non-pregnant donors. Donors with longitudinal sampling are represented for each timepoint collected. (F) Median age of pregnant and non-pregnant healthy ( $n=21$ and 37$)$, acute $(n=8$ and 9$)$ or convalescent $(n=13$ and 18) COVID-19 donors. Median and range are shown. $(G)$ Gestational age in weeks for healthy $(n=21)$ and COVID$19(\mathrm{n}=25)$ pregnant donors. Means and standard deviations are shown. $(\mathrm{H})$ Schematics showing a sub-group of recovered COVID-19 $(n=9)$ or healthy $(n=6)$ pregnant donors from whom matched cord blood and placenta tissue were collected in addition to maternal blood. (I) Median age in years for healthy $(n=6)$ and COVID-19 pregnant donors $(n=9)$. Median and range are shown. $(\mathrm{J})$ Timeline showing the week of gestation at which each pregnant donor became symptomatic with COVID-19 $(n=9)$.

Figure 2. Analysis of SARS-CoV-2-specific antibodies in pregnant women and cord blood. (A) RBD-specific $\lg G$, $\lg M$ and $\lg A$ dilution curves for healthy $(P n=10$, Non- $P$ $n=27 X)$, acute COVID-19 ( $P n=13$, Non- $n=11$ ) or convalescent COVID-19 ( $\mathrm{n}=15$, Non- $P$ $n=33 X$ ) pregnant and non-pregnant donors. (B) $\log _{10} R B D$-specific antibody titres in pregnant and non-pregnant donors. Orange dashed lines indicate seroconversion cut-off based on healthy pregnant and non-pregnant titres (mean plus two standard deviations). (C) Avidity of RBD-specific $\lg G$ and $\lg M$ antibodies in pregnant $(n=7)$ and non-pregnant $(n=12)$ COVID-19 donors performed across sequential bleeds. (D) Proportions of pregnant and nonpregnant donors who seroconverted according to RBD-specific $\lg G$, IgM and $\lg A$. (E) RBDIgG kinetics for pregnant (red) and non-pregnant (blue) COVID-19 donors. LOESS regression line and $95 \% \mathrm{Cl}$ are shown. Statistics shown are Spearman correlation coefficients, ${ }^{* *} p<0.01$. (F) Percent inhibition as determined by surrogate virus neutralization test in acute ( $P n=13$, Non- $P n=11)$, and convalescent $(P n=15$, Non- $P n=28$ ) pregnant or non-pregnant women. Orange dashed line indicates seroconversion with neutralizing antibodies. (G) $\log _{10}$ RBD- and N-specific antibody titres in cord blood from healthy $(n=5-10)$ and COVID-19 $(n=9)$ pregnancies. Orange dashed lines indicate seroconversion cut-off based on healthy cord blood titres (mean plus two standard deviations). (H) RBD-specific $\lg \mathrm{G}, \lg \mathrm{M}$ and $\lg \mathrm{A}$, and $\mathrm{N}$-specific $\lg \mathrm{G}$ as well as sVNT percentage inhibition in matched maternal-cord dyads $(n=9)$. Wilcoxon test was used to determine statistical significance, ${ }^{* *} p<0.01$. (I) Proportions of pregnant, non-pregnant and cord blood donors who seroconverted with different combinations of RBD-specific or neutralizing antibodies. Seroconversion was counted if a donor was positive at any timepoint if multiple samples were collected. (J) Correlations between RBD-lgG titres and (i) percent inhibition determined by sVNT or (ii) N-lgG titres in COVID-19 cord blood $(n=9)$. Statistical significance was determined using Spearman's rank correlation.

Figure 3. Multiplex analysis of antibody subclasses and isotypes, and FcyRs. (Ai) Principal component plots showing pregnant (red, $n=13$ ) and non-pregnant (blue, $n=11$ ) donors with acute COVID-19. (Aii) Loading plot showing the 14 selected features that cause pregnant and non-pregnant donors to separate along the PC1 axis. Principal component plot of selected features. (Bi) Principal component plots showing pregnant (red, $n=8$ ) and nonpregnant (blue, $n=10$ ) donors with convalescent COVID-19. (Bii) Loading plot showing the 10 selected features that cause pregnant and non-pregnant donors to separate along the PC1 axis. Principal component plot of selected features. (Ci) Principal component plots showing convalescent pregnant ( $\mathrm{red}, \mathrm{n}=8$ ) and cord blood (orange, $\mathrm{n}=3$ ) from COVID-19 pregnancies. (Cii) Loading plot showing the five selected features that cause pregnant and 
medRxiv preprint doi: https://doi.org/10.1101/2021.08.21.21262399; this version posted August 23, 2021. The copyright holder for this preprint (which was not certified by peer review) is the author/funder, who has granted medRxiv a license to display the preprint in perpetuity. It is made available under a CC-BY-NC-ND 4.0 International license .

non-pregnant donors to separate along the PC1 axis. Principal component plot of selected features. $\lg \mathrm{M}$ and $\lg \mathrm{A}$ features were excluded from this comparison due to the lack of these isotypes in the cord blood which would masked any antigen-specific findings. SARS2, SARS-CoV-2; SARS1, SARS-CoV-1; S, spike, S1, spike subunit 1 (stalk); S2, spike subunit 2 (head); N, nucleocapsid; RBD, receptor binding domain.

Figure 4. Activation in antibody-secreting $B$ cells and $C D 4^{+} \mathrm{T}$ follicular helper cells. $(A)$ $\mathrm{CD}^{2} 7^{+} \mathrm{CD} 38^{+}$antibody-secreting cells (ASCs) were gated from the CD19+CD3- $\mathrm{B}$ cell population. (B) Frequencies of ASCs of $B$ cells in healthy $(P n=18$, Non- $P n=8)$, acute $(P$ $n=13$, Non- $P n=8)$ or convalescent $(P n=15$, Non- $P n=10)$ pregnant or non-pregnant women. Means and standard deviations are shown. (C) Fold-difference in the mean frequency of ASCs between healthy and acute COVID-19 for pregnant and non-pregnant donors. (D) Kinetics of ASCs against the day post symptom onset for pregnant and non-pregnant COVID-19 donors. LOESS regression line and 95\% Cl are shown. (E) Correlations between RBD-specific antibody titres and the frequency of ASCs for pregnant and non-pregnant COVID-19 donors. No statistical significance was reached when using the Spearman correlation method. $(\mathrm{F}) \mathrm{T}_{\mathrm{FH}}$ cells were defined as $\mathrm{CXCR} 5^{+} \mathrm{CD} 4^{+} \mathrm{T}$ cells and their activation was determined by expression of PD-1 and ICOS. (G-I) Frequencies of PD- $1^{+} I \mathrm{COS}^{+}$total $\mathrm{T}_{\mathrm{FH}}$ cells $(G), C X C R 3^{+} T_{F H} 1$ cells $(H)$ and $C X C R 3^{-} T_{F H} 2 / 17$ cells $(I)$ healthy $(P n=18$, Non- $P$ $n=14)$, acute $(P n=13$, Non- $P n=8)$ or convalescent $(P n=15$, Non- $P n=11)$ pregnant or nonpregnant women. (J-K) Correlations between RBD-specific antibodies and PD- $1^{+} \mathrm{ICOS}^{+} \mathrm{T}_{\mathrm{FH}} 1$ (J) or $\mathrm{T}_{\mathrm{FH}} 2 / 17(\mathrm{~K})$ cells. No statistical significance was reached when using the Spearman correlation method. (L) Differential gating of $\mathrm{CD}^{+} 4^{+} \mathrm{CD} 16^{-}$classical, $\mathrm{CD} 14^{+} \mathrm{CD} 16^{+}$ inflammatory and $\mathrm{CD}^{-} \mathrm{CD}^{-} 6^{+}$patrolling monocytes. (M) Proportions of classical, inflammatory and patrolling monocytes. Means and standard deviations are shown. No statistical significance was achieved when comparing individual monocyte populations in pregnant and non-pregnant donors by Mann-Whitney $U$ test.

Figure 5. Differential NK cell and $y \delta ~ T$ cell activation in pregnant women with COVID19. (A) NK cells were defined as $\mathrm{CD} 3^{-} \mathrm{CD} 56^{+}$and their activation was determined by HLADR expression. (B) Frequencies of HLA-DR ${ }^{+}$NK cells in healthy $(P n=18$, Non- $P n=8)$, acute $(P n=13$, Non- $P n=9)$ and convalescent $(P n=15$, Non- $P n=10)$ COVID-19 pregnant and nonpregnant women. ${ }^{*} p<0.05,{ }^{* * * *} p<0.0001$. (C) Fold-difference in the mean frequency of HLA$\mathrm{DR}^{+} \mathrm{NK}$ cells from healthy to acute COVID-19 for pregnant and non-pregnant donors. (D) Correlation between the frequency of $\mathrm{HLA}^{-\mathrm{DR}^{+}} \mathrm{NK}$ cells and days post symptom onset for pregnant and non-pregnant women with COVID-19. LOESS regression line and $95 \% \mathrm{Cl}$ are shown. Statistics shown are Spearman correlation coefficient, ${ }^{*} p<0.05$. (E) Proportions of $\mathrm{CD}^{\text {bright }}{ }^{\text {bD 16 }}{ }^{-}, \mathrm{CD}^{\mathrm{dim}} \mathrm{CD} 16^{+}$, and intermediate non-CD56 ${ }^{\text {bright/dim }}$ NK cells. ${ }^{*} \mathrm{p}<0.05$, ${ }^{* * *} p<0.001$. (F) Proportions of granzymes $A, B, K$ and $M$ and perforin expression in total, (i) CD56 ${ }^{\text {dim }}$ CD $16^{+}$or (ii) CD56 ${ }^{\text {bright }}$ CD $16^{-}$NK cells. Inner pie chart describes the proportions of NK cells expressing multiple cytotoxic molecules and the outer circles depict which molecules contribute to the multifunctionality. Permutations test was used to determine statistical significance. (G) $ү \bar{\delta} \mathrm{T}$ cells were defined as $C D 3^{+} \gamma \delta \mathrm{TCR}^{+}$lymphocytes and their activation determined by HLA-DR and CD38 co-expression. $(\mathrm{H})$ Frequencies of $\mathrm{HLA}$ $D^{+} C D 38^{+} \gamma \delta T$ cells in pregnant and non-pregnant women who were healthy $(P n=18$, Non$P n=8)$ or had acute ( $P n=13$, Non- $P n=8)$ or convalescent $(P n=15$, Non- $P n=10)$ COVID-19. ${ }^{*} p<0.05,{ }^{* *} p<0.01$. (I) Fold-difference in the mean frequency of HLA-DR ${ }^{+} \mathrm{CD} 38^{+} \mathrm{\gamma} \delta \mathrm{T}$ cells from healthy to acute COVID-19 for pregnant and non-pregnant donors. (J) Correlation between the frequency of $\mathrm{HLA}-\mathrm{DR}{ }^{+} \mathrm{CD} 38^{+} \mathrm{y} \overline{\mathrm{T}}$ cells and days post symptom onset for pregnant and non-pregnant women with COVID-19. LOESS regression line and $95 \% \mathrm{Cl}$ are shown. Statistics shown are Spearman correlation coefficient, ${ }^{\star *} p<0.01$. (K) Vס1, Vס2 and non- Vס1/2 subsetting of $y \delta$ T cells. (L) Proportions of V $\delta 1, V \delta 2$ and non-V $\delta 1 / 2$ within the $\mathrm{HLA}-\mathrm{DR}{ }^{+} \mathrm{CD} 38^{+}{ }^{\mathrm{y}} \delta \mathrm{T}$ cell population. (M) Correlation between the frequency of (i) V $\delta 1$ or (ii) Vठ2 $T$ cells and days post symptom onset for pregnant and non-pregnant women with COVID-19. (N) MAIT cells defined by binding of MR1-5-OP-RU tetramer and expression of 
medRxiv preprint doi: https://doi.org/10.1101/2021.08.21.21262399; this version posted August 23, 2021. The copyright holder for this preprint (which was not certified by peer review) is the author/funder, who has granted medRxiv a license to display the preprint in perpetuity.

It is made available under a CC-BY-NC-ND 4.0 International license.

Va7.2. (O) MAIT cell frequencies of $\mathrm{CD}^{+}$lymphocytes. (P) HLA-DR and CD38 expression

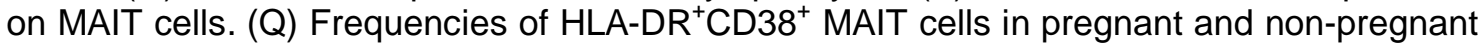
women who were healthy $(P n=11$, Non- $P n=6)$ or had acute $(P n=4$, Non- $P n=5)$ or convalescent $(P \mathrm{n}=6$, Non- $\mathrm{P} n=6)$ COVID-19. ${ }^{* *} p<0.01$. Means and standard deviations are shown. Mann Whitney $U$ test was used to determine statistical significance unless otherwise stated.

Figure 6. Cytokine and chemokine concentrations and proportions within blood plasma. ( $A$, left) Concentrations of 13 cytokines and chemokines measured in pregnant and non-pregnant women who were healthy $(P n=15$, Non- $P n=11)$ or had acute $(P n=13$, Non- $P$ $n=11)$ or convalescent $(P n=14$, Non- $P n=26)$ COVID-19. Mann Whitney $U$ test was used to determine statistical significance, ${ }^{*} p<0.05,{ }^{* *} p<0.01,{ }^{* * *} p<0.001,{ }^{* * *} p<0.0001$. (A, right) Correlation between cytokine or chemokine concentration and days post symptom onset for pregnant and non-pregnant COVID-19 donors. LOESS regression line and $95 \% \mathrm{Cl}$ are shown. Statistics shown are Spearman correlation coefficient, ${ }^{*} p<0.05$. (B) Quantification of the total cytokine and chemokine concentration. Means and standard deviations are shown. (C) Mean proportion of each cytokine and chemokine in pregnant and non-pregnant women who were healthy or had acute or convalescent COVID-19.

Figure 7. Summary data of key differences in immune parameters between pregnant and non-pregnant women. (A) Heatmap depicting the mean of 65 selected immune parameters for healthy, acute and convalescent pregnant and non-pregnant women. Data shown are calculated from z-scored values. (a-c) Volcano plots of 65 selected cellular and humoral immune parameters between pregnant and non-pregnant women who were (B) healthy or had (C) acute or (D) convalescent COVID-19. 
medRxiv preprint doi: https:Hoi.org/10.1101/2021.08.2121262399; this version posted August 23, P001, The cepyrightholder for this preprint (which was not certified by peer review) is the author/funder, who has granted medRxiv a license to d splay the preprint in perpetuity.

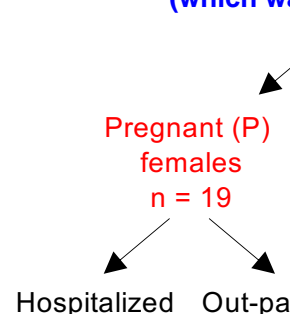
COVID-19

$\mathrm{n}=10$

Hospitalized Out-patient

$\begin{array}{lc}n=8 & \text { Out-patient } \\ n=16\end{array}$

COVID-19 pregnancy cohort (sampling day)

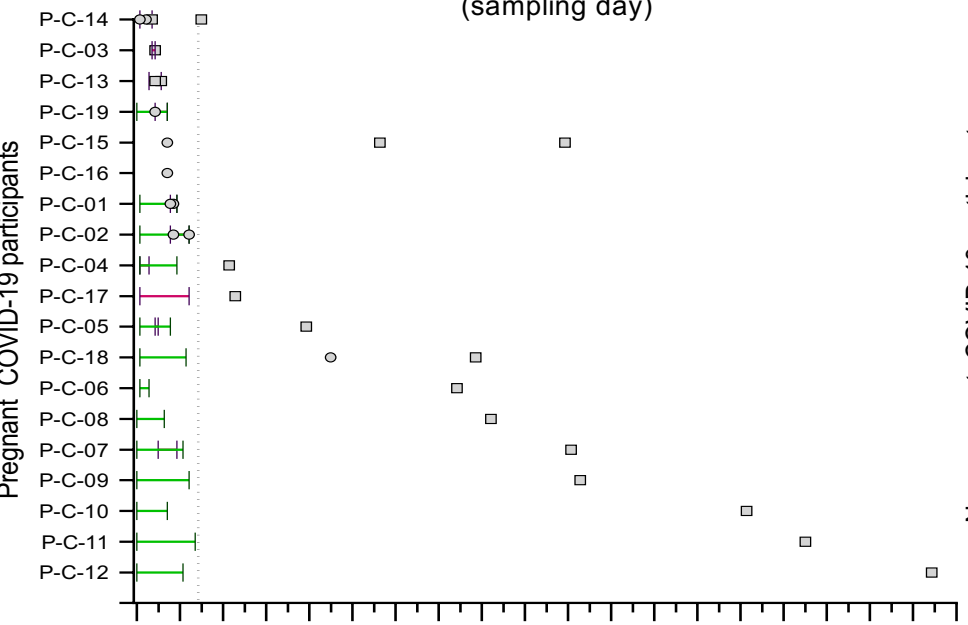

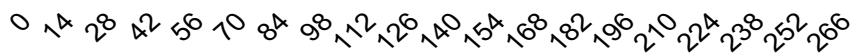
Day post symptom onset
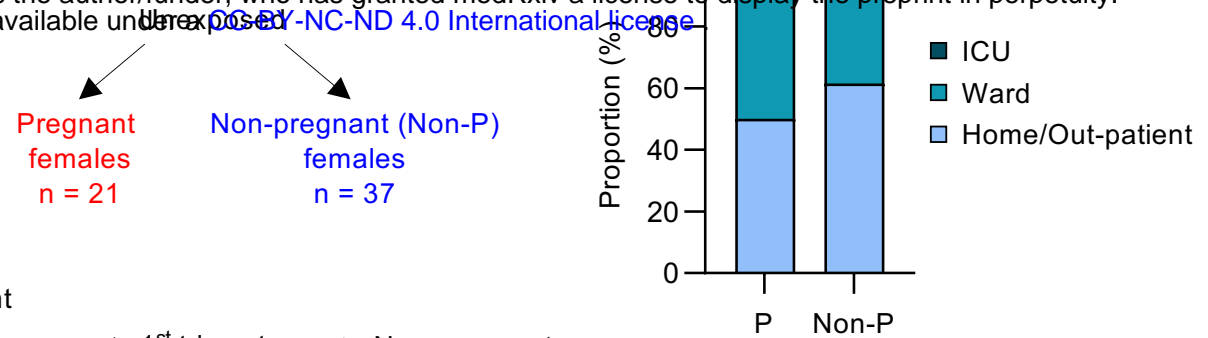

$\diamond 1^{\text {st }}$ trimester $\triangle$ Non-pregnant
$\checkmark 2^{\text {nd }}$ trimester $\mapsto$ Symptom duration
$\square 3^{\text {rd }}$ trimester $\longmapsto$ Hospital duration D

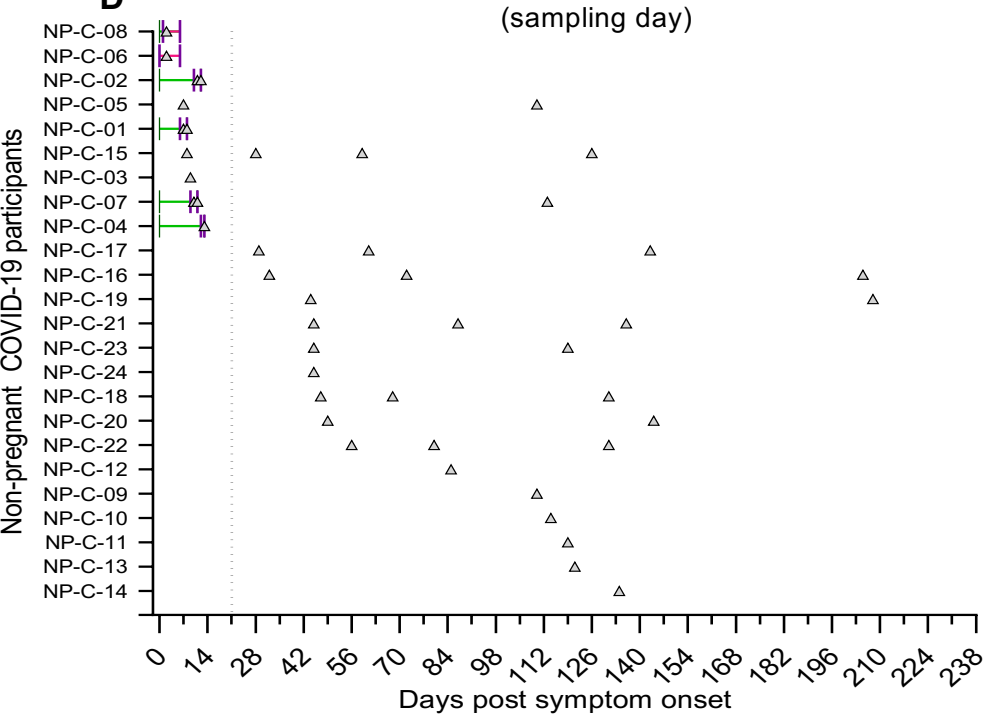

- Pregnant

E

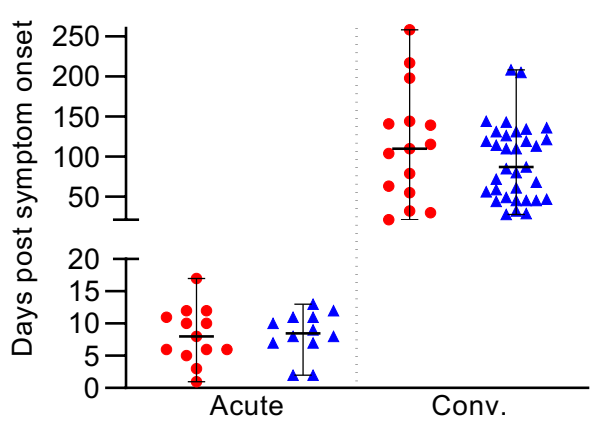

F

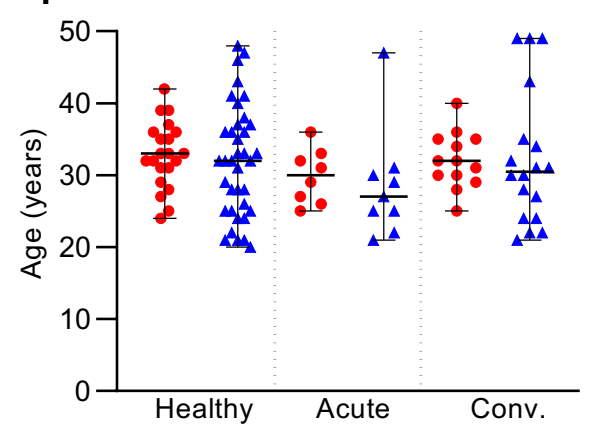

G

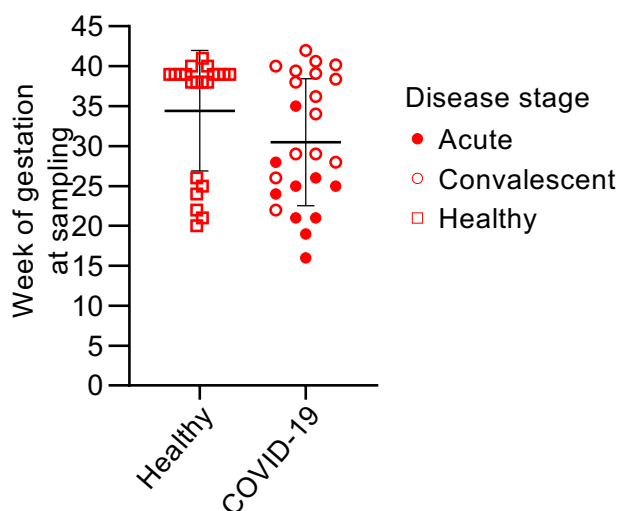

H

Matched maternal blood, cord blood (CB), placenta

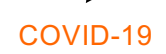

pregnancies

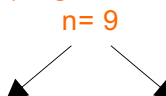

Hospitalized Out-patient $n=3 \quad n=6$

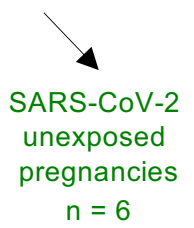

$=6$

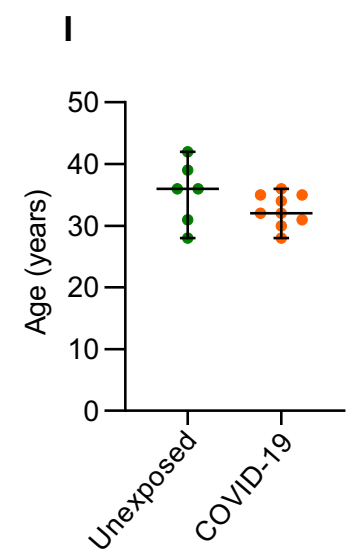

Figure 1 Habel et al.

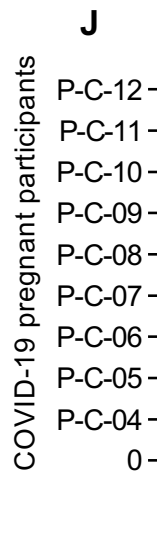

J

Gestation at COVID-19 diagnosis (matched maternal-cord-placenta pregnancies)
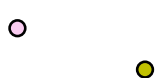

$\diamond$ Hospitalized

Out-patient 
I

$\lg M$

$\lg A$

1007

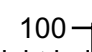

007 .

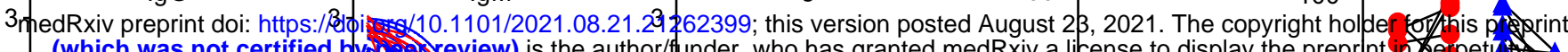
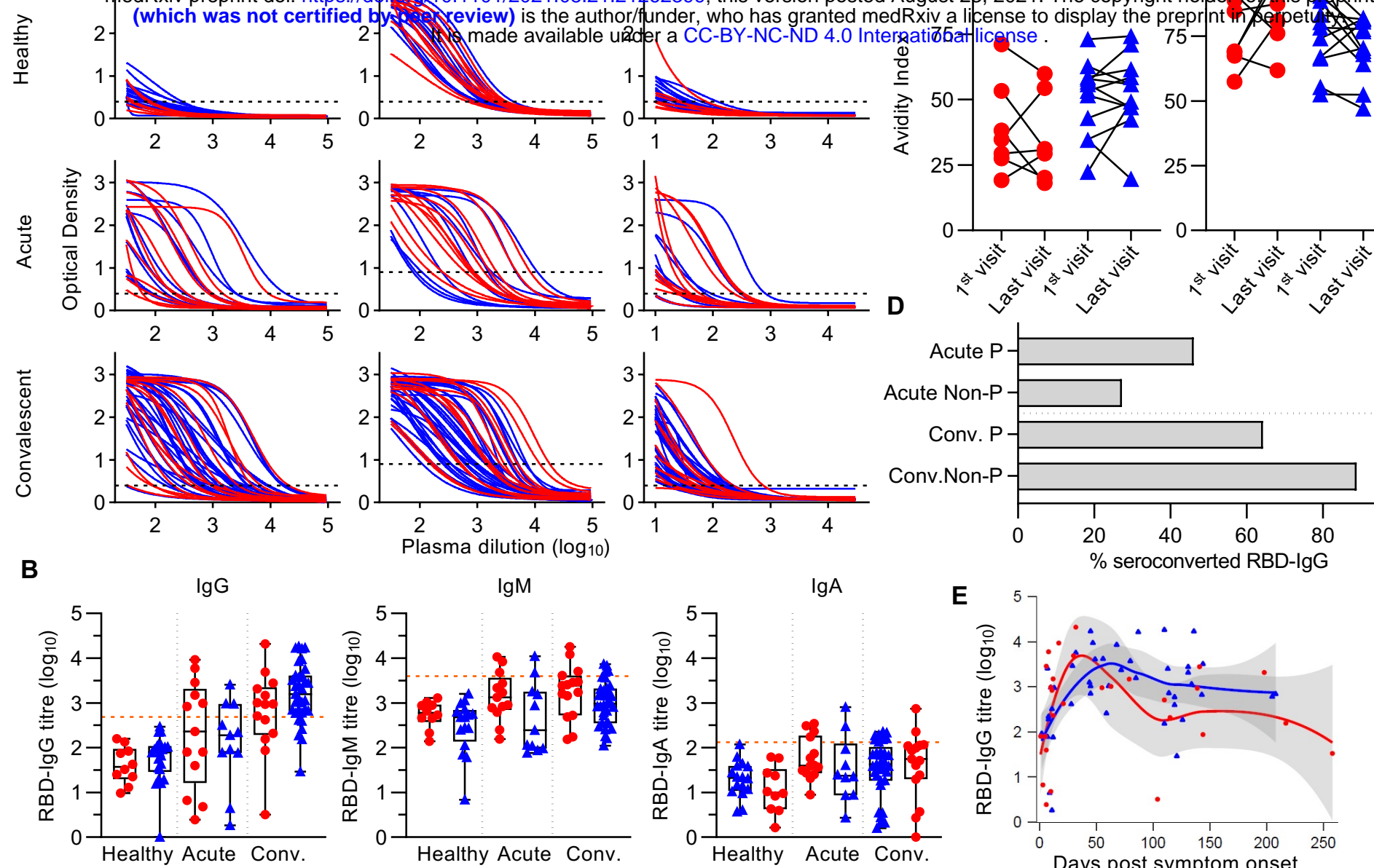

B

$\lg G$

$\lg M$
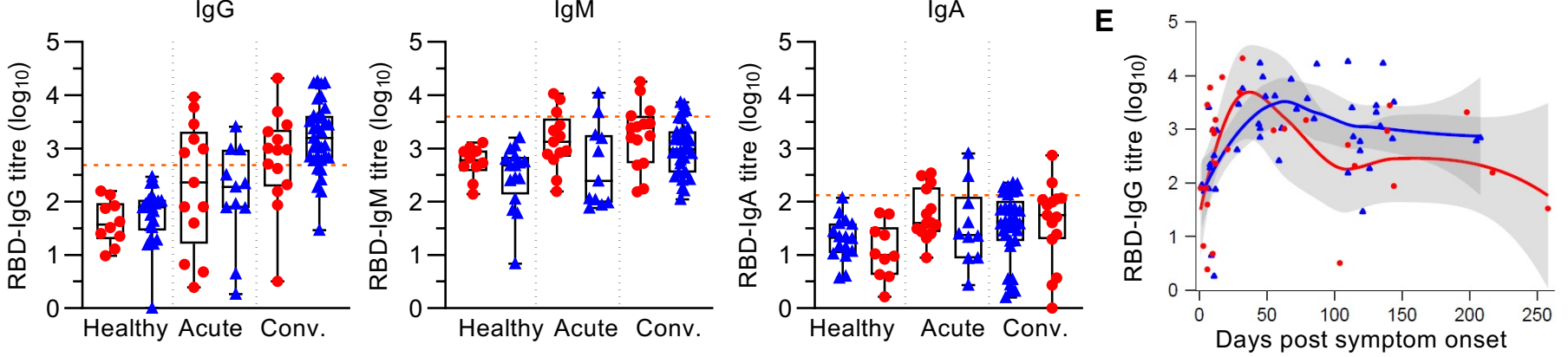

$F$

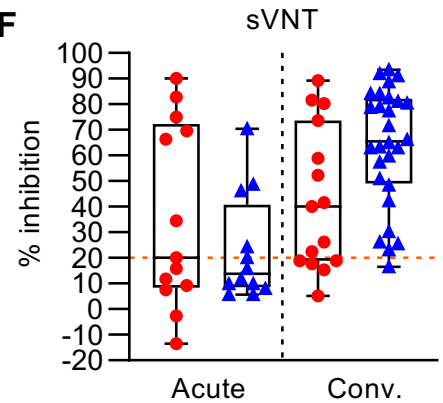

H

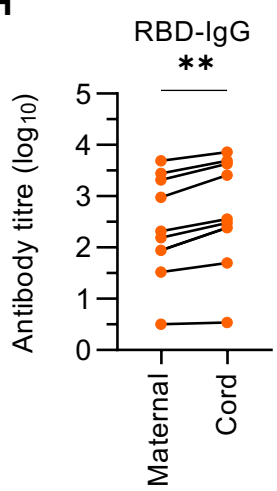

Maternal-cord COVID-19 pairs

- Non-pregnant (Non-P)

- Unexposed pregnancy

- COVID-19 pregnancy

I

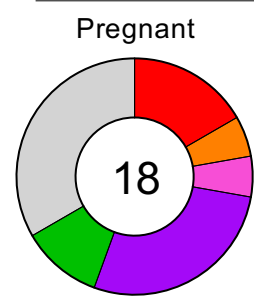

Non-pregnant

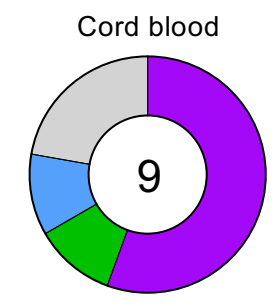

$\mathrm{sVNT}^{+} \operatorname{lgG}{ }^{+} \operatorname{lgM}^{+} \lg \mathrm{A}^{+} \square \mathrm{sVNT}^{+} \operatorname{lgG}{ }^{+} \lg \mathrm{M}^{+}$

$\square$ sVNT

$\square \lg G^{+}$
G

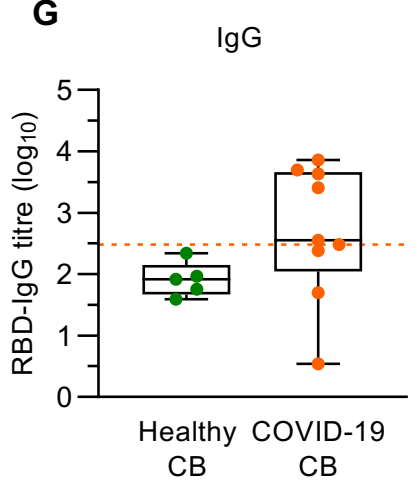

$\lg \mathrm{M}$

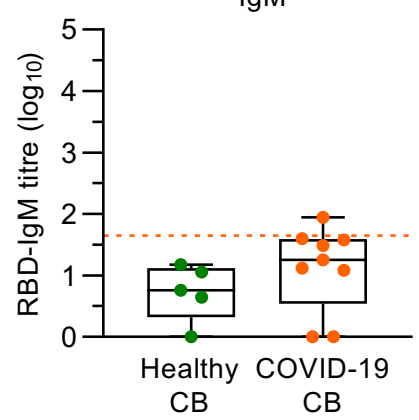

J

(i)

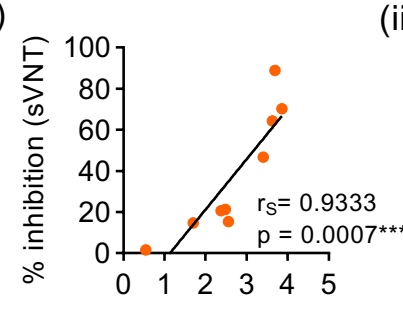

RBD-lgG titre $\left(\log _{10}\right)$

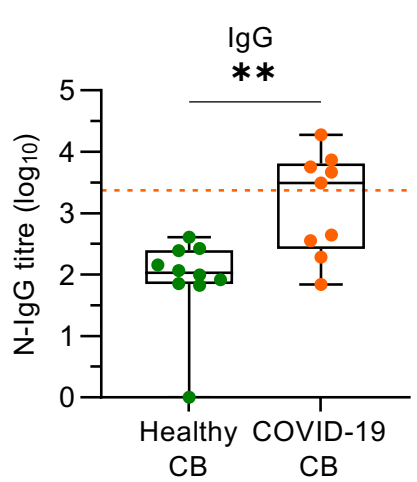

$\lg A$

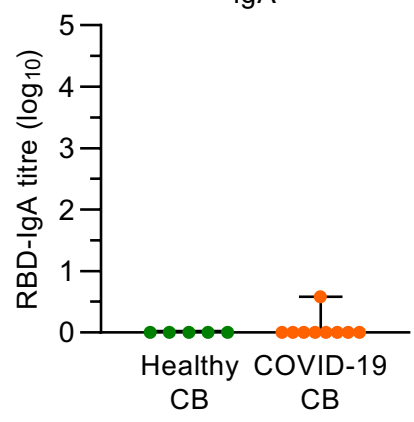

(ii)

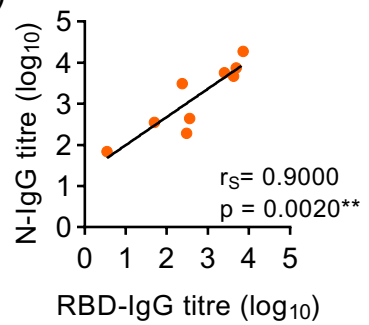




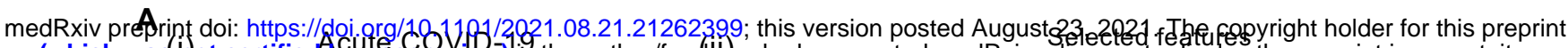
(which was (b)ot certified Afy peer review) is the author/fundïr), who has granted medRxiva license to display the preprint in perpetuity.

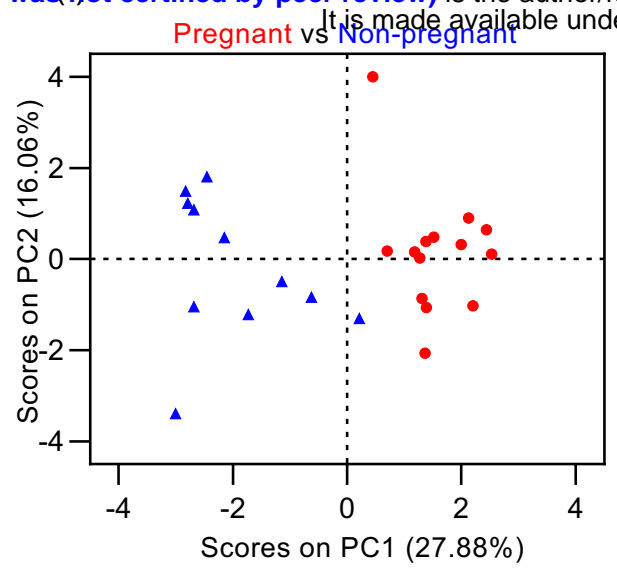

B

(i) Convalescent COVID-19

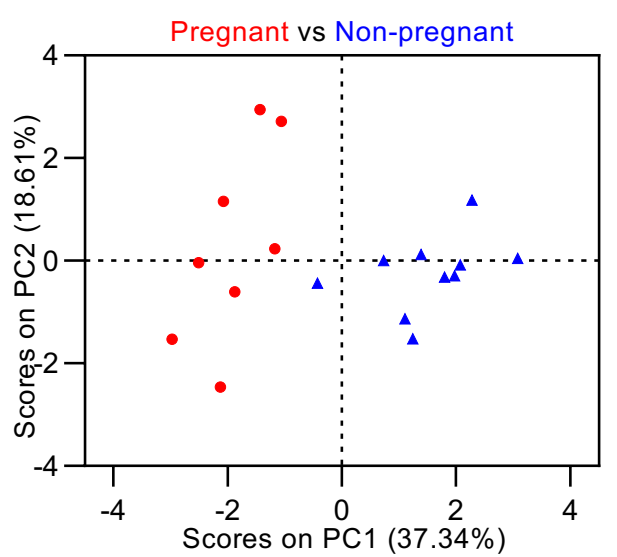

(ii)
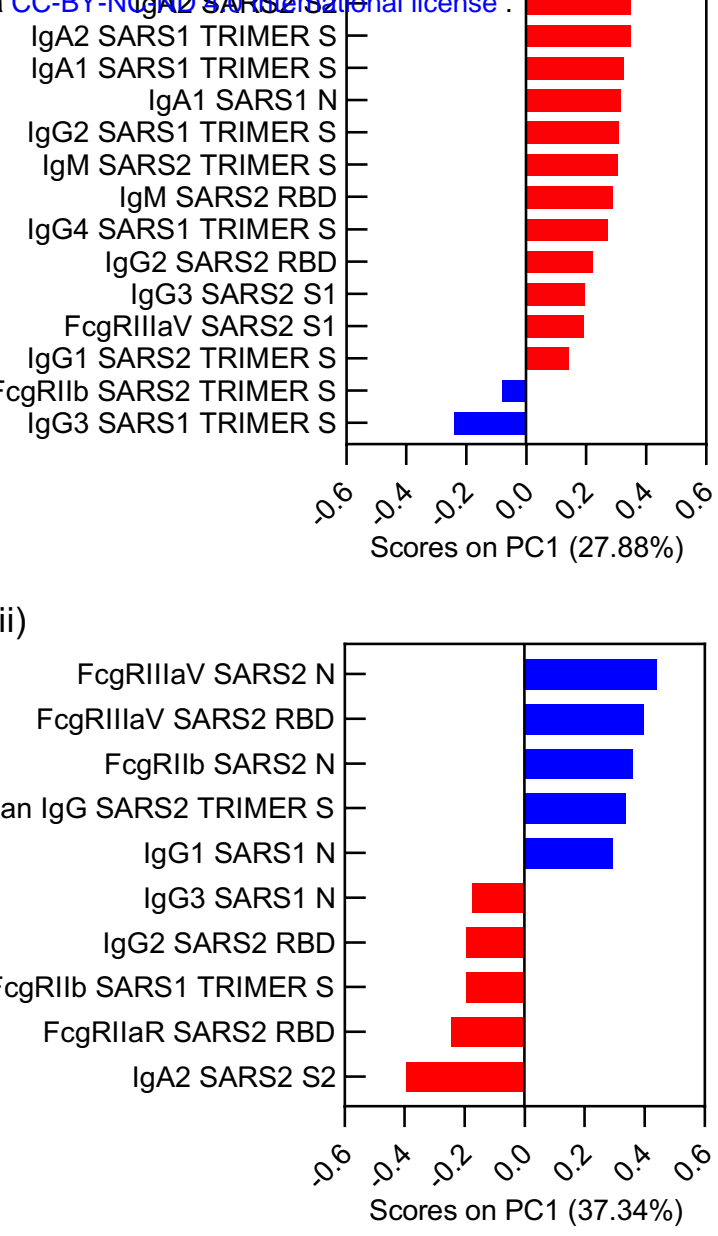

C

(i) Convalescent COVID-19

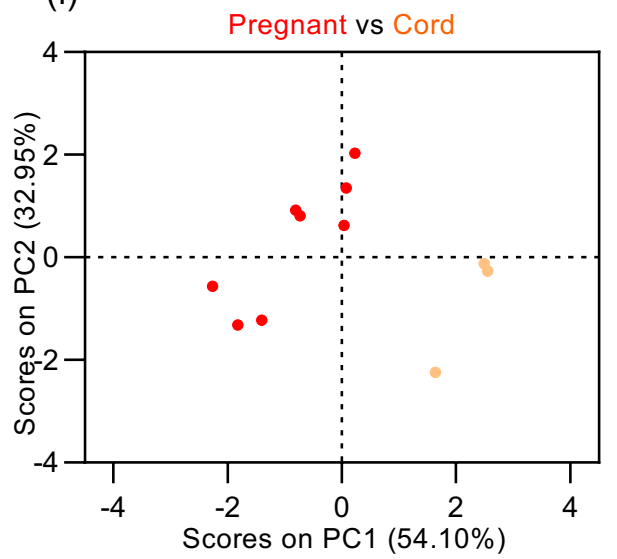

(ii)

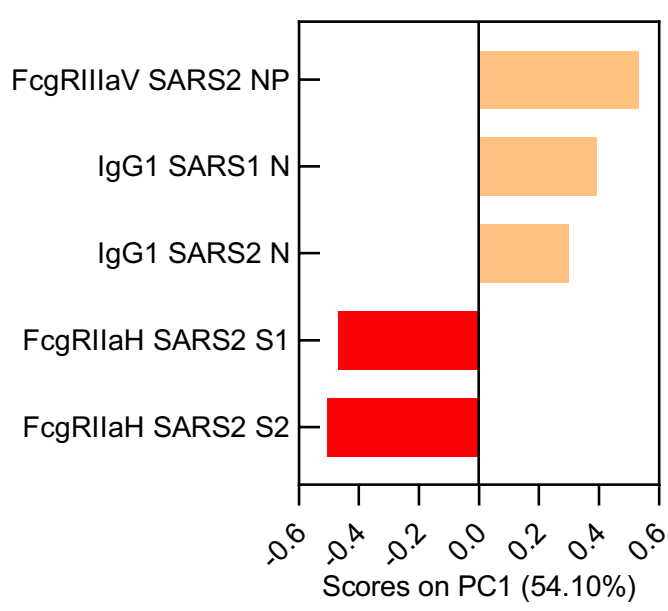



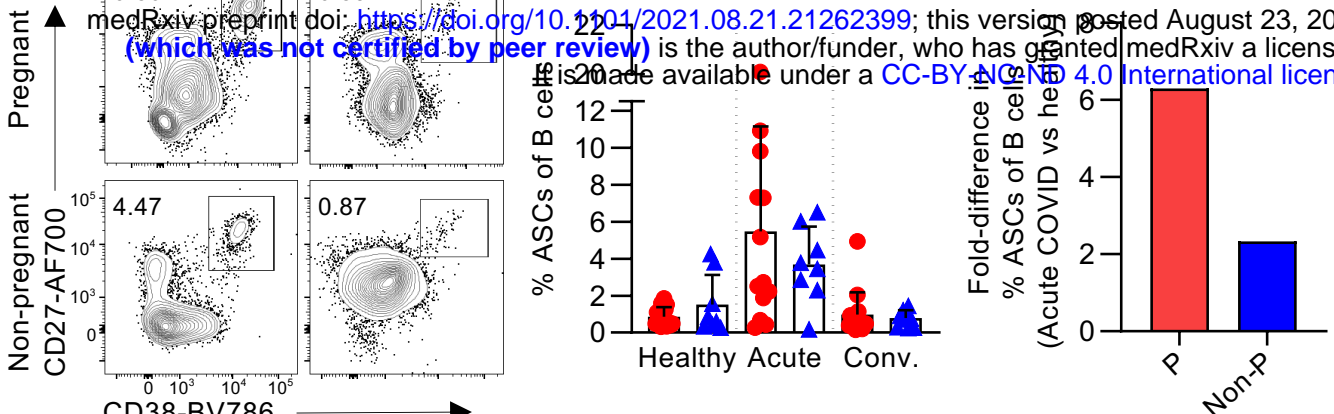

\section{政}
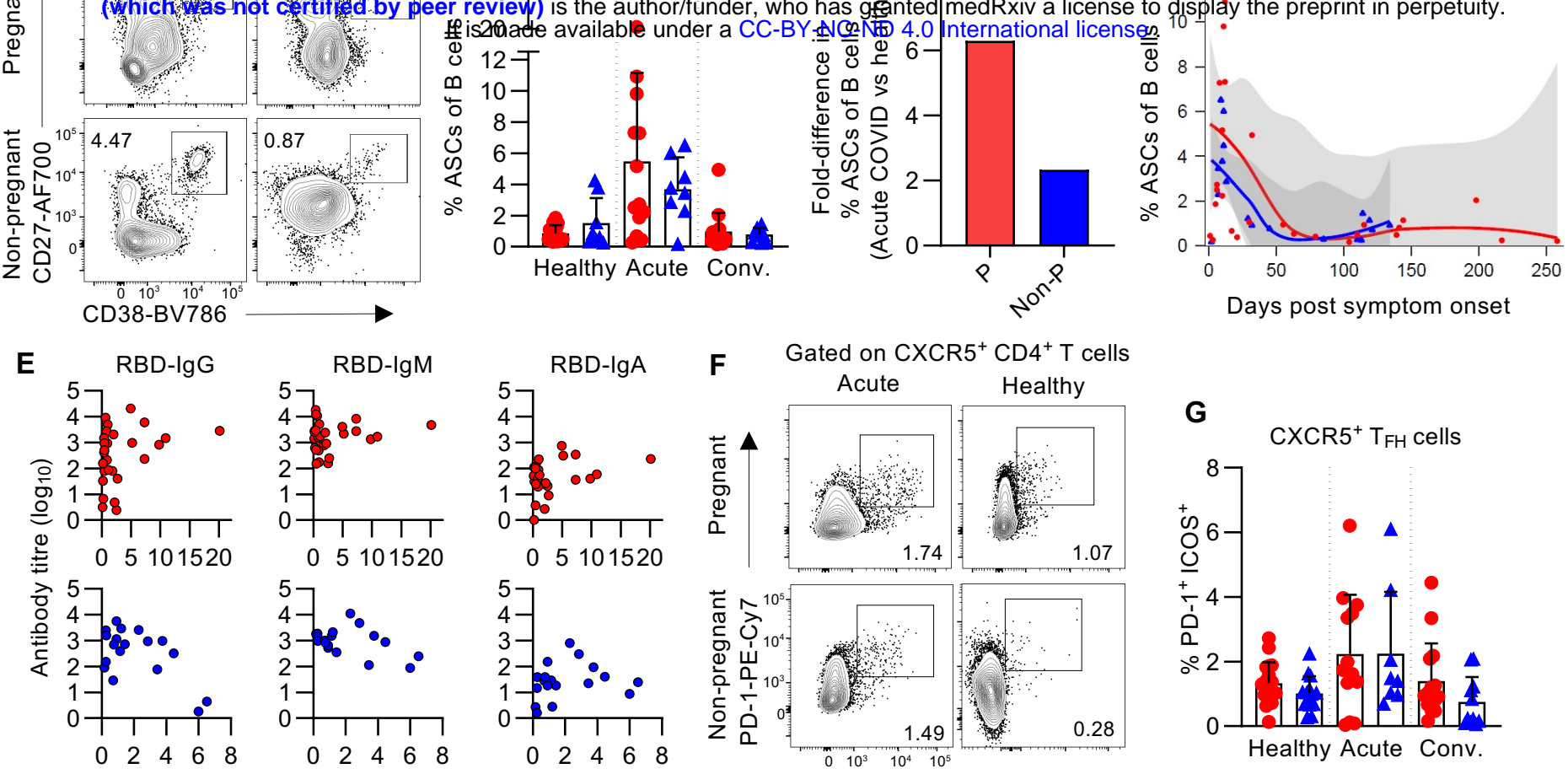

Gated on CXCR5 ${ }^{+} \mathrm{CD} 4^{+} \mathrm{T}$ cells
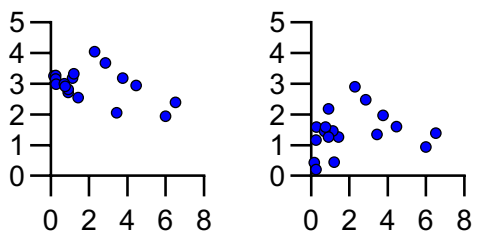

$\%$ ASCs of B cells

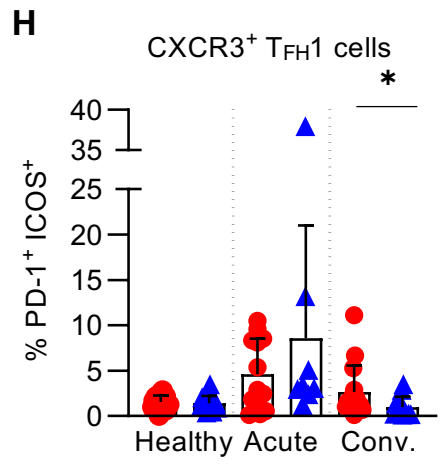

CXCR3- $^{-} \mathrm{T}_{\mathrm{FH}} 2 / 17$ cells
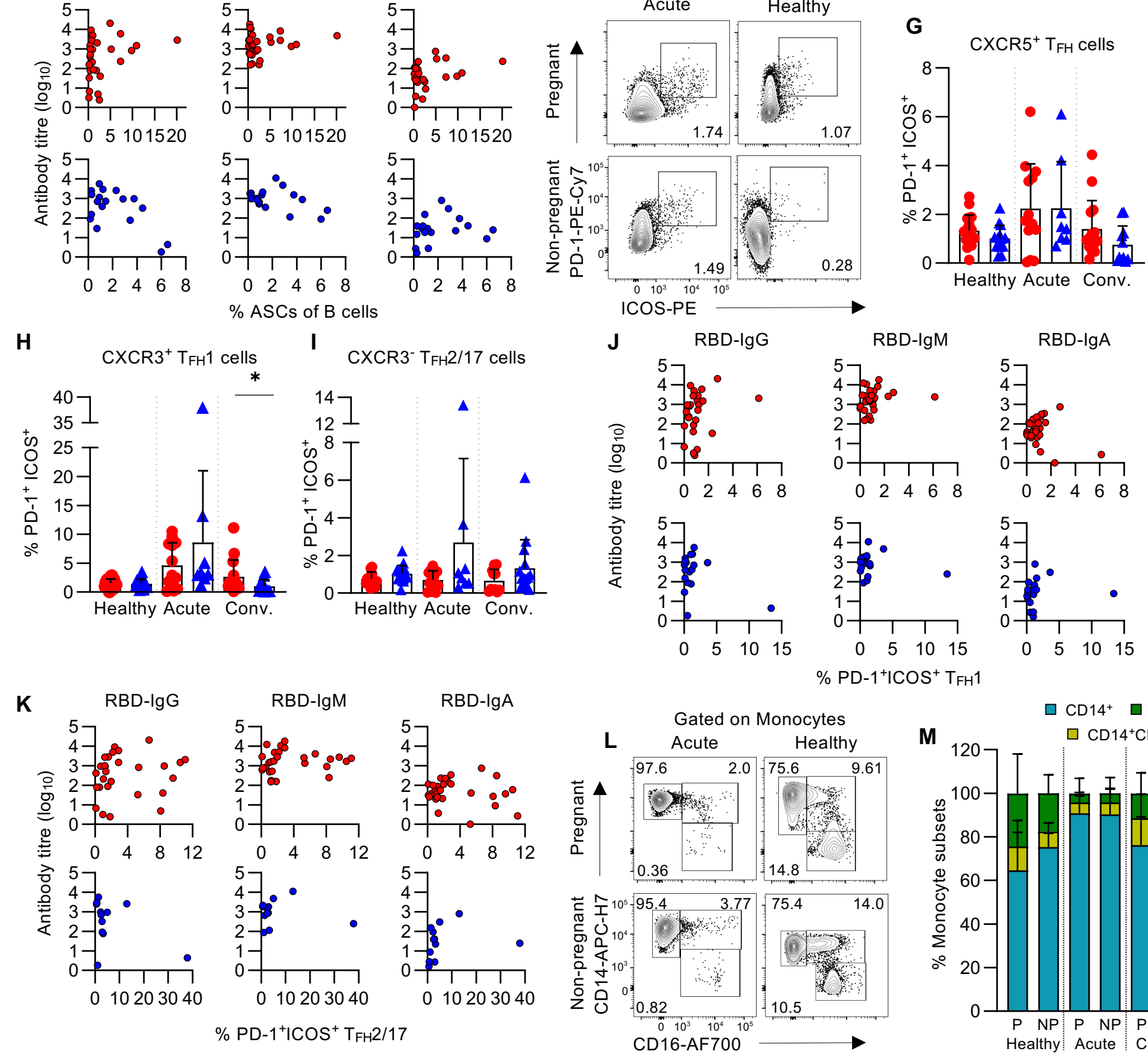

$\%$ PD- $1^{+} \mathrm{ICOS}^{+} \mathrm{T}_{\mathrm{FH}} 1$
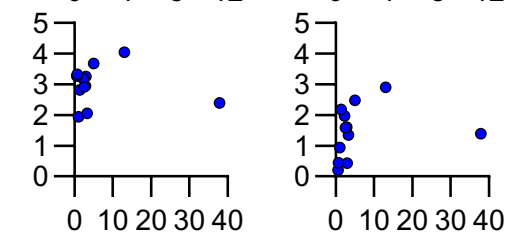

$\%$ PD $-1^{+}{ }^{+} \operatorname{COS}^{+} T_{F H} 2 / 17$

Figure 4 Habel et al.

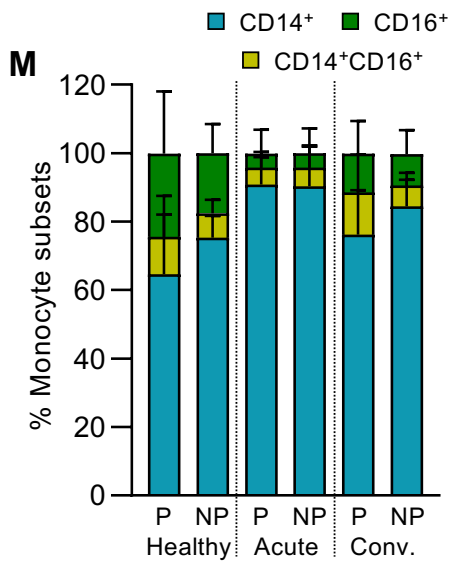


A Gated on NK cells

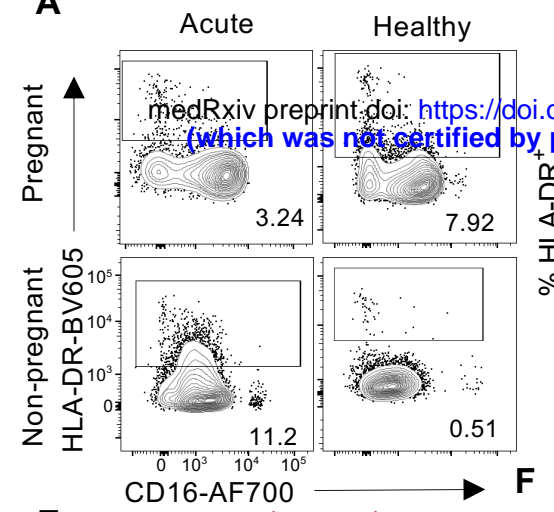

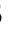

C

D

$457 \stackrel{* * * *}{*} \stackrel{\text { ॥ }}{\stackrel{*}{ \pm}} 307$

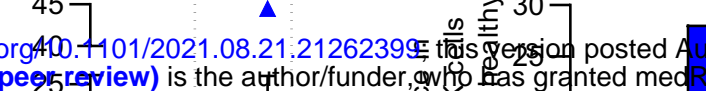
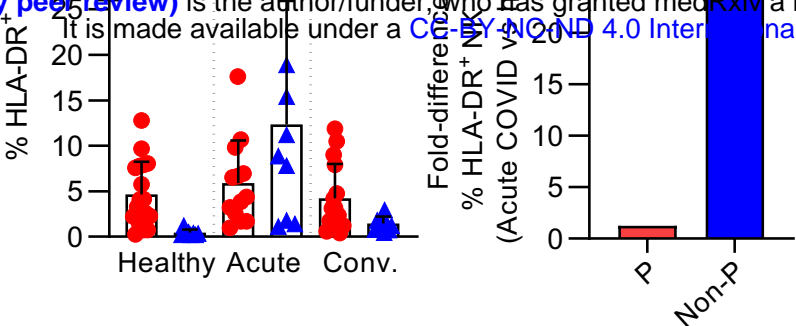

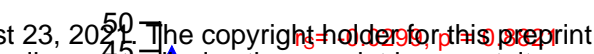

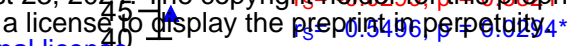
nal license.

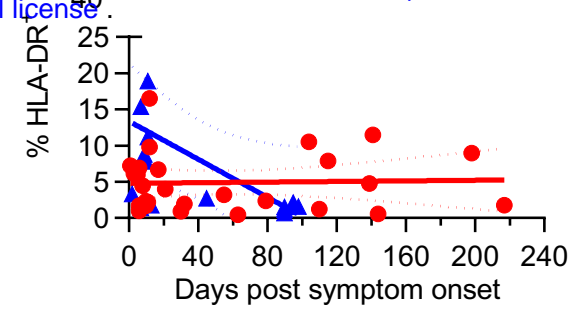

(i) $\quad \mathrm{CD} 56^{\mathrm{dim}} \mathrm{CD} 16^{+} \mathrm{NK}$ cells
- Pregnant $(\mathrm{P})$

- Non-pregnant (Non-P)
CD56 ${ }^{\text {bright }}$ CD16- $\mathrm{NK}$ cells

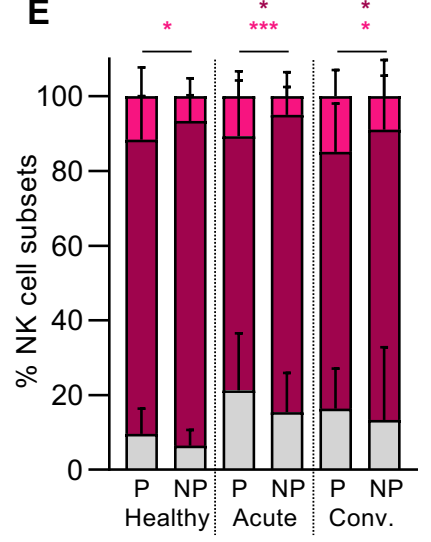

$\square$ CD56 brightCD16- $\square$ CD56 ${ }^{\text {dim CD16 }}{ }^{+}$

$\square$ Non-CD56 bright/dim
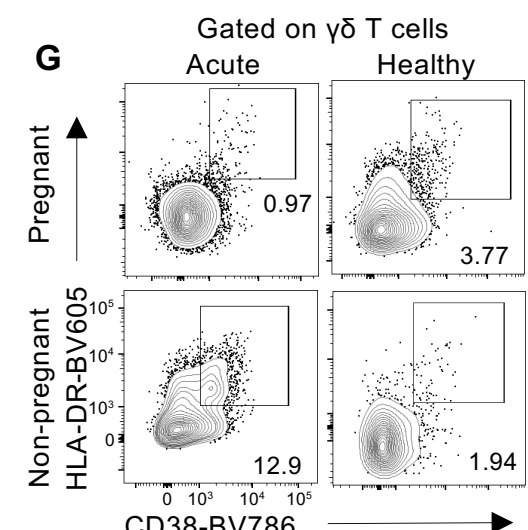

K
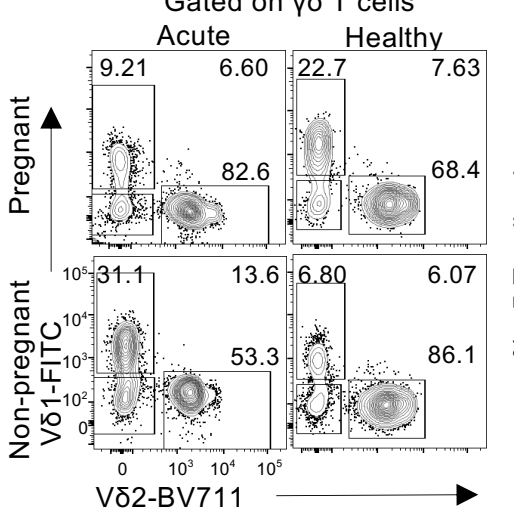

n

Gated on MR1 ${ }^{+} \mathrm{V} \alpha 7.2^{+} \mathrm{MAIT}$ cells

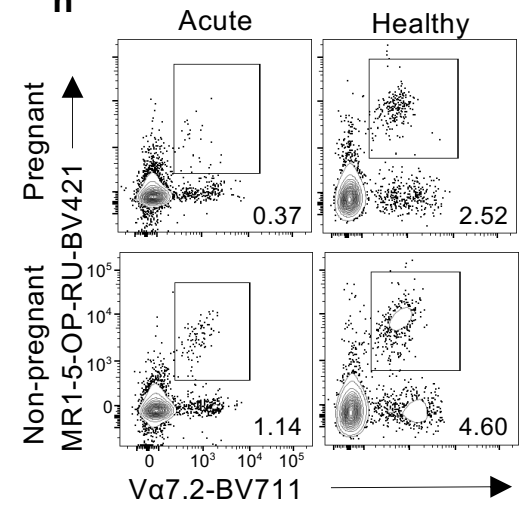

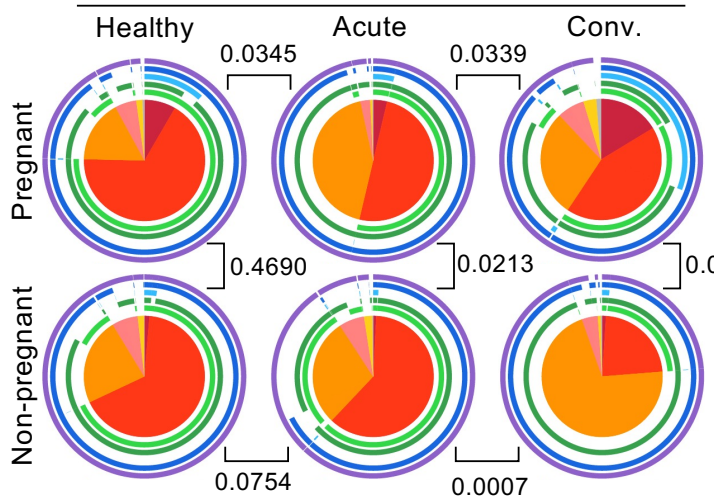

\# cytotoxic molecules

$\square 5 \square 4 \square 3$

$\square 2 \square 1 \square 0$

I

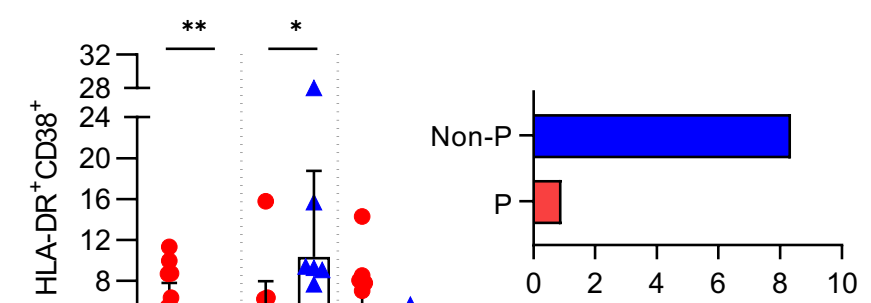

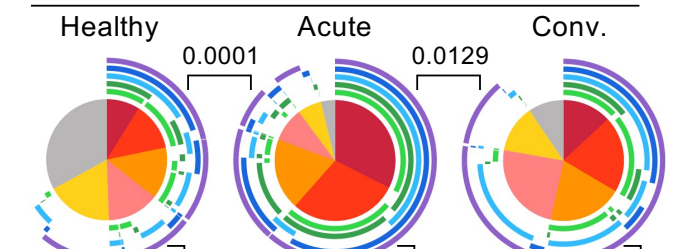

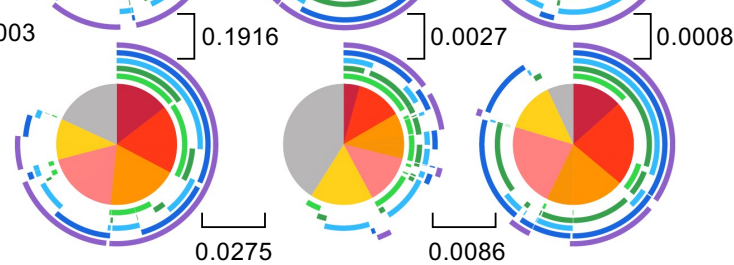

cytotoxic molecule

$\square$ Granzyme A $\square$ Granzyme B $\square$ Granzyme K

$\square$ Granzyme M $\square$ Perforin

M
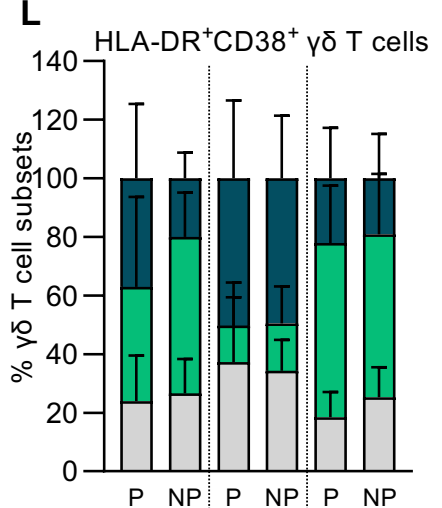

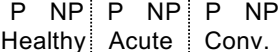

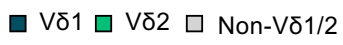

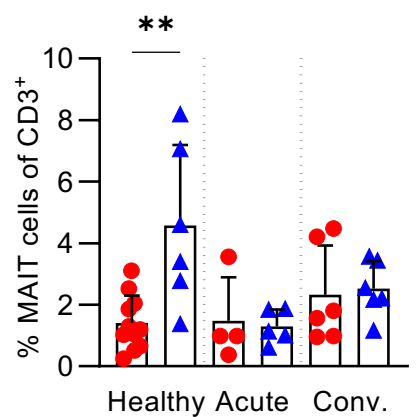

Fold-difference in

$\%$ HLA-DR ${ }^{+}$CD $38^{+} \gamma \delta$ T cells

(Acute COVID vs healthy)

(i) $r_{S}=-0.5671, p=0.0922$

$1007 r_{s}=-0.6364, p=0.0402^{*}$
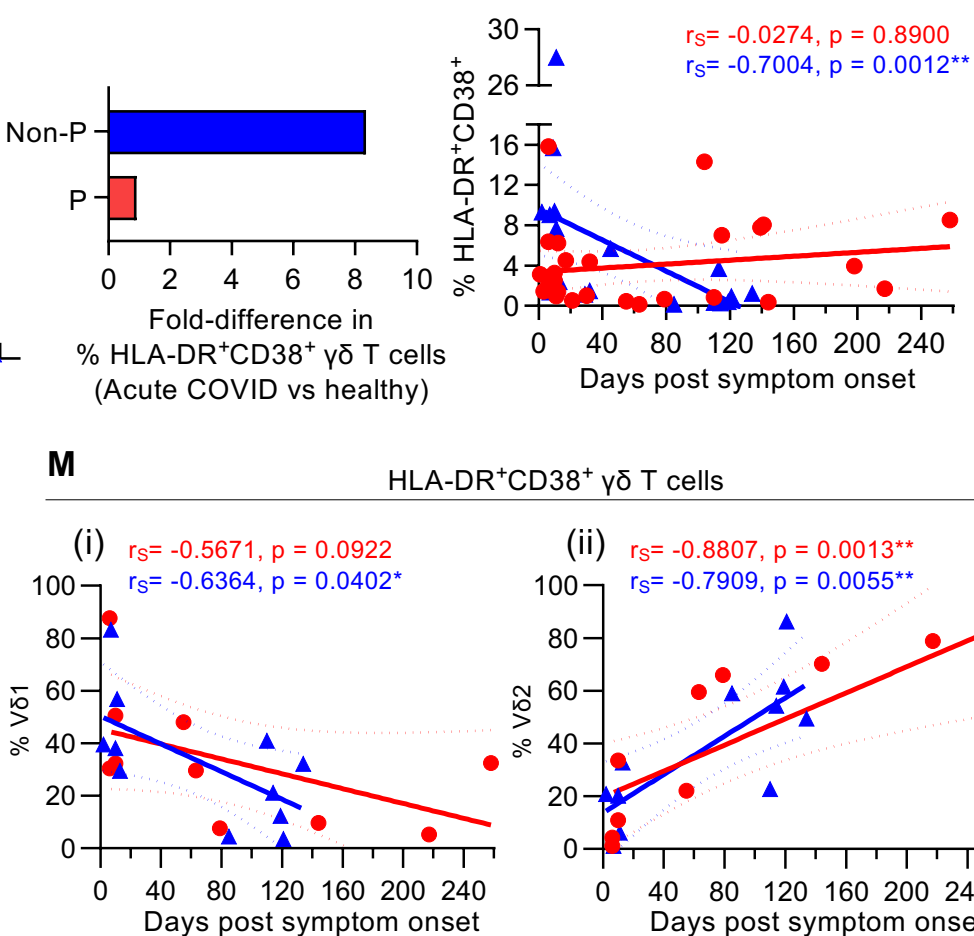

HLA-DR ${ }^{+} \mathrm{CD} 38^{+}$y $\delta \mathrm{T}$ cells

(ii) $r_{S}=-0.8807, p=0.0013^{* *}$

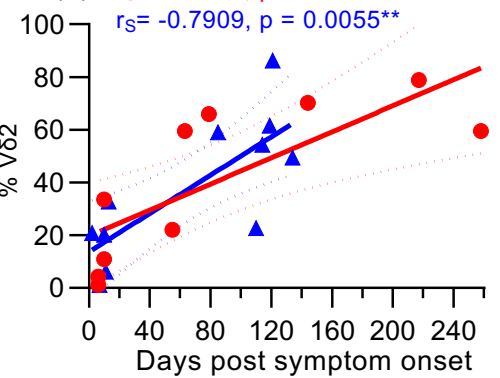

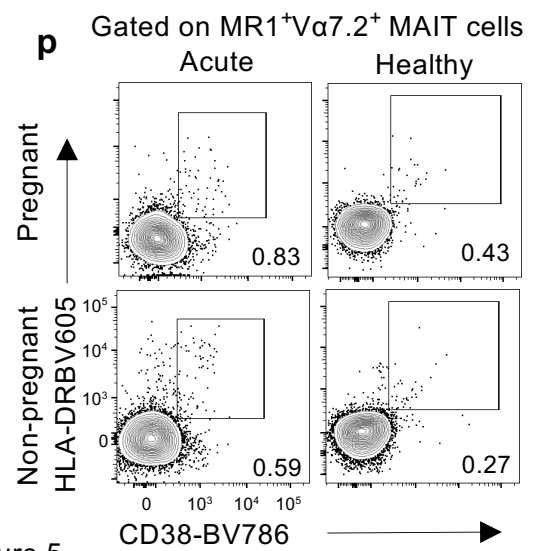

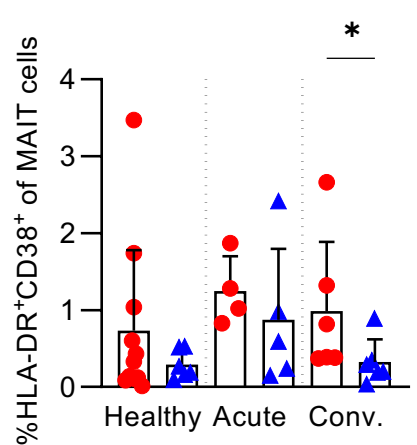

Habel et al. 


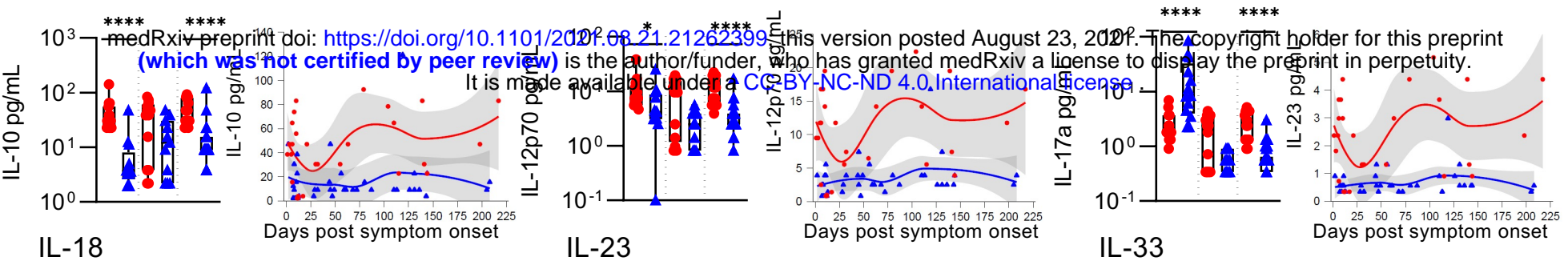

$* * * * \quad * * * *$
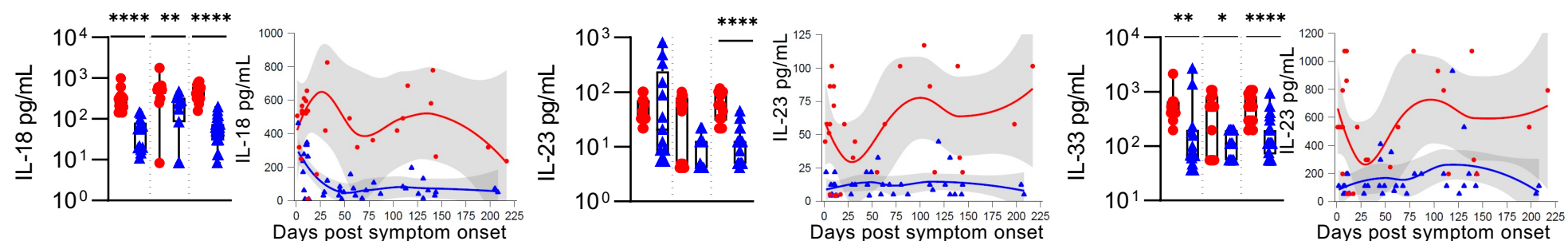

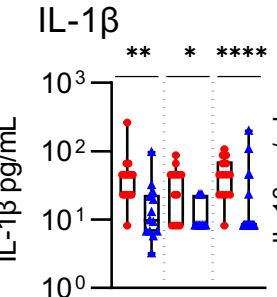

TNF- $\alpha$

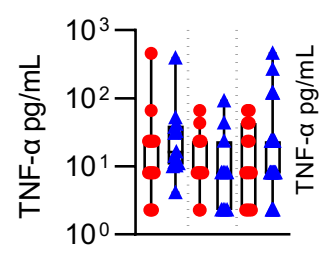

IL-8
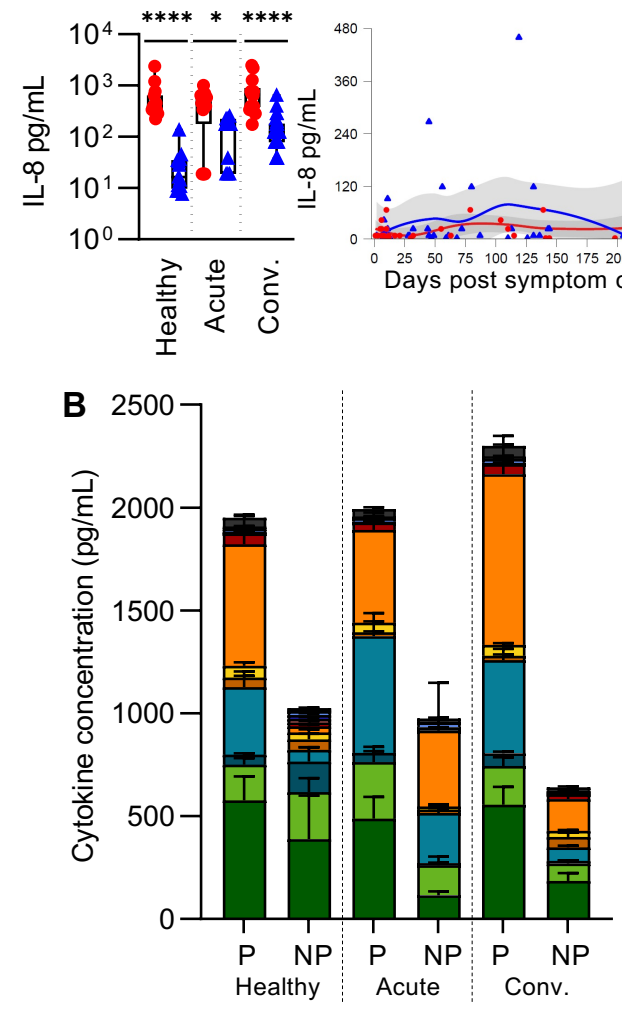

Figure 6

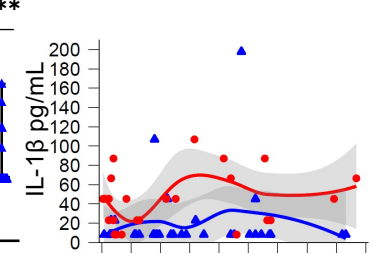

$0 \quad 255075100125150175200225$
Days post symptom onset

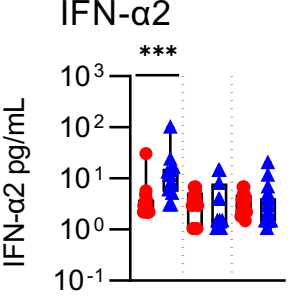

MCP-1

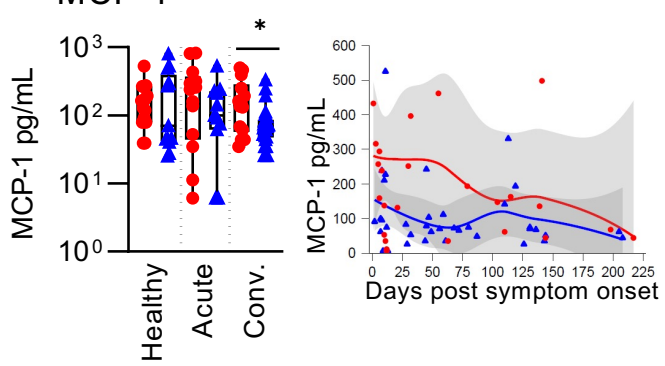

- Pregnant (P)

\ Non-pregnant (Non-P)

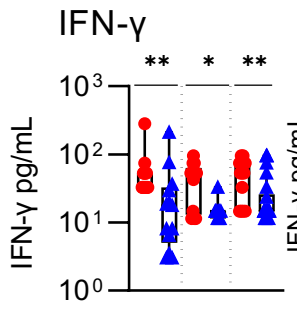

IL-6

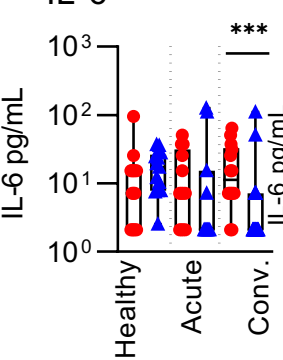

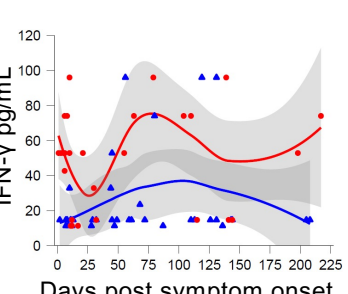

Days post symptom onset

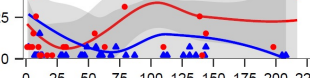

Days post symptom onset

Cytokine/chemokine

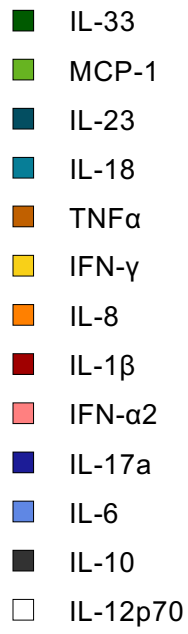

口 IL-33

口 IL-23

口 IL-18

$\square \quad$ TNFa

$\square \quad \mathrm{IFN}-\mathrm{Y}$

$\square \quad \mathrm{IL}-8$

- IL-1 $\beta$

$\square \quad$ IFN- $\alpha 2$

- IL-17a

IL-12p70
C
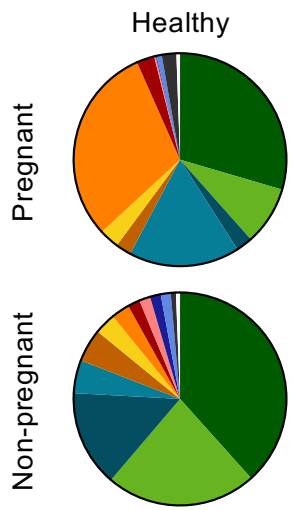

Acute
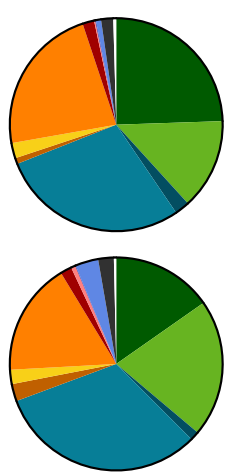

Conv.

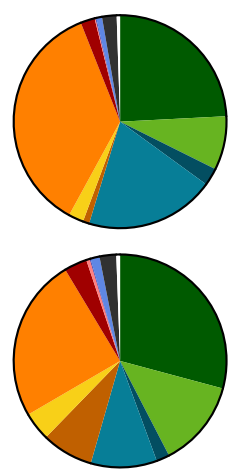




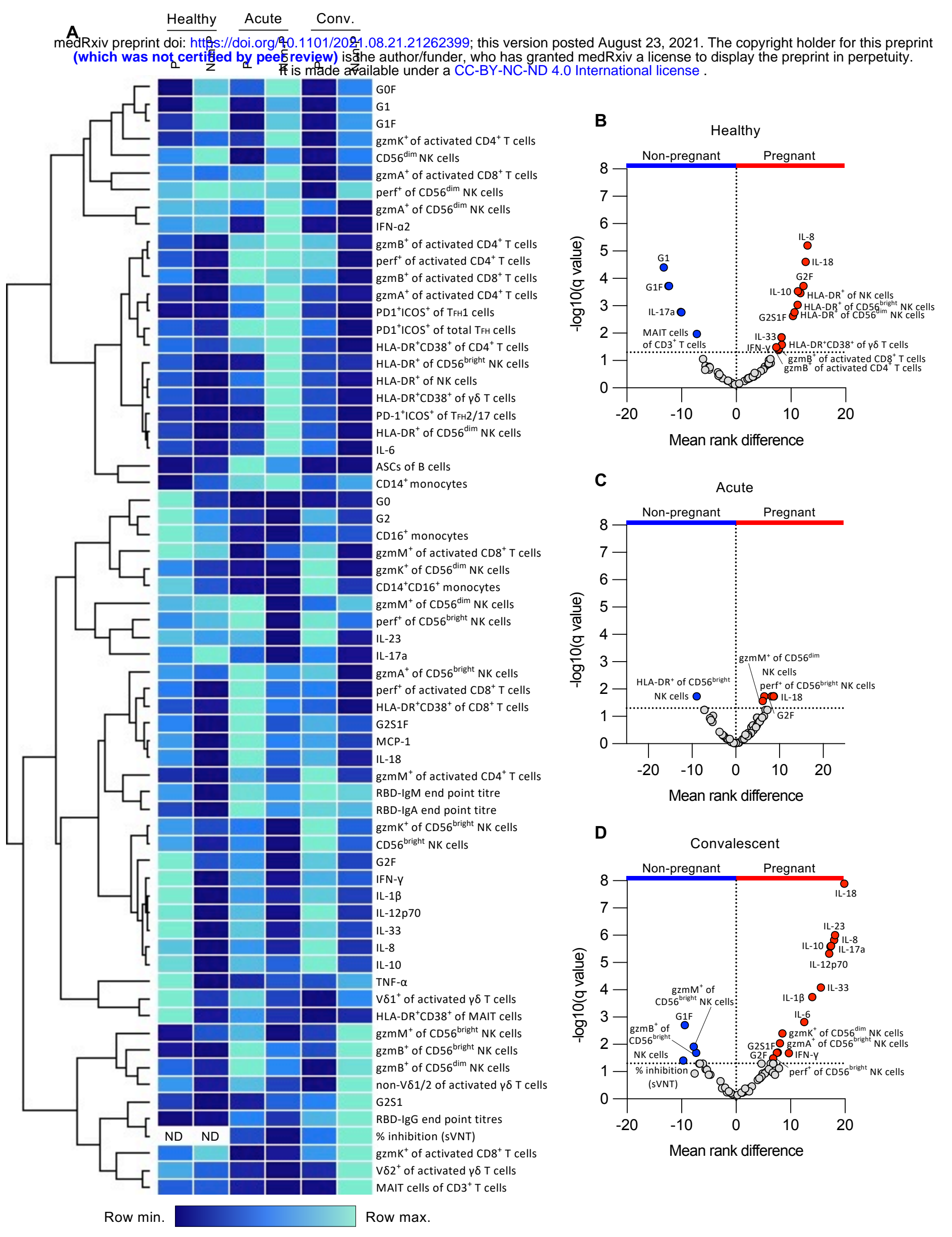

Figure 7

Habel et al. 
RBD-lgA

medRxiv pre*trint doi: https://doi.org/10.1101/2021.08.21.21262399; this version posted August 23, 2021. The copyright holder for this preprint 을 Phich was not certified gy peer review) is the author/funder, who has granted medRxiv a license to display the preprint in perpetuity.

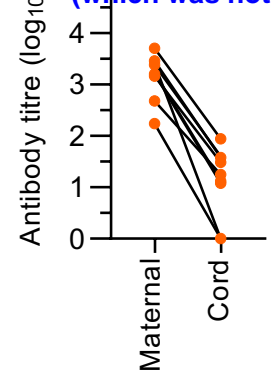

B

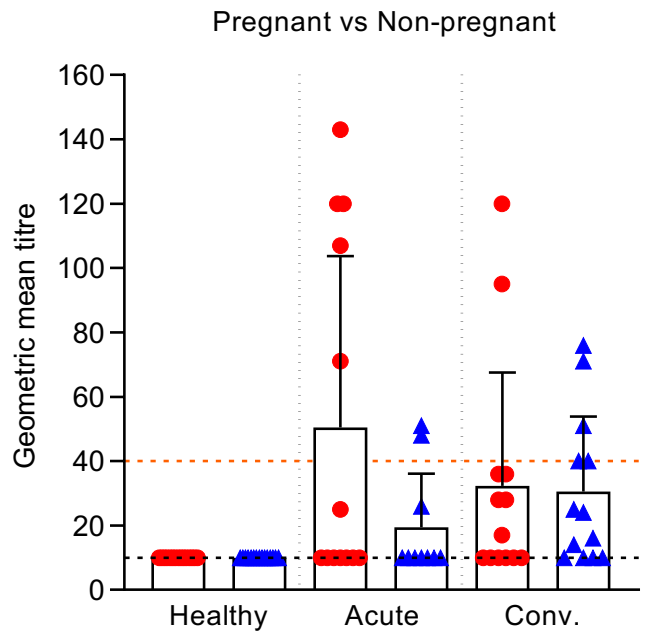

C

$\Delta$ Non-pregnant (Non-P)

- COVID-19 pregnancy

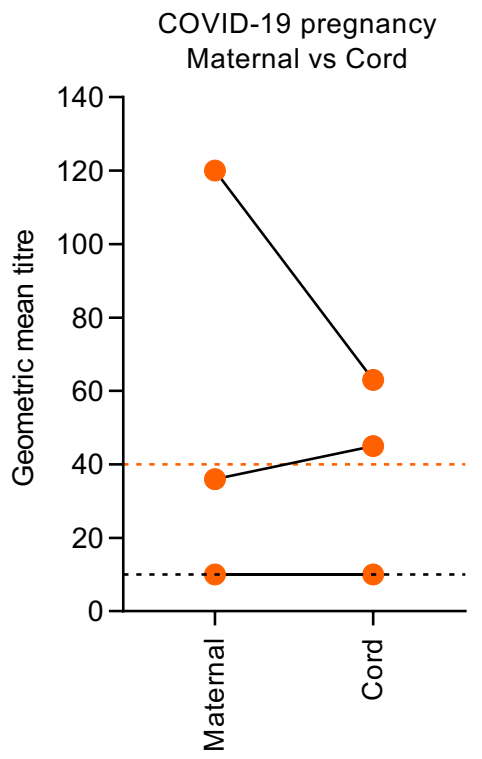

Supplementary Figure 1 Habel et al. 
medRxiy preprint doi: https://doi.org/10. 13101/2021.08.21.21262399; this versior8pested August 23, 2021. The copyrigstot holder for this preprint
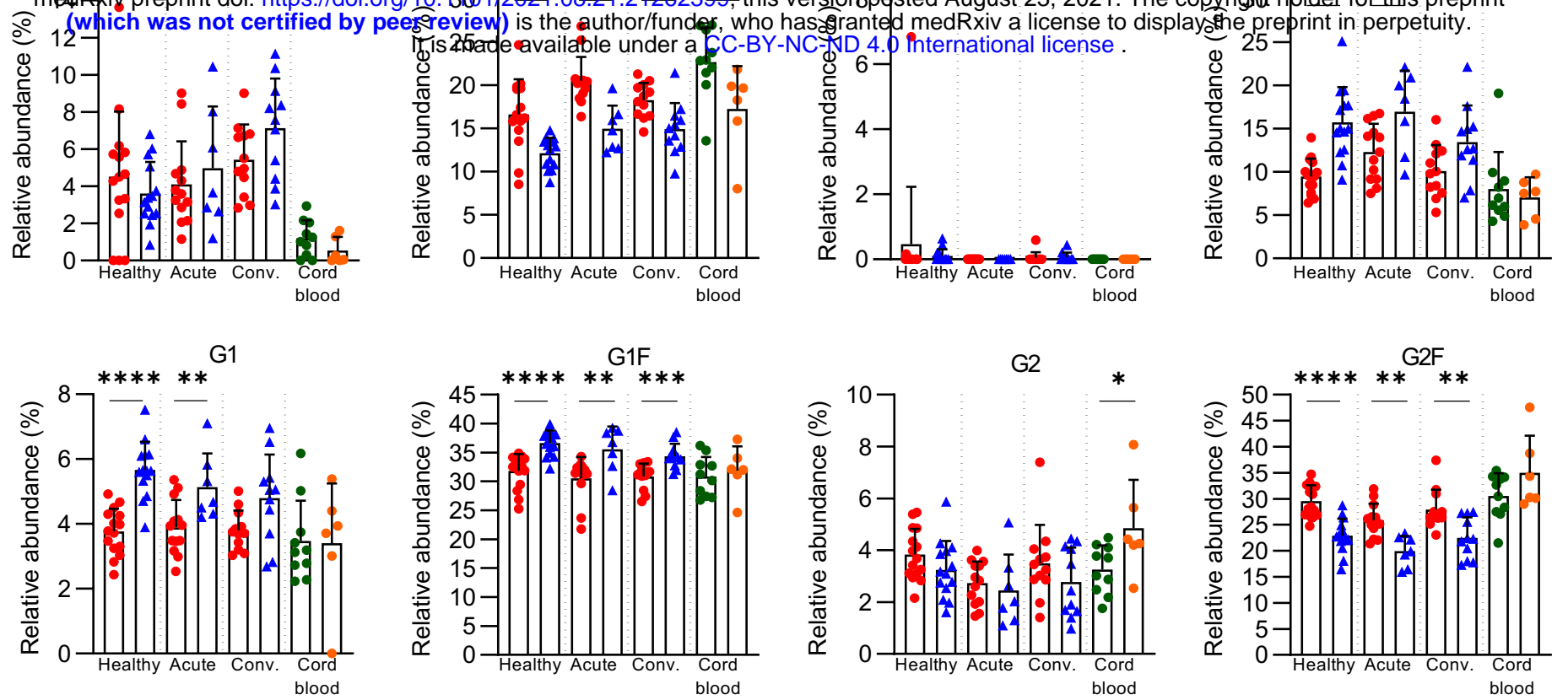

B

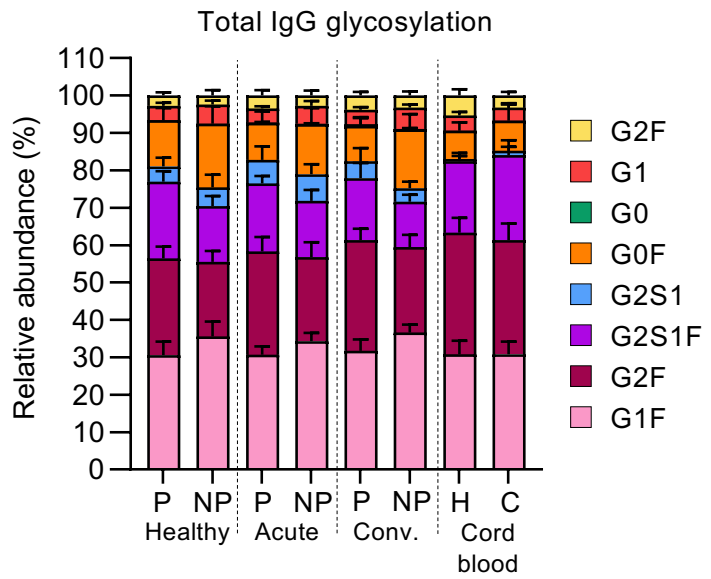

$G=$ galactose

$\mathrm{S}=$ sialic acid

$F=$ fucose

$2=$ glycan at 2 sites

$1=$ glycan at 1 site

$0=$ glycan not present
- Pregnant $(\mathrm{P})$

- Non-pregnant (Non-P)

- Unexposed pregnancy

- COVID-19 pregnancy

Supplementary Figure 2 Habel et al. 

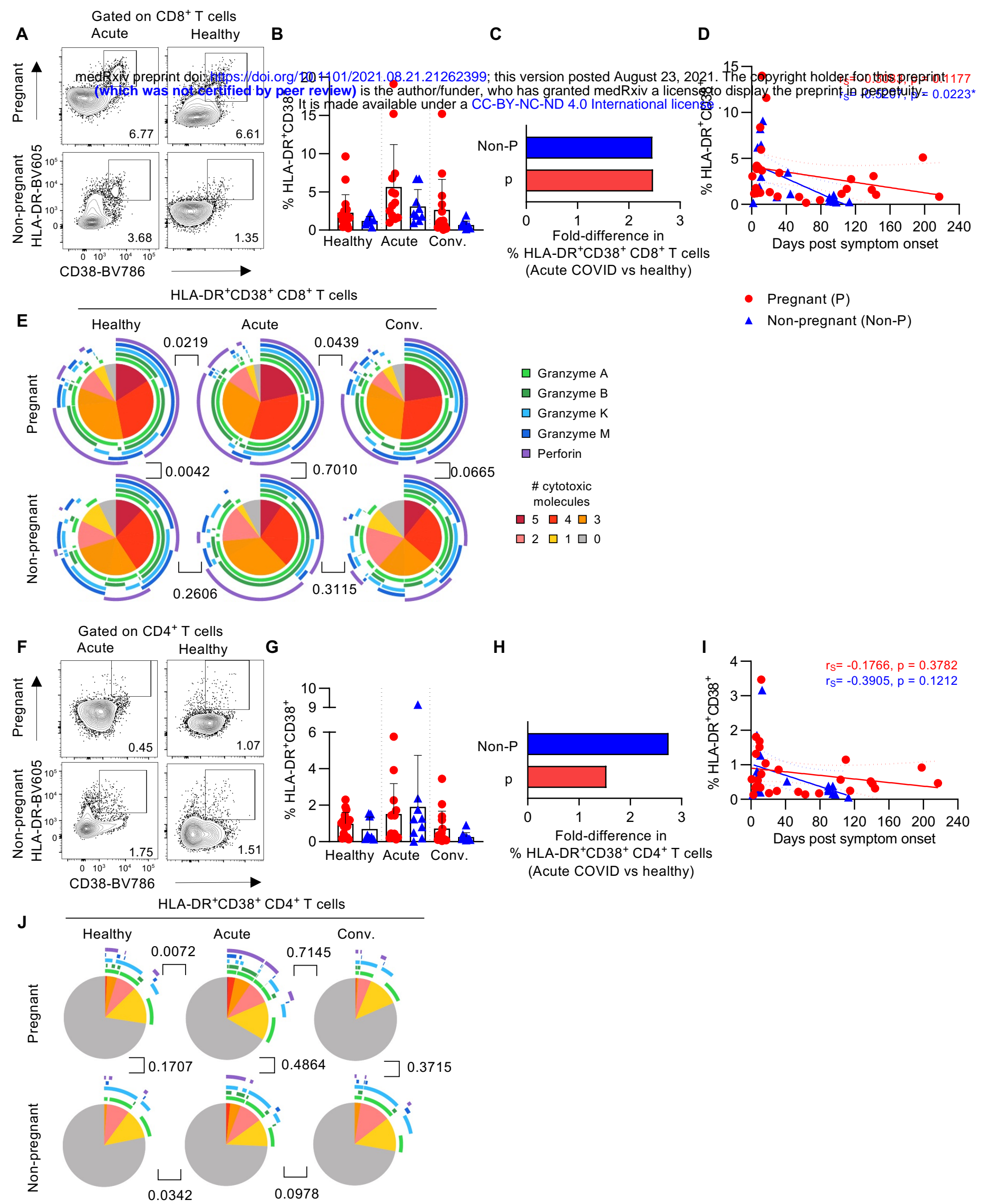

H

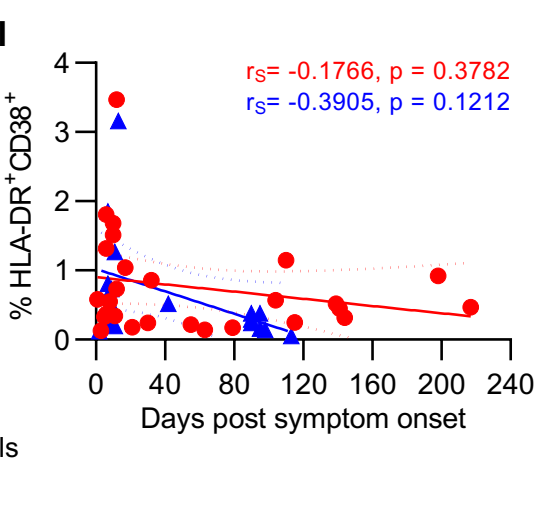

Supplementary Figure 3

Habel et al. 

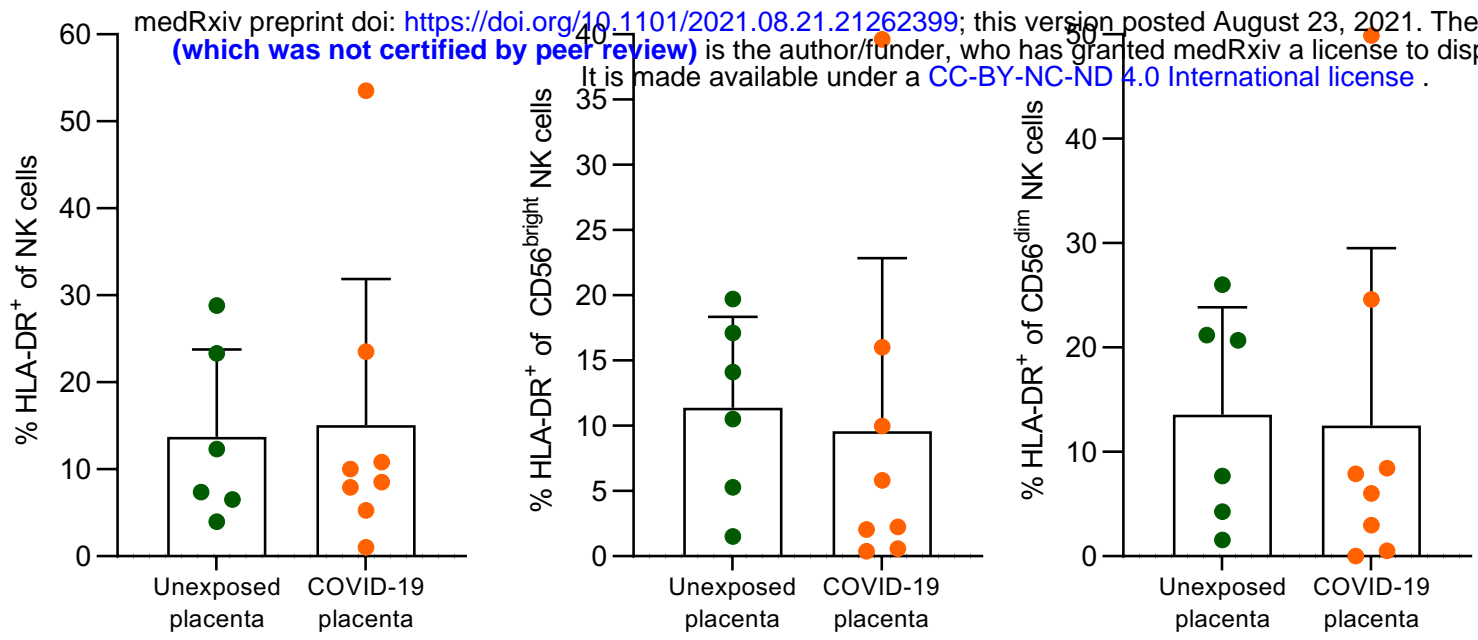

D

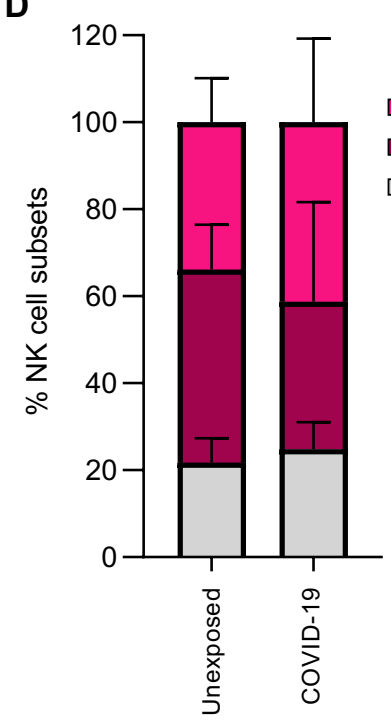

F

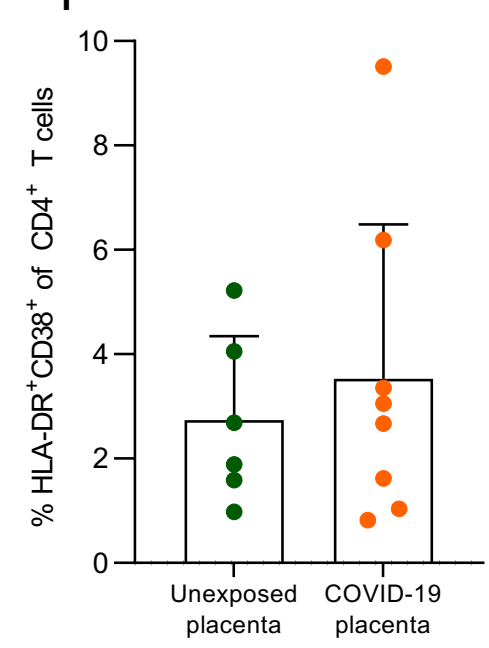

Supplementary Figure 4
E

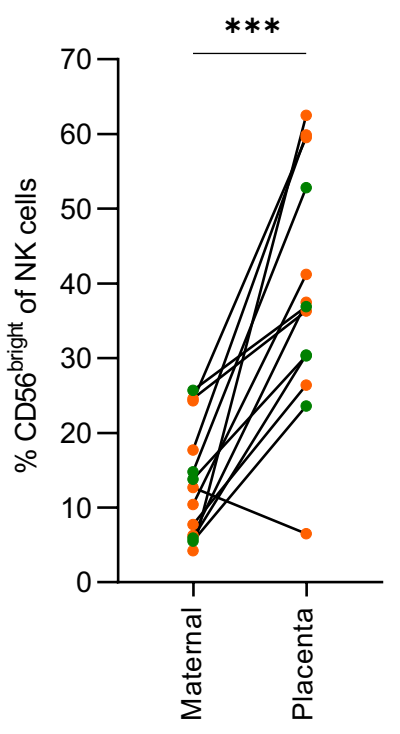

- COVID-19 pregnancy

- Unexposed pregnancy

\section{CD56 dim}

$\square$ Non-CD56 bright/dim

G

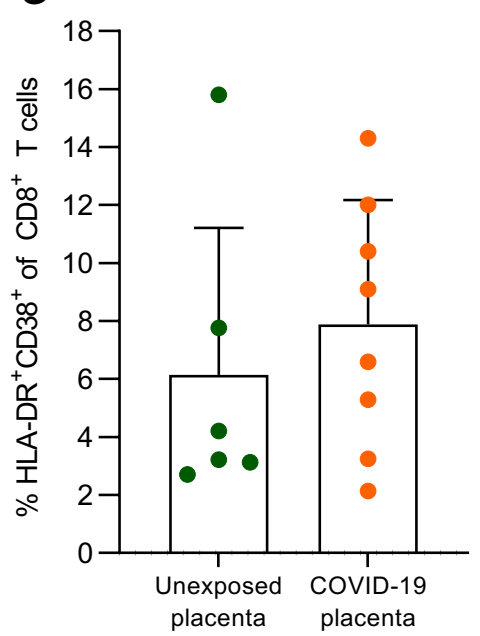

H

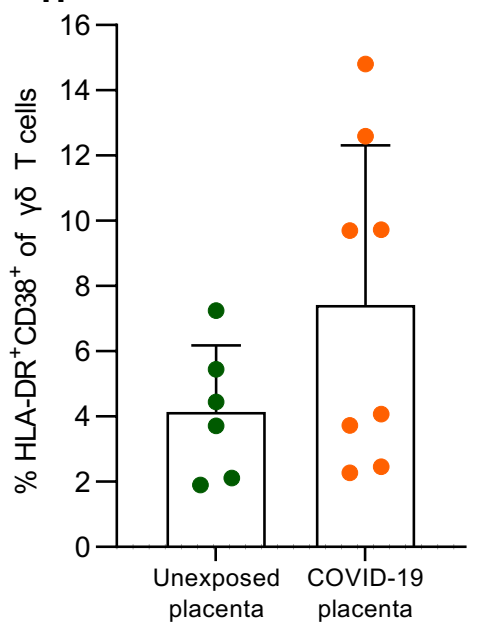

Habel et al. 
medRxiv preprint doi: https://doi.org/10.1101/2021.08.21.21262399; this version posted August 23, 2021. The copyright holder for this preprint (which was not certified by peer review) is the author/funder, who has granted medRxiv a license to display the preprint in perpetuity. It is made available under a CC-BY-NC-ND 4.0 International license.
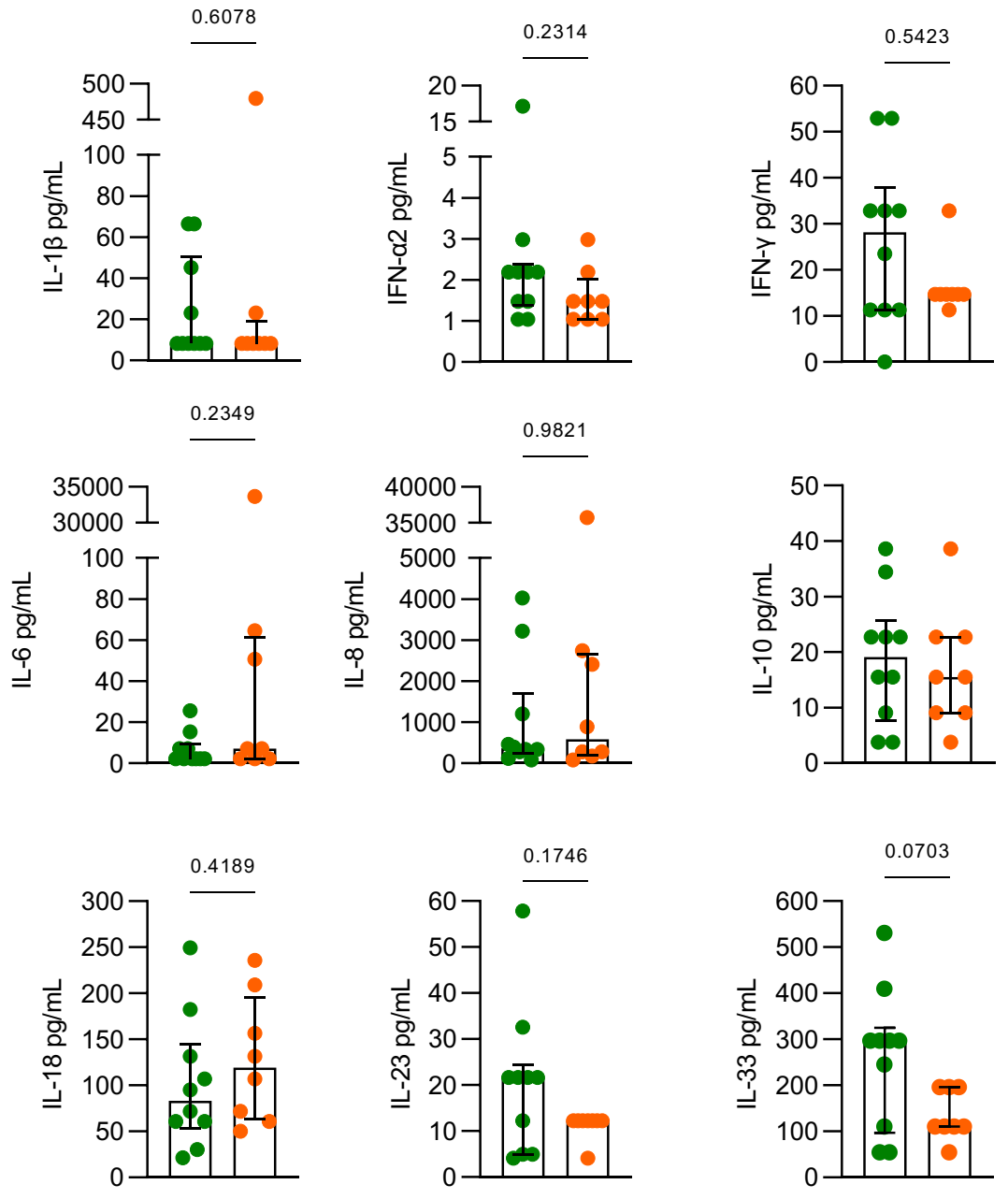
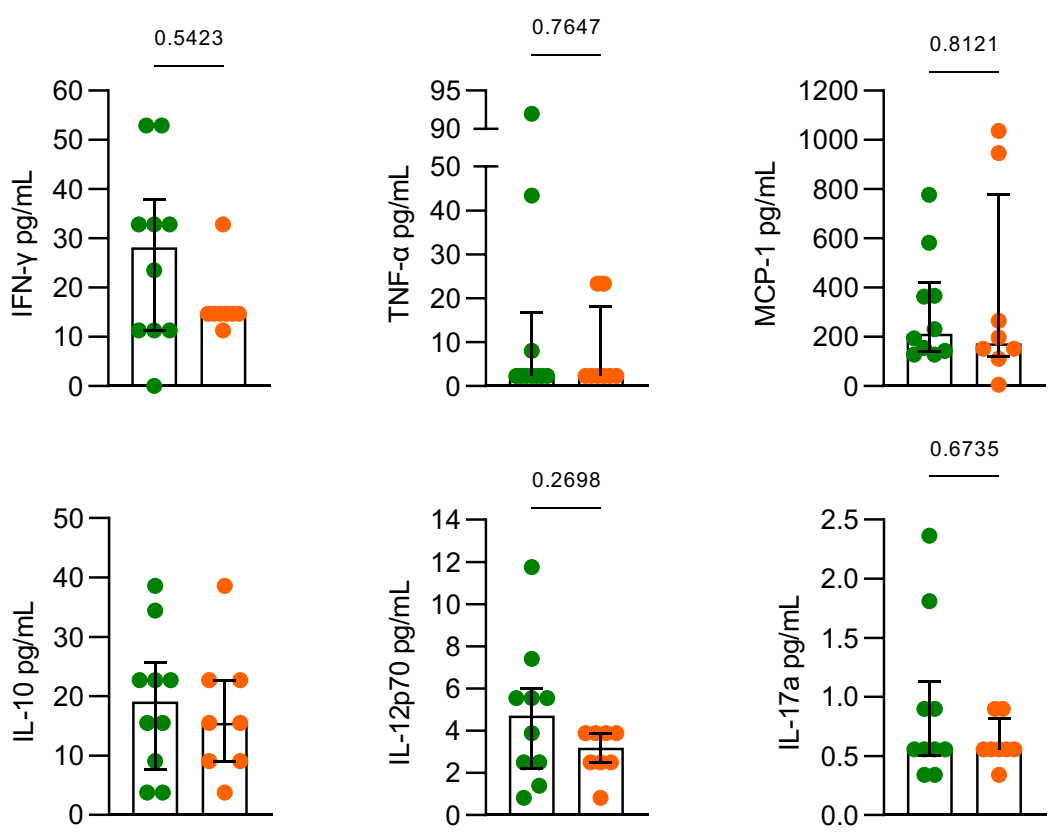

- COVID-19 pregnancy 
A

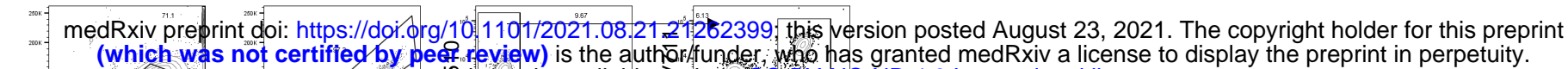
ar:
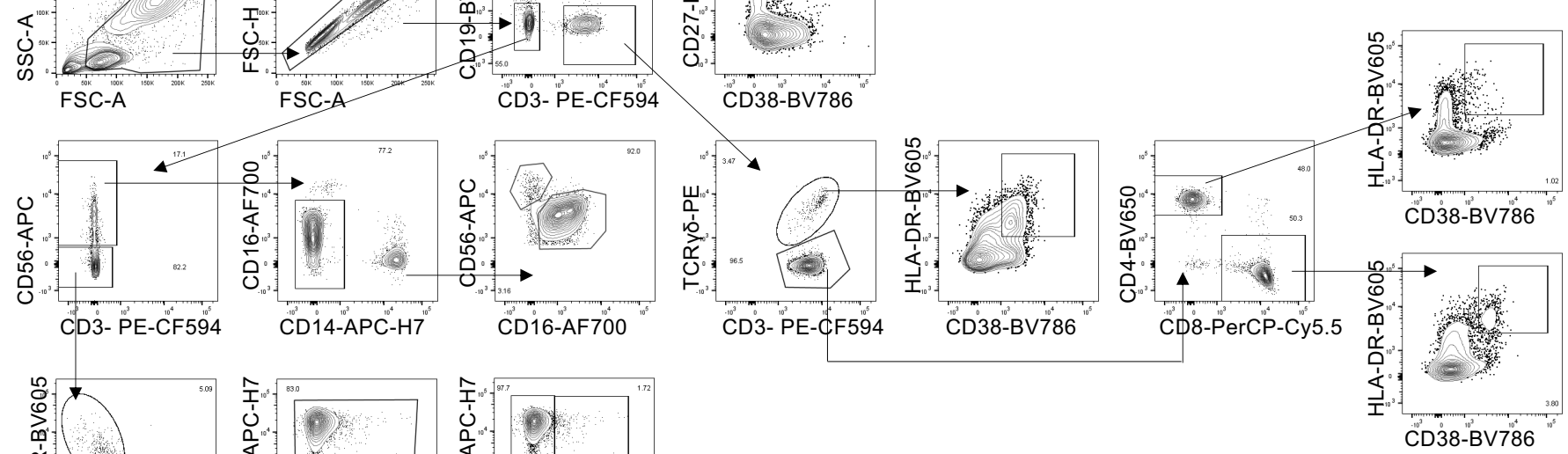

B

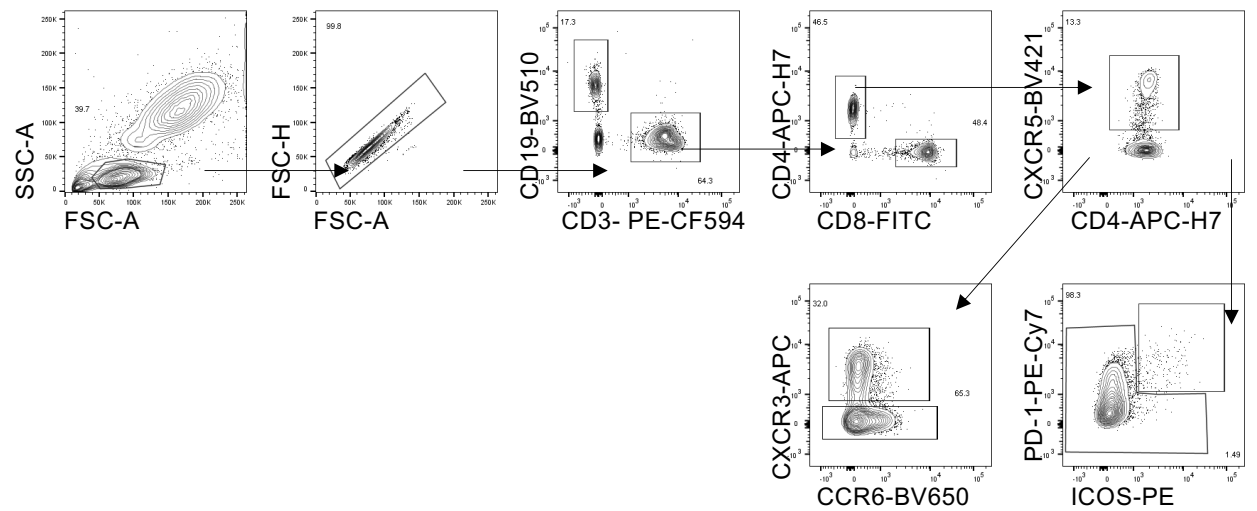

Supplementary Figure 6

Habel et al. 
A

全

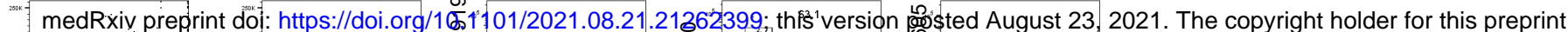
(which was not certified by peer Eevíw'w) is the author/dinder who has granted medRxiv a license to display the preprint in perpetuity.

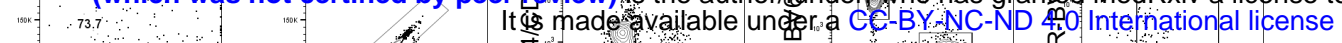
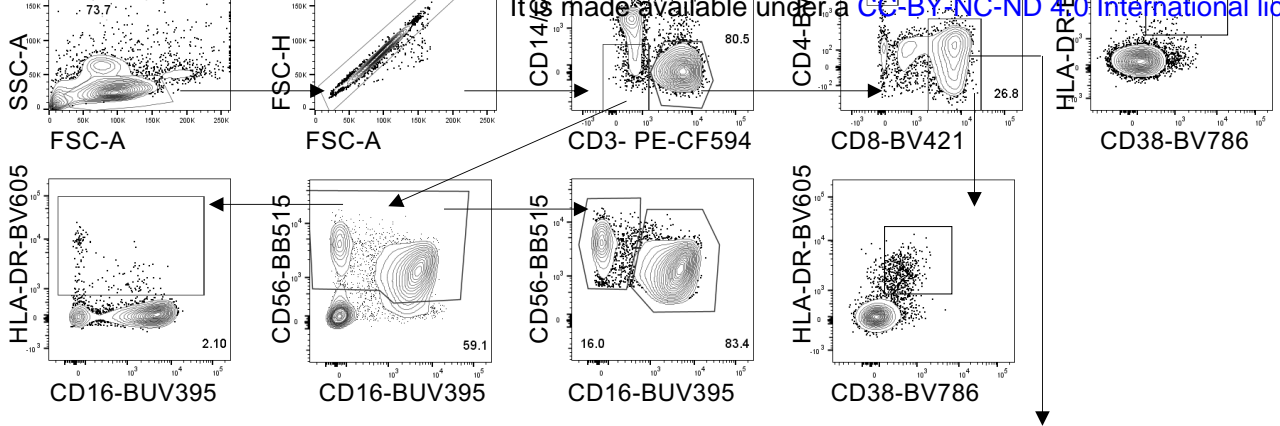

Granzyme and perforin Boolean gating of $\mathrm{CD} 8^{+} \mathrm{T}$ cells
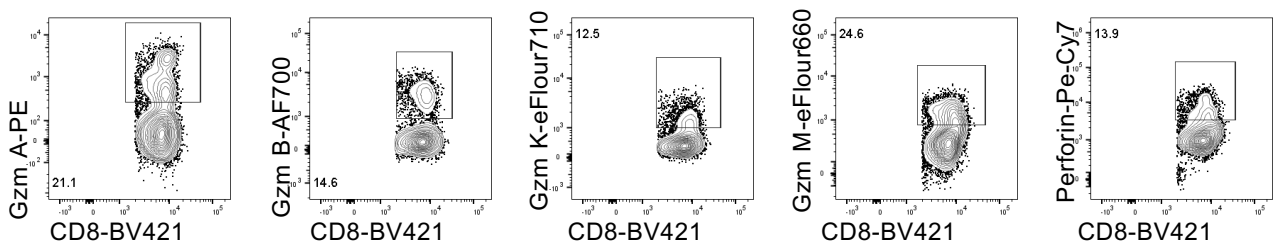

B
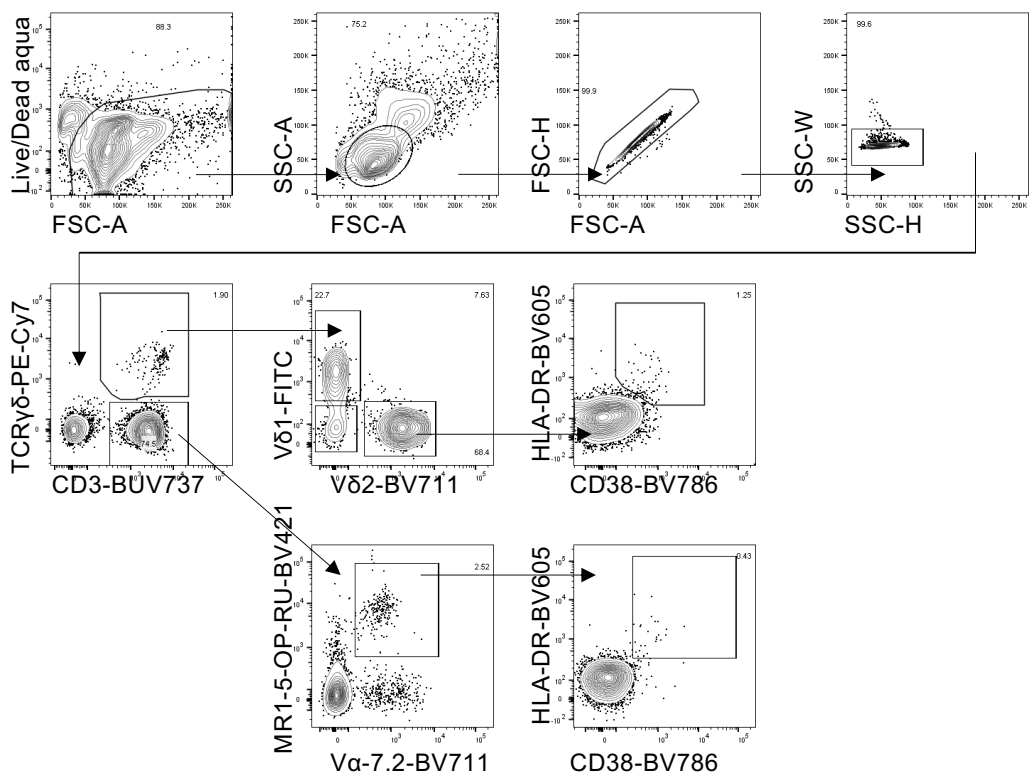